\title{
Targeting oncomiRNAs and mimicking tumor suppressor miRNAs: New trends in the development of miRNA therapeutic strategies in oncology (Review)
}

\author{
ROBERTO GAMBARI $^{1}$, ELEONORA BROGNARA ${ }^{1}$, DEMETRIOS A. SPANDIDOS $^{2}$ and ENRICA FABBRI ${ }^{1}$ \\ ${ }^{1}$ Department of Life Sciences and Biotechnology and Biotechnology Center, Ferrara University, Ferrara, Italy; \\ ${ }^{2}$ Laboratory of Clinical Virology, University of Crete School of Medicine, Heraklion, Crete, Greece
}

Received March 9, 2016; Accepted April 29, 2016

DOI: $10.3892 /$ ijo.2016.3503

\begin{abstract}
MicroRNA (miRNA or miR) therapeutics in cancer are based on targeting or mimicking miRNAs involved in cancer onset, progression, angiogenesis, epithelial-mesenchymal transition and metastasis. Several studies conclusively have demonstrated that miRNAs are deeply involved in tumor onset and progression, either behaving as tumor-promoting miRNAs (oncomiRNAs and metastamiRNAs) or as tumor suppressor miRNAs. This review focuses on the most promising examples potentially leading to the development of anticancer, miRNAbased therapeutic protocols. The inhibition of miRNA activity can be readily achieved by the use of miRNA inhibitors and oligomers, including RNA, DNA and DNA analogues (miRNA antisense therapy), small molecule inhibitors, miRNA sponges or through miRNA masking. On the contrary, the enhancement of miRNA function (miRNA replacement therapy) can be achieved by the use of modified miRNA mimetics, such as plasmid or lentiviral vectors carrying miRNA sequences. Combination strategies have been recently developed based on the observation that i) the combined administration of different antagomiR molecules induces greater antitumor effects and ii) some anti-miR molecules can sensitize drug-resistant tumor cell lines to therapeutic drugs. In this review, we discuss two additional issues: i) the combination of miRNA replacement
\end{abstract}

Correspondence to: Professor Roberto Gambari, Department of Life Sciences and Biotechnology and Biotechnology Center, Ferrara University, Via Fossato di Mortara 74, I-44121 Ferrara, Italy

E-mail:gam@unife.it

Abbreviations: miRNAs or miRs, microRNAs; PNA, peptide nucleic acids; CTCs, circulating tumor cells; EMT, epithelial-mesenchymal transition; MET, mesenchymal-epithelial transition; CML, chronic myelogenous leukemia; CRC, colorectal carcinoma

Key words: microRNAs, peptide nucleic acids, miRNA replacement therapy, antagomiR, epithelial-mesenchymal transition, metastasis, miR-124 therapy with drug administration and ii) the combination of antagomiR and miRNA replacement therapy. One of the solid results emerging from different independent studies is that miRNA replacement therapy can enhance the antitumor effects of the antitumor drugs. The second important conclusion of the reviewed studies is that the combination of anti-miRNA and miRNA replacement strategies may lead to excellent results, in terms of antitumor effects.

\section{Contents}

1. Introduction

2. Tumor suppressor miRNAs

3. OncomiRNAs and metastamiRNAs

4. Mimicking tumor suppressor miRNAs in miRNA replacement therapy

5. Targeting oncomiRNAs

6. MicroRNAs and epithelial-mesenchymal transition

7. MicroRNAs and neoangiogenesis

8. Selected examples of miRNA therapeutics: mimicking miR-124

9. Selected examples of miRNA therapeutics: mimicking miR-93

10. Selected examples of anti-miRNA therapeutics: targeting miR-221/222

11. Combined treatments: targeting multiple miRNAs

12. Combined treatments: co-administration of antitumor drugs and miRNA therapeutic agents

13. Combining miRNA replacement strategies with anti-miRNAs and siRNA molecules

14. Conclusion

\section{Introduction}

MicroRNAs (miRNAs or miRs) are a family of small (19-25 nucleotides in length) non-coding RNAs that have a key role in the regulation of gene expression through the inhibition or the reduction of protein synthesis following mRNA complementary sequence base pairing (1-4). A single or multiple mRNAs can be targeted at the $3^{\prime}$ untranslated region (3'UTR), 
coding sequence (CDS) or 5' untranslated region (5'UTR) sequence, and it is calculated that $>60 \%$ of human mRNAs are recognized by miRNAs (1-4). The miRNA/mRNA interaction occurs at the level of the RNA-induced silencing complex (RISC) and causes translational repression or mRNA degradation, depending on the degree of complementarity with target mRNA sequences (5-8). Since their discovery and first characterization, the number of human miRNAs identified and deposited in the miRBase databases (miRBase v.21, www.mirbase.org) has increaed (it is $>2,500)(9-16)$ and the research studies on miRNAs have confirmed the very high complexity of the networks constituted by miRNAs and RNA targets (17-22).

Alterations in miRNA expression have been demonstrated to be associated with different human pathologies, and guided alterations of specific miRNAs have been suggested as novel approaches for the development of innovative therapeutic protocols $(23,24)$. Studies have conclusively demonstrated that miRNAs are deeply involved in tumor onset and progression, either behaving as tumor-promoting miRNAs (oncomiRNAs and metastamiRNAs) or as tumor suppressor miRNAs $(25,26)$. In general, miRNAs able to promote cancer target mRNAs coding for tumor suppressor proteins, whereas miRNAs exhibiting tumor suppressor properties usually target mRNAs coding oncoproteins (see the scheme depicted in Fig. 1A). This has a very important implication in diagnosis and/or prognosis, including the recent discovery that the pattern of circulating cell-free miRNAs in serum allows us to perform molecular analyses on these non-invasive liquid biopsies with deep diagnostic and prognostic implications. This research field has confirmed that cancer-specific miRNAs are present in extracellular body fluids, and may play a very important role in the crosstalk between cancer cells and surrounding normal cells (27-32).

Interestingly, the evidence of the presence of miRNAs in serum, plasma and saliva supports their potential as an additional set of biomarkers for cancer. The extracellular miRNAs are protected by exosome-like structures, small intraluminal vesicles shed from a variety of cells (including cancer cells), with a biogenesis connected with endosomal sorting complex required for transport machinery in multivesicular bodies (29). For instance, miR-141 and miR-221/222 are predicted biomarkers in liquid biopsies from patients with colon cancer $(33,34)$.

On the other hand, tumor-associated miRNAs are suitable targets for intervention therapeutics, as previously reported (35-44) and summarized in Fig. 1B. The inhibition of miRNA activity can be readily achieved by the use of miRNA inhibitors and oligomers, including RNA, DNA and DNA analogues (miRNA antisense therapy) (45-47), small molecule inhibitors, locked nucleic acids (LNAs) (48-53), peptide nucleic acids (PNAs) (54-57), morpholinos (58-60), miRNA sponges (61-67), mowers (68) or through miRNA masking that inhibits miRNA function by masking the miRNA binding site of a target mRNA using a modified single-stranded RNA complementary to the target sequence (69-75). On the contrary, the enhancement of miRNA function (miRNA replacement therapy) can be achieved by the use of modified miRNA mimetics, either synthetic, or produced by plasmid or lentiviral vectors carrying miRNA sequences (76-81).
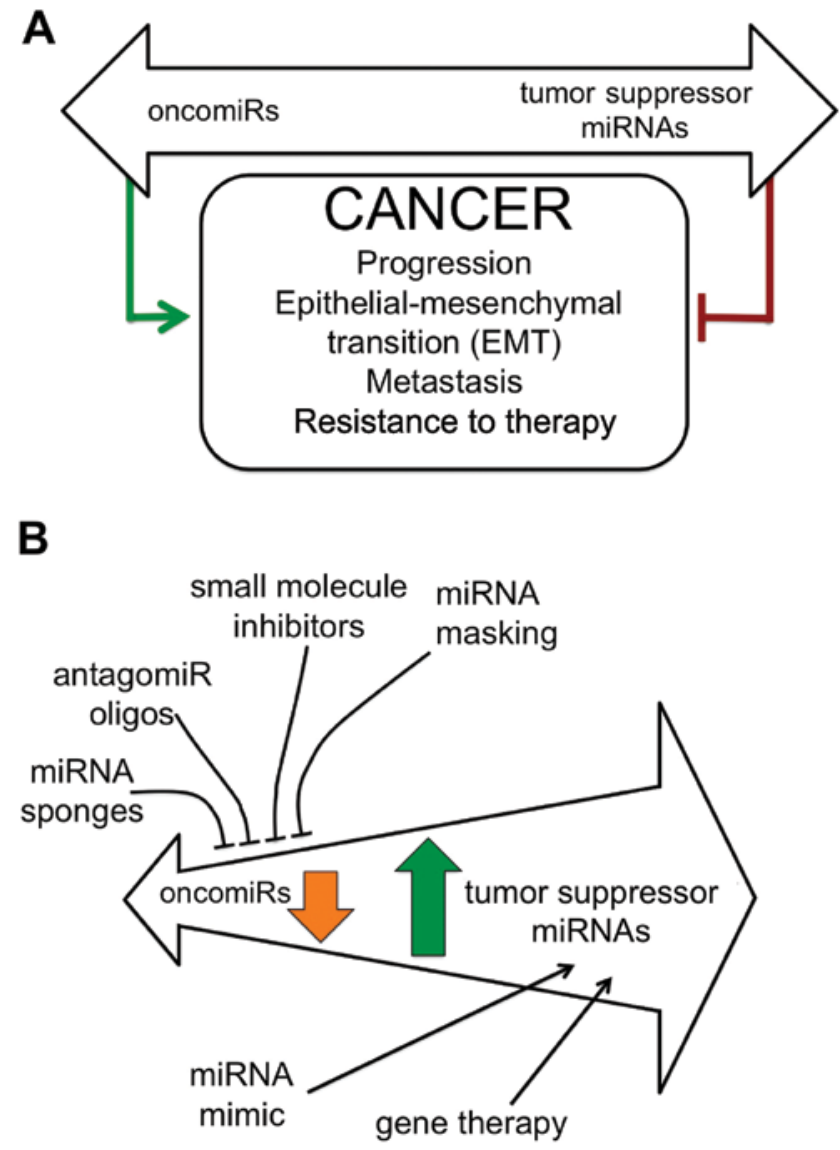

Figure 1. (A) Scheme outlining the ability of miRNAs to promote cancer and metastasis (green arrowed line) or to suppress mRNAs coding oncoproteins (red line). (B) Examples of proposed approaches for the development of therapeutic protocols to modulate the biological activity of miRNAs involved in cancer. The objectives of these molecular interventions are the downregulation of oncomiRNAs and metastamiRNAs (orange arrow) or the upregulation/mimicking of onco-suppressor miRNAs (green arrow). Modified from Ghelani et al (3).

\section{Tumor suppressor miRNAs}

Several miRNAs exhibit onco-suppressor properties by targeting mRNAs coding oncoproteins (82-105). Therefore, these onco-suppressor miRNAs have been found to be often downregulated in tumors. For instance, Fernandez et al (106) recently described the intriguing tumor suppressor activity of miR-340, showing the miR-340-mediated inhibition of multiple negative regulators of $\mathrm{p} 27$, a protein involved in apoptosis and cell cycle progression. These interactions with oncoprotein-coding mRNA targets determine the inhibition of cell cycle progression, the induction of apoptosis and growth inhibition. The miR-340-mediated downregulation of three post-transcriptional regulators [Pumilio RNA-binding family member (PUM)1, PUM2 and S-phase kinase-associated protein 2 (SKP2)] correlates with the upregulation of p27. PUM1 and PUM2 inhibit p27 at the translational level, by rendering the p27 transcript available to interact with two oncomiRs (miR-221 and miR-222), while the oncoprotein SKP2 inhibits the CDK inhibitor at the post-translational level by triggering the proteasomal degradation of $\mathrm{p} 27$, showing that miR-340 affected not only the synthesis but also the decay 
of $\mathrm{p} 27$. Moreover their data confirm the recent identification of transcripts encoding several pro-invasive proteins such as c-Met, implicated in breast cancer cell migration, RhoA and Rock1, implicated in the control of the migration and invasion of osteosarcoma cells, and E-cadherin mRNA, involved in the miR-340-induced loss of intercellular adhesion (106 and refs within).

Recently, miR-18a was demonstrated to play a protective role in colorectal carcinoma (CRC) by inhibiting the proliferation, invasion and migration of $\mathrm{CRC}$ cells by directly targeting the TBP-like 1 (TBPL1) gene. The onco-suppressor activity of miR-18a in CRC tissues and cell lines was supported by the finding that the content of this mRNA is markedly lower in tumor cells with respect to normal control tissues and cells (107). In addition Xishan et al (108) found that miR-320a acts as a novel tumor suppressor gene in chronic myelogenous leukemia (CML) and can decrease the migratory, invasive, proliferative and apoptotic behavior of CML cells, as well as epithelial-mesenchymal transition (EMT), by attenuating the expression of the BCR/ABL oncogene. Furthermore Zhao et al (109) demonstrated that miR-449a functions as a tumor suppressor in neuroblastoma by inducing cell differentiation and cell cycle arrest. Finally, Kalinowski et al (110) and $\mathrm{Gu}$ et al (111) demonstrated the significant role of miR-7 in cancer which functions by directly targeting and inhibiting key oncogenic signaling molecules involved in cell cycle progression, proliferation, invasion and metastasis. A partial list of onco-suppressor miRNAs is presented in Table I.

\section{OncomiRNAs and metastamiRNAs}

miRNAs can act as oncogenes and have been demonstrated to play a causal role in the onset and progression of human cancer (oncomiRNAs) (224-233). Recent findings have nevertheless identified a subclass of miRNAs whose expression is highly associated with the acquisition of metastatic phenotypes and are referred to as miRs endowed with either metastasis-promoting or tumor suppressor inhibitory activities $(213,234,235)$.

Recent data have revealed that miR-25 may act as an onco-miRNA in osteosarcoma, negatively regulating the protein expression of the cell cycle inhibitor, p27. In agreement with this hypothesis restoring the p27 level in miR-25-overexpressing cells was shown to reverse the enhancing effect of miR-25 on Saos-2 and U2OS cell proliferation (236). In addition a recent study published by Siu et al (237), describes miR-96 as a potential target of therapeutics for metastatic prostate cancer, demonstrating the enhanced effects in cellular growth and invasiveness of miR-96 in cell lines (AC1, AC3 and SC1) derived from prostate-specific, Pten/Tp53 double knockout mice and confirmed in tissue samples from prostate cancer patients. miR-96 acts as an oncomiR and metastamiR through TGF- $\beta /$ mTOR signaling, promoting bone metastasis and contributing to a reduced survival rate in prostate cancer (237). Furthermore Xia et al (238) demonstrated that the overexpression of miR-1908 significantly decreased the expression of PTEN in glioblastoma cells, one of the most frequently mutated tumor suppressors in human cancer, resulting in an increase in proliferation, migration and invasion. Finally Sachdeva et al (239), found that miR-182 targets multiple genes in lung metastasis and regulates intravasation, thus increasing the number of circulating tumor cells (CTCs). Only the simultaneous restoration of miR-182 target genes decreased the number of metastases in vivo, demonstrating that a single miRNA can regulate the metastasis of primary tumors in vivo by the coordinated regulation of multiple genes. Selected examples of oncomiRNAs and metastamiRNAs are presented in Tables II and III. All these miRNAs act by inhibiting tumor suppressor pathways.

\section{Mimicking tumor suppressor miRNAs in miRNA replacement therapy}

Using the development of anticancer therapies as a representative field of investigation, the therapeutic strategy based on miRNA replacement is targeted to pathological cells which downregulate onco-suppressor miRNAs playing a role in controlling the expression of mRNAs encoding key oncoproteins. The downregulation of these oncogene-targeting miRNAs is clearly the key step for oncogene upregulation leading to tumor onset and progression. Table IV presents selected examples of miRNA replacement therapy in cancer research and treatment (90-92,94-97,99).

As a first representative example, Fig. 2A presents the major results obtained by $\mathrm{Wu}$ et al (97), who reported that the in vivo restoration of miR-29b may represent an option for lung cancer treatment. To demonstrate the efficacy of this strategy, they developed a cationic lipoplexes (LPs)-based carrier that efficiently delivered miR-29b both in vitro and in vivo. LPs containing miR-29b (LP-miR-29b) efficiently delivered miR-29b to A549 cells and reduced the expression of the key target, CDK6. In a xenograft murine model, in which LPs efficiently accumulated at tumor sites, the systemic delivery of LP-miR-29b increased miR-29b expression in tumors, downregulated CDK6 mRNA expression in tumors and, as shown in the upper panels of Fig. 2A, significantly inhibited tumor growth.

A second example of miRNA replacement therapy has been published by Glover et al (304), who reported that miR-7-5p (miR-7) reduces cell proliferation in vitro and induces G1 cell cycle arrest. The systemic miR-7 administration with delivery vesicles reduced adrenocortical carcinoma (ACC) xenograft growth originating from both ACC cell lines and primary ACC cells. As far as the potential mechanisms of action, miR-7 was demonstrated to target Raf-1 proto-oncogene serine/threonine kinase (RAF1). Additionally, miR-7 therapy in vivo led to the inhibition of cyclin dependent kinase 1 (CDK1) (304). Two other methods have also been used to successfully deliver miR-7 in vivo to treat cancer. In a study by Babae et al (305), a miR-7 mimic was systemically delivered using clinically viable, biodegradable, targeted polyamide nanoparticles. This strategy led to the successful inhibition of tumor growth and vascularisation in a glioblastoma xenograft model system. In an earlier study, Wang et al (306) was able to inhibit glioma xenograft growth and metastasis using a plasmid based miR-7 vector systemically delivered by encapsulation in a cationic liposome formulation.

Moreover, Cortez et al (307) revealed a novel function of miR-200c, a member of the miR-200 family, in regulating intracellular reactive oxygen species signaling. They used a lung cancer xenograft model to demonstrate the therapeutic 
Table I. miRNAs exhibiting tumor suppressor functions.

\begin{tabular}{|c|c|c|c|c|}
\hline MicroRNA & Disease & Biological effects & $\begin{array}{l}\text { Target mRNA/ } \\
\text { pathway }\end{array}$ & Authors/(Refs.) \\
\hline miR-1 & $\begin{array}{l}\text { Head and neck } \\
\text { squamous cell } \\
\text { carcinoma (HNSCC), } \\
\text { prostate cancer }\end{array}$ & $\begin{array}{l}\text { Inhibition of cell proliferation, } \\
\text { invasion, migration and promotion } \\
\text { of apoptosis and cell cycle arrest; } \\
\text { affected cellular organization } \\
\text { of F-actin and impaired tumor cell } \\
\text { invasion and filopodia formation }\end{array}$ & $\begin{array}{l}\text { TAGLN2, FN1, } \\
\text { LASP1, XPO6, } \\
\text { TWIST1, EGFR }\end{array}$ & $\begin{array}{l}\text { Nohata et al (112); } \\
\text { Hudson et al (113); } \\
\text { Chang et al (114) }\end{array}$ \\
\hline $\operatorname{miR}-7$ & $\begin{array}{l}\text { Breast, } \\
\text { ovarian cancer }\end{array}$ & $\begin{array}{l}\text { Suppression of cell invasion and } \\
\text { metastasis; inhibition of the ability } \\
\text { of breast CSCs to metastasize to } \\
\text { the brain; inhibition of } \\
\text { tumor metastasis and reversed } \\
\text { EMT in EOC cell lines }\end{array}$ & $\begin{array}{l}\text { SETDB1, KLF4, } \\
\text { EGFR through } \\
\text { AKT/ERK1/2 } \\
\text { pathway }\end{array}$ & $\begin{array}{l}\text { Zhang et al }(115) \text {; } \\
\text { Okuda et al }(116) \text {; } \\
\text { Zhou et al }(117)\end{array}$ \\
\hline miR-let-7 & $\begin{array}{l}\text { Breast, lung, colon, } \\
\text { ovarian cancer }\end{array}$ & $\begin{array}{l}\text { Inhibition of invasion and } \\
\text { bone metastasis; reduction of } \\
\text { tumor growth, negative } \\
\text { regulation of cell } \\
\text { cycle-related oncogenes }\end{array}$ & $\begin{array}{l}\text { RAS, MYC, } \\
\text { HMGA2, Snail }\end{array}$ & $\begin{array}{l}\text { Lee and Dutta (83); } \\
\text { Sampson et al (86); } \\
\text { Trang et al (92); } \\
\text { Dangi-Garimella et al (118); } \\
\text { Takamizawa } \text { et al (119); } \\
\text { Shi et al (120); } \\
\text { Johnson } \text { et al (121) }\end{array}$ \\
\hline miR-9 & Gastric cancer & Suppression of invasion metastasis & Cyclin D1, Ets 1 & Zheng et al (122) \\
\hline $\begin{array}{l}\operatorname{miR}-15 \mathrm{a} \\
\operatorname{miR}-16-1\end{array}$ & $\begin{array}{l}\text { Chronic lymphocytic } \\
\text { leukemia (CLL), } \\
\text { multiple myeloma, } \\
\text { mantle cell lymphoma, } \\
\text { prostate cancers, } \\
\text { gastric adenocarcinoma }\end{array}$ & $\begin{array}{l}\text { Induction of apoptosis; decreased } \\
\text { tumorigenity, evading growth } \\
\text { suppressors, resisting cell death }\end{array}$ & $\begin{array}{l}\text { Bcl-2, cyclin D1, } \\
\text { WNT3A }\end{array}$ & $\begin{array}{l}\text { Aqeilan et al }(123) ; \\
\text { Calin et al }(124) ; \\
\text { Pekarsky et al }(125) \text {; } \\
\text { Bonci et al }(126) ; \\
\text { Kang et al }(127)\end{array}$ \\
\hline $\operatorname{miR}-16$ & Glioblastoma & $\begin{array}{l}\text { Repression of endothelial } \\
\text { function and angiogenesis }\end{array}$ & Bmi-1 & Chen et al (128) \\
\hline miR-18a & Colorectal cancer & $\begin{array}{l}\text { Decrease of cell migration, altered cell } \\
\text { morphology, G1/S phase cell cycle } \\
\text { arrest, increased apoptosis }\end{array}$ & $\mathrm{CDC} 42$ & Humphreys et al (129) \\
\hline $\operatorname{miR}-25$ & Prostate cancer & Inhibition of extravasion in vivo & $\alpha v, \alpha 6$ integrins & Zoni et al (130) \\
\hline miR-27a & Acute leukemia & $\begin{array}{l}\text { Inhibition of cell growth due at least } \\
\text { in part, to increased cellular apoptosis }\end{array}$ & Bax and Bad & Scheibner et al (94) \\
\hline $\operatorname{miR}-29 c$ & $\begin{array}{l}\text { Nasopharyngeal } \\
\text { carcinoma }\end{array}$ & Inhibition of invasion and metastasis & $\begin{array}{l}\text { Collagens, } \\
\text { Laminin } \gamma 1\end{array}$ & Sengupta et al (131) \\
\hline $\begin{array}{l}\text { miR-29s } \\
(\mathrm{miR}-29 \mathrm{a}, \\
\text { miR-29b1, } \\
\text { miR-29b2, } \\
\text { miR-29c) }\end{array}$ & $\begin{array}{l}\text { Lung cancer, cervical } \\
\text { carcinogenesis, } \\
\text { cholangiocarcinoma, } \\
\text { hepatocellular } \\
\text { carcinoma (HCC), } \\
\text { mantle cell lymphoma } \\
\text { (MCL), melanoma and } \\
\text { acute myeloid leukemia } \\
\text { (AML) B and T cells }\end{array}$ & $\begin{array}{l}\text { Decrease in cell proliferation and } \\
\text { an increase in cell senescence and } \\
\text { apoptosis; decreased AML cell growth } \\
\text { and impairement of colony formation, } \\
\text { longer survival of treated mice; } \\
\text { improvement of anti-leukemic } \\
\text { activity of decitabine }\end{array}$ & $\begin{array}{l}\text { CDK6, Ppm1d, } \\
\text { osteonectin, Mcl-1, } \\
\text { KIT, SP1, Bcl-2, } \\
\text { DNMT3A, DNMT3B, } \\
\text { DNMTs, Tcl-1, } \\
\text { extracellular matrix } \\
\text { genes, FLT3, } \\
\text { Cdc42, p85a }\end{array}$ & $\begin{array}{l}\text { Ugalde et al }(132) ; \\
\text { Garzon } \text { et al }(133) ; \\
\text { Garzon et al }(134) ; \\
\text { Huang et al }(98) ; \\
\text { Kapinas et al }(135) ; \\
\text { Mott et al }(136) ; \\
\text { Fabbri et al }(137) ; \\
\text { Xiong et al }(138) ; \\
\text { Filkowski et al }(139) ; \\
\text { Wang et al }(140) ; \\
\text { Hu et al }(141)\end{array}$ \\
\hline miR-30b & Laryngeal carcinoma & $\begin{array}{l}\text { Antitumor and pro-apoptotic } \\
\text { effect in vivo and in vitro }\end{array}$ & p53 via MDM2 & Li and Wang (142) \\
\hline $\operatorname{miR}-31$ & $\begin{array}{l}\text { Breast cancer, lung } \\
\text { adenocarcinoma } \\
\text { (stem cells) }\end{array}$ & $\begin{array}{l}\text { Inhibition of multiple steps of } \\
\text { metastasis, including invasion, } \\
\text { anoikis and colonization }\end{array}$ & $\begin{array}{l}\text { MET-PI3K-Akt, } \\
\text { WAVE3 }\end{array}$ & $\begin{array}{l}\text { Hou et al (143); } \\
\text { Valastyan et al (144); } \\
\text { Sossey-Alaoui et al (145) }\end{array}$ \\
\hline
\end{tabular}


Table I. Continued.

\begin{tabular}{|c|c|c|c|c|}
\hline MicroRNA & Disease & Biological effects & $\begin{array}{l}\text { Target mRNA/ } \\
\text { pathway }\end{array}$ & Authors/(Refs.) \\
\hline miR-33a & $\begin{array}{l}\text { Chronic myelogenous } \\
\text { leukemia }(\mathrm{CML}) \\
\text { colon carcinoma }\end{array}$ & $\begin{array}{l}\text { Decelerated cell proliferation; } \\
\text { reduced tumor cell proliferation }\end{array}$ & Pim-1 & $\begin{array}{l}\text { Thomas et al (95); } \\
\text { Ibrahim et al (91) }\end{array}$ \\
\hline $\operatorname{miR}-33 b$ & $\begin{array}{l}\text { Breast cancer lung } \\
\text { metastasis, osteosarcoma }\end{array}$ & $\begin{array}{l}\text { Inhibition of stemness, migration, } \\
\text { invasion and metastasis }\end{array}$ & $\begin{array}{l}\text { HMGA2, SALL4, } \\
\text { Twist1, c-MYC }\end{array}$ & $\begin{array}{l}\text { Lin et al }(146) \\
\text { Xu et al }(147)\end{array}$ \\
\hline miR-34a & $\begin{array}{l}\text { Breast, lung, colon, } \\
\text { kidney, prostate, } \\
\text { bladder, pancreatic, } \\
\text { bone and lung cancer, } \\
\text { and melanoma }\end{array}$ & $\begin{array}{l}\text { Blocking of tumor growth; } \\
\text { inhibition of cell migration, } \\
\text { invasion and metastasis of cancer } \\
\text { cells; suppression of prostate CSCs } \\
\text { and metastasis; decrease in } \\
\text { the production of the chemokine } \\
\text { CCL22; disturbance of the bone } \\
\text { metastatic niche }\end{array}$ & $\begin{array}{l}\text { Bcl-2, cyclin D1, } \\
\text { cyclin E2, CDK4, } \\
\text { CDK6, c-MYC, MET, } \\
\text { N-MYC, SIRT1, } \\
\text { Fra-1, CD44, } \\
\text { CCL44, Tgif2 }\end{array}$ & $\begin{array}{l}\text { He et al (148); } \\
\text { Bommer et al }(149) ; \\
\text { Fujita et al }(150) ; \\
\text { Leucci et al }(151) ; \\
\text { Saito et al }(152) ; \\
\text { Wei et al }(153) ; \\
\text { Yamakuchi et al (154); } \\
\text { Lodygin et al (155); } \\
\text { Wiggins et al }(90) ; \\
\text { Yang et al }(156) ; \\
\text { Yang et al }(157) ; \\
\text { Liu et al (158); } \\
\text { Krzeszinski et al (159) }\end{array}$ \\
\hline miR-34b & $\begin{array}{l}\text { Breast, ovarian, } \\
\text { endometrial cancer }\end{array}$ & $\begin{array}{l}\text { Tumor suppressor in } \\
\text { estrogen-dependent } \\
\text { cell growth }\end{array}$ & $\begin{array}{l}\text { Cyclin D1 and JAG1 } \\
\text { in } \mathrm{ER}^{+} / \text {wild-type } \\
\text { p53 }\end{array}$ & $\begin{array}{l}\text { Lee } \text { et al }(102) \\
\text { Wang } \text { et al }(160)\end{array}$ \\
\hline $\operatorname{miR}-34 c$ & $\begin{array}{l}\text { Breast, ovarian cancer, } \\
\text { lung metastasis }\end{array}$ & $\begin{array}{l}\text { Inhibition of cell migration; } \\
\text { invasion and lung metastasis }\end{array}$ & Fra-1 & $\begin{array}{l}\text { Yang et al }(156) \\
\text { Yu et al }(161)\end{array}$ \\
\hline miR-101-3p & $\begin{array}{l}\text { Salivary gland } \\
\text { adenoid cystic } \\
\text { carcinoma }\end{array}$ & $\begin{array}{l}\text { Suppression of cell proliferation, } \\
\text { invasion and enhanced } \\
\text { chemotherapeutic sensitivity }\end{array}$ & Pim-1 & Liu et al (162) \\
\hline $\operatorname{miR}-122 \mathrm{a}$ & $\begin{array}{l}\text { Liver tumor } \\
\text { and disease }\end{array}$ & $\begin{array}{l}\text { Reduced disease manifestation } \\
\text { and tumor incidence }\end{array}$ & Klf6 & Tsai et al (163) \\
\hline miR-124 & $\begin{array}{l}\text { Intrahepatic, bladder, } \\
\text { colorectal and lung } \\
\text { cancer, osteosarcoma, } \\
\text { neuroblastoma, glioma }\end{array}$ & $\begin{array}{l}\text { Modulation of the intercellular } \\
\text { adhesion of leading cells; inhibition } \\
\text { of EMT in vitro and suppression of } \\
\text { intrahepatic and pulmonary } \\
\text { metastasis in vivo; suppression of } \\
\text { motility and angiogenesis in bladder } \\
\text { cancer cells, of migration and } \\
\text { invasion of U-2OS and Saos-2 cells }\end{array}$ & $\begin{array}{l}\text { Integrin } \beta 1, \text { ROCK2, } \\
\text { EZH2, UHRF1, } \\
\text { ROR2, MYO10, } \\
\text { DNMT3B, } \\
\text { PTB/PKM1/ } \\
\text { PKM2 cascade }\end{array}$ & $\begin{array}{l}\text { Taniguchi et al }(164) ; \\
\text { Huang et al }(165) ; \\
\text { Kato et al }(166) ; \\
\text { Zheng et al }(167) ; \\
\text { Wang et al }(168) ; \\
\text { Zhang et al }(169) ; \\
\text { Sun et al }(170) ; \\
\text { Sun et al }(171) ; \\
\text { Chen et al }(172) ; \\
\text { Zhang et al }(173)\end{array}$ \\
\hline $\operatorname{miR}-125 \mathrm{a}$ & Cervical cancer & $\begin{array}{l}\text { Suppression of tumor growth, } \\
\text { invasion, metastasis }\end{array}$ & ARID3B, STAT3 & $\begin{array}{l}\text { Cowden Dahl et al (174); } \\
\text { Fan et al (175) }\end{array}$ \\
\hline miR-126 & $\begin{array}{l}\text { Non-small cell lung } \\
\text { cancer cells, breast, } \\
\text { thyroid, liver, } \\
\text { colorectal cancer, } \\
\text { osteosarcoma }\end{array}$ & $\begin{array}{l}\text { Tumor suppressor genes } \\
\text { involved in the control of } \\
\text { cell proliferation and cell death, } \\
\text { cell migration and blood vessel } \\
\text { formation; inhibition of cell } \\
\text { proliferation, invasion, migration } \\
\text { and tumorigenesis; suppression of } \\
\text { tumor metastasis and angiogenesis } \\
\text { in hepatocellular carcinoma }\end{array}$ & $\begin{array}{l}\text { EGFL 7, SLC7A5, } \\
\text { ADAM9, IGFBP2, } \\
\text { PITPNC1, MERTK, } \\
\text { SDF-1 } \alpha\end{array}$ & $\begin{array}{l}\text { Sun } \text { et al }(176) ; \\
\text { Xiong et al }(177) \text {; } \\
\text { Wang et al }(178) \text {; } \\
\text { Wen } \text { et al }(179) ; \\
\text { Jiang et al }(180) \text {; } \\
\text { Du et al }(181) ; \\
\text { Zhang } \text { et al }(182) \text {; } \\
\text { Png et al }(183)\end{array}$ \\
\hline miR-128 & $\begin{array}{l}\text { Glioblastoma, } \\
\text { hepatocellular } \\
\text { carcinoma, acute } \\
\text { lymphoblastic } \\
\text { leukemia }\end{array}$ & $\begin{array}{l}\text { Inhibition of angiogenesis and } \\
\text { proliferation, inhibition of } \\
\text { tumor cell progression }\end{array}$ & $\begin{array}{l}\text { WEE1, p70S6K1, } \\
\text { Msi1, E2F3a, } \\
\text { Bmi-1, EGFR, } \\
\text { PDGFRA, PIK3R1 }\end{array}$ & $\begin{array}{l}\text { Shi et al (184); } \\
\text { Wuchty et al (185); } \\
\text { Zhang et al (186); } \\
\text { Huang et al (187) }\end{array}$ \\
\hline
\end{tabular}


Table I. Continued.

\begin{tabular}{|c|c|c|c|c|}
\hline MicroRNA & Disease & Biological effects & $\begin{array}{l}\text { Target mRNA/ } \\
\text { pathway }\end{array}$ & Authors/(Refs.) \\
\hline $\begin{array}{l}\operatorname{miR}-133 a \\
\text { miR-133b }\end{array}$ & $\begin{array}{l}\text { Esophageal } \\
\text { squamous cell } \\
\text { carcinoma }\end{array}$ & $\begin{array}{l}\text { Inhibition of cell proliferation } \\
\text { and cell invasion }\end{array}$ & FSCN1 & Kano et al (188) \\
\hline $\operatorname{miR}-135 \mathrm{a}$ & Prostate cancer & $\begin{array}{l}\text { Inhibition of cell invasion } \\
\text { and migration }\end{array}$ & ROCK1, ROCK2 & Kroiss et al (189) \\
\hline miR-137 & Colorectal cancer & Reduction of invasiveness & FMNL2 & Liang et al (190) \\
\hline miR-143 & $\begin{array}{l}\text { Non-small } \\
\text { cell lung cancer }\end{array}$ & $\begin{array}{l}\text { Suppression of cell proliferation; } \\
\text { inhibition of cell migration and } \\
\text { invasion; induction of apoptosis }\end{array}$ & Limk1 & Xia et al (191) \\
\hline miR-145 & $\begin{array}{l}\text { Esophageal squamous } \\
\text { cell carcinoma, } \\
\text { colon carcinoma, } \\
\text { gastric cancer, } \\
\text { neuroblastoma }\end{array}$ & $\begin{array}{l}\text { Inhibition of cell proliferation and } \\
\text { cell invasion; reduced tumor } \\
\text { proliferation and increased apoptosis; } \\
\text { attenuation of gastric cancer cell } \\
\text { migratory and invasive abilities in vitro } \\
\text { and suppression of the metastatic } \\
\text { cascade in vivo; inhibition of } \\
\text { the invasion and metastasis } \\
\text { of neuroblastoma cells }\end{array}$ & $\begin{array}{l}\text { FSCN1, c-MYC, } \\
\text { ERK5, N-cadherin, } \\
\text { HIF- } 2 \alpha\end{array}$ & $\begin{array}{l}\text { Kano et al }(188) ; \\
\text { Ibrahim } \text { et al }(91) ; \\
\text { Gao et al }(192) ; \\
\text { Zhang et al }(193)\end{array}$ \\
\hline $\mathrm{miR}-146 \mathrm{a} / \mathrm{b}$ & $\begin{array}{l}\text { Prostate, } \\
\text { breast cancer }\end{array}$ & $\begin{array}{l}\text { Inhibition of cell invasion } \\
\text { and migration }\end{array}$ & $\begin{array}{l}\text { IRAK1, TRAF6, } \\
\text { ROCK1 }\end{array}$ & $\begin{array}{l}\text { Bhaumik et al (194); } \\
\text { Lin et al (195) }\end{array}$ \\
\hline $\operatorname{miR}-148 \mathrm{a}$ & $\begin{array}{l}\text { Liver, lung } \\
\text { cancer }\end{array}$ & $\begin{array}{l}\text { Inhibition of hepatoma cell } \\
\text { migration in vitro and pulmonary } \\
\text { metastatic colonization in vivo }\end{array}$ & $\begin{array}{l}\text { MET/Snail } \\
\text { signaling }\end{array}$ & Zhang et al (196) \\
\hline $\operatorname{miR}-148 b$ & Breast cancer & $\begin{array}{l}\text { Inhibition of multiple steps of } \\
\text { tumor progression via the regulation } \\
\text { of invasion, resistance to anoikis, } \\
\text { extravasation, lung metastasis, } \\
\text { colonization and chemo- } \\
\text { therapeutic response }\end{array}$ & $\begin{array}{l}\text { ITGA5, ROCK1, } \\
\text { PIK3CA/p110 } \alpha \\
\text { NRAS, CSF1 }\end{array}$ & Cimino et al (197) \\
\hline miR-149 & Breast, lung cancer & $\begin{array}{l}\text { Inhibition of basal-like breast } \\
\text { cancer cell migration and invasion } \\
\text { in vitro; impairment of } \\
\text { lung colonization in vivo }\end{array}$ & Rap1a, Rap1b & Bischoff et al (198) \\
\hline $\operatorname{miR}-181 b$ & $\begin{array}{l}\text { Chronic lymphocytic } \\
\text { leukemia }\end{array}$ & Inhibition of disease progression & Mcl-1, Bcl-2 & Visone et al (199) \\
\hline miR-182 & Glioblastoma & $\begin{array}{l}\text { Inhibition of cell growth } \\
\text { and cell differentiation }\end{array}$ & $\begin{array}{l}\text { Bcl-2L12, } \\
\text { c-MET, HIF2A }\end{array}$ & Kouri et al (200) \\
\hline $\operatorname{miR}-193 b$ & $\begin{array}{l}\text { Breast cancer, } \\
\text { pancreatic ductal } \\
\text { adenocarcinoma }\end{array}$ & $\begin{array}{l}\text { Alteration of ER } \alpha \text { signaling, such as } \\
\text { steroid synthesis and downregulation } \\
\text { of the ER } \alpha \text { receptor; negative regulation } \\
\text { of long non-coding oncogenic RNA }\end{array}$ & $\begin{array}{l}\text { AKR1C2, AKR1C1, } \\
\text { YWHAZ (14-3-3 } \\
\text { family protein), } \\
\text { RNA MIR31HG }\end{array}$ & $\begin{array}{l}\text { Leivonen et al (201); } \\
\text { Yang et al (202) }\end{array}$ \\
\hline miR-198 & $\begin{array}{l}\text { Hepatocellular } \\
\text { carcinoma }\end{array}$ & $\begin{array}{l}\text { Inhibition of migration } \\
\text { and invasion }\end{array}$ & HGF/c-MET & Tan et al (203) \\
\hline miR-204 & $\begin{array}{l}\text { Neuroblastoma, } \\
\text { glioma }\end{array}$ & $\begin{array}{l}\text { Stimulation of increased } \\
\text { sensitivity to cisplatin treatment } \\
\text { and promotion of cell survival; } \\
\text { alteration of glioma progression, } \\
\text { invasion and migration }\end{array}$ & TrkB & $\begin{array}{l}\text { Bao et al (204); } \\
\text { Xia et al (205) }\end{array}$ \\
\hline miR-205 & $\begin{array}{l}\text { Human prostate } \\
\text { cancer }\end{array}$ & $\begin{array}{l}\text { Reduction of cell migration/ } \\
\text { invasion through downregulation } \\
\text { of protein kinase } \mathrm{C} \text { epsilon }\end{array}$ & $\begin{array}{l}\text { CHN1, ErbB3, } \\
\text { E2F1, E2F5, } \\
\text { ZEB2, PRKCE }\end{array}$ & Gandellini et al (206) \\
\hline
\end{tabular}


Table I. Continued.

\begin{tabular}{|c|c|c|c|c|}
\hline MicroRNA & Disease & Biological effects & $\begin{array}{l}\text { Target mRNA/ } \\
\text { pathway }\end{array}$ & Authors/(Refs.) \\
\hline miR-206 & Breast cancer & $\begin{array}{l}\text { Inhibition of cell invasion } \\
\text { and migration }\end{array}$ & MET & Chen et al (207) \\
\hline miR-214 & $\begin{array}{l}\text { Colorectal cancer, } \\
\text { liver metastasis }\end{array}$ & $\begin{array}{l}\text { Suppression of cell migration } \\
\text { and invasion in vitro; inhibition } \\
\text { of liver metastasis of colorectal } \\
\text { cancer cells in vivo }\end{array}$ & FGFR1 & Chen et al (208) \\
\hline $\operatorname{miR}-218$ & Gastric cancer & Suppression of tumor metastases & ROBO1 & Tie et al (209) \\
\hline $\operatorname{miR}-296-5 p$ & Prostate cancer & $\begin{array}{l}\text { Reduction of growth invasion } \\
\text { and progression }\end{array}$ & HMGA1 & Wei et al (210) \\
\hline miR-302 & Breast cancer & $\begin{array}{l}\text { Sensitization of radioresistant breast } \\
\text { cancer cells to ionizing radiation }\end{array}$ & AKT1, RAD52 & Liang et al (99) \\
\hline $\operatorname{miR}-302 b$ & $\begin{array}{l}\text { Hepatocellular } \\
\text { carcinoma }\end{array}$ & Suppression of cell proliferation & EGFR & Wang et al (211) \\
\hline miR-335 & Breast cancer & $\begin{array}{l}\text { Inhibition of cell invasion, } \\
\text { migration and metastasis }\end{array}$ & $\begin{array}{l}\text { SOX } 4, \text { PTPRN2, } \\
\text { MERTK, TNC }\end{array}$ & $\begin{array}{l}\text { Tavazoie et al (212); } \\
\text { Hurst et al (213) }\end{array}$ \\
\hline $\operatorname{miR}-383$ & Medulloblastoma & Control of cell growth & PRDX3 & Li et al (214) \\
\hline $\operatorname{miR}-449$ & $\begin{array}{l}\text { Gastric cancer, non- } \\
\text { small cell lung cancer }\end{array}$ & $\begin{array}{l}\text { Inhibition of cell proliferation, } \\
\text { inhibition of migration and invasion }\end{array}$ & $\begin{array}{l}\text { GMNN, MET, } \\
\text { CCNE2, SIRT1 }\end{array}$ & $\begin{array}{l}\text { Bou Kheir et al (215) } \\
\text { Luo et al (216) }\end{array}$ \\
\hline $\operatorname{miR}-493$ & Colon, lung cancer & $\begin{array}{l}\text { Inhibition of the settlement of } \\
\text { metastasized colon cancer cells } \\
\text { in the liver; promotion of the death } \\
\text { of colon cancer cells; suppression } \\
\text { of tumor growth, invasion and } \\
\text { metastasis in lungs }\end{array}$ & $\begin{array}{l}\text { IGFR, E2F1, } \\
\text { MKK } 7\end{array}$ & $\begin{array}{l}\text { Okamoto et al (217); } \\
\text { Gu et al (218); } \\
\text { Sakai et al (219) }\end{array}$ \\
\hline $\operatorname{miR}-504$ & $\begin{array}{l}\text { Hypopharyngeal } \\
\text { squamous cell } \\
\text { carcinoma }\end{array}$ & $\begin{array}{l}\text { Inhibition of cancer cells } \\
\text { proliferation }\end{array}$ & CDK6 & Kikkawa et al (220) \\
\hline $\begin{array}{l}\mathrm{miR}- \\
520 \mathrm{c} / 373\end{array}$ & Breast cancer & $\begin{array}{l}\text { Inhibition of cell invasion in vitro } \\
\text { and the cell intravasation in vivo }\end{array}$ & $\begin{array}{l}\text { RELA, } \\
\text { TGFBR2 }\end{array}$ & Keklikoglou et al (221) \\
\hline $\operatorname{miR}-545$ & $\begin{array}{l}\text { Pancreatic ductal } \\
\text { adenocarcinoma, } \\
\text { lung cancer cells }\end{array}$ & $\begin{array}{l}\text { Inhibition of cell growth } \\
\text { and proliferation }\end{array}$ & RIG-1, CDK4 & $\begin{array}{l}\text { Song et al (222); } \\
\text { Bowen et al (223) }\end{array}$ \\
\hline miR-596 & $\begin{array}{l}\text { Oral squamous cell } \\
\text { carcinoma (OSCC) }\end{array}$ & Growth inhibition & LGALS3BP & Endo et al (96) \\
\hline
\end{tabular}

potential of the systemic delivery of miR-200c to enhance radiosensitivity in lung cancer. The results obtained suggest that the antitumor effects of miR-200c result partially from its regulation of the oxidative stress response; they further suggested that miR-200c, in combination with radiation, may represent an effective therapeutic strategy in the future.

Recently, Wu et al (308) reported that the expression of miR-708-5p suppressed lung cancer invasion and metastasis in vitro and in vivo. In particular, it induces apoptosis and suppresses cell migration by inhibiting the cytoplasmic localization of p21, and also weakens the stem cell-like properties of lung cancer cells. In their study, they present the systemic delivery of the PEI/miR-708-5p complexes for miRNA replacement therapy in a mouse model of lung cancer, demonstrating an efficient antitumor activity with no side-effects.

\section{Targeting oncomiRNAs}

The effects of therapeutic molecules against miRNAs have been the object of very recent studies, in part summarized in Table V (309-316). Of course, the endpoint of the treatment of target cells with molecules against selected miRNAs is the alteration of miRNA-regulated genes. As a first example, Wagenaar et al (317) developed potent and specific singlestranded oligonucleotide inhibitors of miR-21 and used them to verify dependency on miR-21 in a panel of liver cancer cell lines. Treatment with anti-miR-21, but not with a mismatch control anti-miRNA, resulted in the significant derepression of direct targets of miR-21 and led to the loss of viability in the majority of HCC cell lines tested. The robust induction of caspase activity, apoptosis and necrosis was noted in the 
Table II. miRNAs exhibiting oncogenic functions.

\begin{tabular}{|c|c|c|c|c|}
\hline MicroRNA & Disease & Biological effects & $\begin{array}{l}\text { Target mRNA/ } \\
\text { pathway }\end{array}$ & Authors/(Refs.) \\
\hline miR-10b & $\begin{array}{l}\text { Human esophageal } \\
\text { cancer cells, } \\
\text { gastric carcinoma }\end{array}$ & $\begin{array}{l}\text { Promotion of migration } \\
\text { and invasion }\end{array}$ & KLF4 & $\begin{array}{l}\text { Tian et al (240); } \\
\text { Wang et al }(241)\end{array}$ \\
\hline $\operatorname{miR}-21$ & $\begin{array}{l}\text { Breast, colon, pancreatic, } \\
\text { lung, prostate, liver } \\
\text { and stomach cancer, } \\
\text { chronic lymphocytic } \\
\text { leukemia; acute myeloid } \\
\text { leukaemia, glioblastoma, } \\
\text { neuroblastoma }\end{array}$ & $\begin{array}{l}\text { Stimulation of cellular } \\
\text { proliferation; action on } \\
\text { mitochondrial apoptosis } \\
\text { tumor-supressive pathways, } \\
\text { resisting cell death }\end{array}$ & $\begin{array}{l}\text { PTEN, TPM1, } \\
\text { PDCD } 4, \text { p63, } \\
\text { RECK, p53, } \\
\text { TGF- } \beta\end{array}$ & $\begin{array}{l}\text { Chan et al (242); } \\
\text { Zhu et al (230); } \\
\text { Frankel et al (231); } \\
\text { Volinia et al (233) }\end{array}$ \\
\hline $\operatorname{miR}-23 b$ & Renal cancer cells & $\begin{array}{l}\text { Downregulation of POX } \\
\text { (tumor suppressor), } \\
\text { increase in HIF signaling }\end{array}$ & POX & Liu et al (243) \\
\hline $\operatorname{miR}-27 \mathrm{a}$ & Prostate cancer & $\begin{array}{l}\text { Increase in the expression of } \\
\text { AR target genes and prostate } \\
\text { cancer cell growth }\end{array}$ & PHB & Fletcher et al (244) \\
\hline miR-100 & $\begin{array}{l}\text { Myeloid leukemia, } \\
\text { glioma }\end{array}$ & $\begin{array}{l}\text { Promotion of cell differentiation, } \\
\text { survival and apoptosis }\end{array}$ & RBSP3, ATM & $\begin{array}{l}\mathrm{Ng} \text { et al }(245) ; \\
\text { Zheng et al }(246)\end{array}$ \\
\hline $\operatorname{miR}-125 b$ & B-cell leukemia & $\begin{array}{l}\text { Induction of cell differentiation } \\
\text { and transformation }\end{array}$ & $\begin{array}{l}\text { MAP3K11, } \\
\text { ARID3B }\end{array}$ & Knackmuss et al (247) \\
\hline $\begin{array}{l}\operatorname{miR}-132 \\
\operatorname{miR}-212\end{array}$ & $\begin{array}{l}\text { Pancreatic } \\
\text { adenocarcinoma (PDAC) }\end{array}$ & $\begin{array}{l}\text { Stimulation of cell proliferation } \\
\text { via the } \beta 2 \text { adrenergic pathway }\end{array}$ & $\mathrm{Rb} 1$ & Park et al 2011 (248) \\
\hline miR-155 & $\begin{array}{l}\text { Lymphoma, leukemia, } \\
\text { breast, colon, } \\
\text { lung, pancreatic, } \\
\text { thyroid brain cancer, } \\
\text { diffuse large B-cell } \\
\text { lymphoma (DLBCL) }\end{array}$ & $\begin{array}{l}\text { Causes the constitutive activation } \\
\text { of signal transducer and activator } \\
\text { of transcription } 3 \text {, sustaining } \\
\text { proliferative signaling, } \\
\text { resistance of cell death, activation } \\
\text { invasion, migration and metastasis }\end{array}$ & $\begin{array}{l}\text { SOCS1, RhoA, } \\
\text { FOXO3a, } \\
\text { VHL }\end{array}$ & $\begin{array}{l}\text { Kong et al (249); } \\
\text { Jiang et al (250); } \\
\text { Czyzyk-Krzeska et al (251); } \\
\text { Wang et al (252); } \\
\text { Ling et al (253); } \\
\text { Musilova et al (254) }\end{array}$ \\
\hline $\operatorname{miR}-17$ & Neuroblastoma & $\begin{array}{l}\text { Marked increase of in vitro } \\
\text { and in vivo tumorigenesis }\end{array}$ & $\mathrm{p} 21, \mathrm{BIM}$ & Fontana et al (255) \\
\hline $\operatorname{miR}-182$ & Melanoma & Promotion of melanoma metastases & MITF, FOXO3 & Segura et al (256) \\
\hline $\operatorname{miR}-214$ & Ovarian cancer & $\begin{array}{l}\text { Stimulation of cell survival } \\
\text { and cisplatin resistance }\end{array}$ & PTEN & Yang et al (257) \\
\hline $\begin{array}{l}\operatorname{miR}-221 \\
\operatorname{miR}-222\end{array}$ & $\begin{array}{l}\text { Atypical teratoid/rhabdoid } \\
\text { tumors (ATRT), } \\
\text { osteosarcoma, glioma, } \\
\text { breast cancer, follicular } \\
\text { thyroid carcinoma (FTC), } \\
\text { digestive system } \\
\text { carcinoma }\end{array}$ & $\begin{array}{l}\text { Decrease of cell cycle inhibitor } \\
\text { p } 27^{\text {Kip1 }} \text {, tumor development and } \\
\text { progression by regulating proliferative } \\
\text { signaling pathways, altering } \\
\text { telomere and telomerase } \\
\text { activity, avoiding cell death from } \\
\text { tumor suppressors, autophagy } \\
\text { and apoptosis, monitoring } \\
\text { angiogenesis, supporting } \\
\text { epithelial-mesenchymal transition, } \\
\text { and even controlling cell-specific } \\
\text { function within the microenvironment }\end{array}$ & $\begin{array}{l}\text { p27 }{ }^{\text {Kip1 }}, \text { PTEN, } \\
\text { KIT, TRPS1, } \\
\text { PUMA, PTP } \mu, \\
\text { FOXO3, PIK3R1, } \\
\text { TIMP3, TIMP2, } \\
\text { DDIT4, MDM2, } \\
\text { ER } \alpha, \text { SOCS3, } \\
\text { OCS1, HDAC6, } \\
\text { ANGPTL2, BBC3, } \\
\text { BMF, RECK, } \\
\text { PDLIM2, RelA, } \\
\text { p57 }\end{array}$ & $\begin{array}{l}\text { Zhang et al (258); } \\
\text { Garofalo } \text { et al (259); } \\
\text { Quintavalle } \text { et al (260); } \\
\text { Chen } \text { et al (261); } \\
\text { Matsuzaki et al (262) }\end{array}$ \\
\hline miR-296 & Brain tumors & Promotion of angiogenesis & HGS & Wurdinger et al (263) \\
\hline miR-301 & Breast cancer & $\begin{array}{l}\text { Promotion of growth, proliferation, } \\
\text { invasion and metastases }\end{array}$ & $\begin{array}{l}\text { FOXF2, BBC3, } \\
\text { PTEN }\end{array}$ & Shi et al (264) \\
\hline $\begin{array}{l}\operatorname{miR}-372 \\
\operatorname{miR}-373\end{array}$ & Testicular tumors & $\begin{array}{l}\text { Promotion of tumorigenesis } \\
\text { in cooperation with RAS }\end{array}$ & LATS2 & Voorhoeve et al (265) \\
\hline $\operatorname{miR}-375$ & Gastric cancer & Promotion of carcinogenesis & JAK2, PDK1 & Xu et al (266) \\
\hline
\end{tabular}


Table II. Continued.

\begin{tabular}{|c|c|c|c|c|}
\hline MicroRNA & Disease & Biological effects & $\begin{array}{l}\text { Target mRNA/ } \\
\text { pathway }\end{array}$ & Authors/(Refs.) \\
\hline miR-378 & Breast carcinoma & $\begin{array}{l}\text { Ehnancement of cell survival; } \\
\text { reduction of caspase- } 3 \text { activity; } \\
\text { promotion of growth } \\
\text { and angiogenesis }\end{array}$ & Sufu, Fus-1 & Lee et al (267) \\
\hline $\operatorname{miR}-519 a$ & $\begin{array}{l}\text { Hepatocellular carcinoma, } \\
\text { breast cancer }\end{array}$ & $\begin{array}{l}\text { Promotion of tumor growth, } \\
\text { proliferation; inhibition } \\
\text { of apoptosis; tamoxifen } \\
\text { resistance }\end{array}$ & $\begin{array}{l}\text { PTEN/PI3K/ } \\
\text { AKT/FOXF2 }\end{array}$ & $\begin{array}{l}\text { Tu et al (268); } \\
\text { Shao et al (269); } \\
\text { Ward et al (270) }\end{array}$ \\
\hline miR-675 & Colorectal cancer & $\begin{array}{l}\text { Overexpression of H19 } \\
\text { (oncofetal non-coding RNA) } \\
\text { in cancer tissues }\end{array}$ & $\mathrm{RB}$ & Tsang et al (271) \\
\hline $\operatorname{miR}-1908$ & Glioblastoma & $\begin{array}{l}\text { Promotion of anchorage independent } \\
\text { growth in vitro, increasing } \\
\text { of tumor forming potential in vivo }\end{array}$ & PTEN & Xia et al (238) \\
\hline
\end{tabular}

\section{A}

miRNA replacement therapy

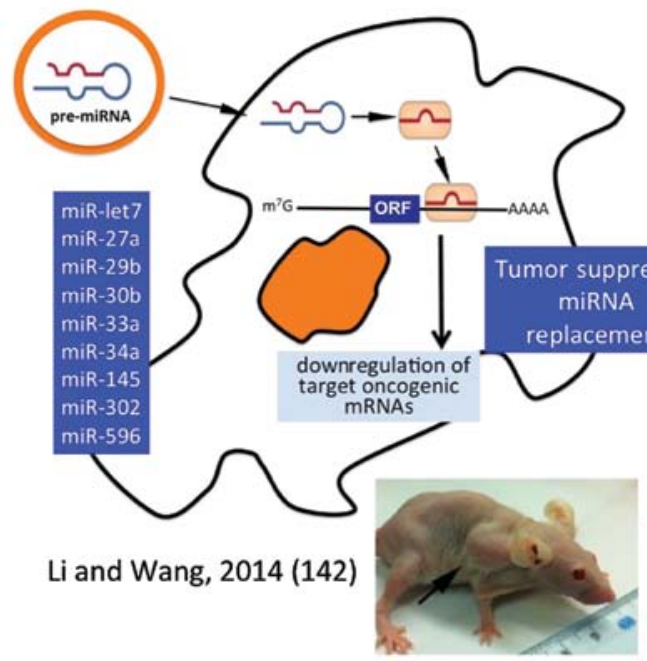

Vehicle
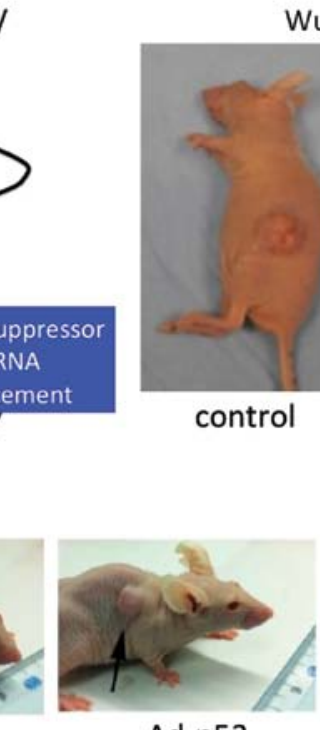

Ad-p53

Wu et al, 2013 (97)

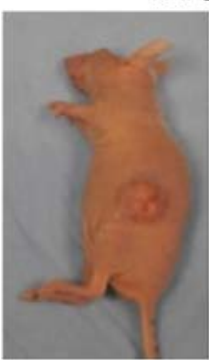

control

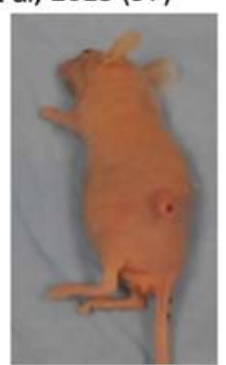

lipoplexes

miR-29b

\section{B}

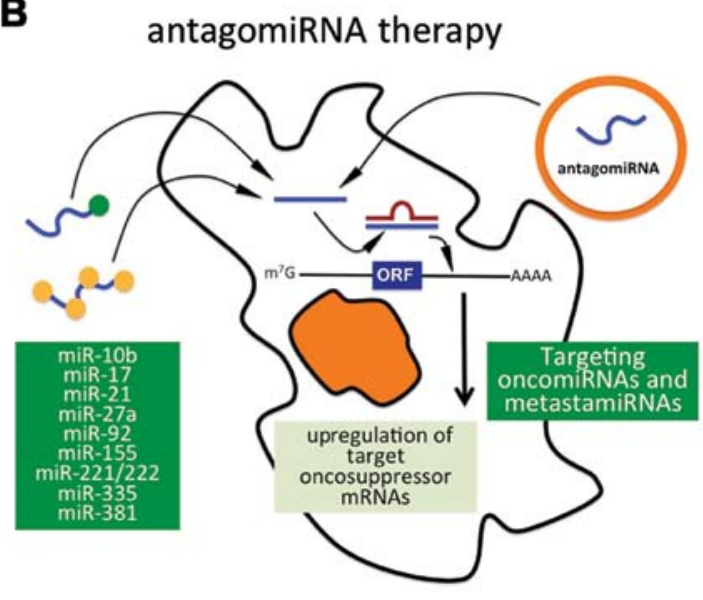

Fontana et al, 2008 (255)

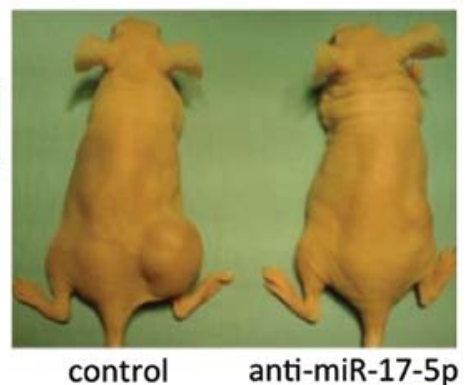

Figure 2. (A) miRNA replacement therapy: partial list of tumor suppressor miRNAs (in the blue box) and selected examples of the in vivo restoration of miR-29b (97) and of miR-30b (142), leading to the inhibition of tumor cell growth. (B) Targeting oncomiRNAs and metastamiRNAs with antagomiRNAs: partial list of onco/ metastamiRNAs and a selected example of the antitumor effects of antagomiR-17-5p (255). 
Table III. miRNAs promoting metastasis

\begin{tabular}{|c|c|c|c|c|}
\hline MicroRNA & Disease & Biological effects & $\begin{array}{l}\text { Target mRNA/ } \\
\text { pathway }\end{array}$ & Authors/(Refs.) \\
\hline miR-9 & $\begin{array}{l}\text { Breast, } \\
\text { colon cancer }\end{array}$ & $\begin{array}{l}\text { Promotion of breast cancer } \\
\text { cell motility and invasiveness; } \\
\text { enhancement of squamous cell } \\
\text { carcinoma CSC expansion } \\
\text { and metastasis }\end{array}$ & $\begin{array}{l}\text { CDH1, LIFR, } \\
\alpha \text {-catenin }\end{array}$ & $\begin{array}{l}\text { Ma et al (272); } \\
\text { Chen et al (273); } \\
\text { White et al (274) }\end{array}$ \\
\hline miR-10b & $\begin{array}{l}\text { Breast cancer, } \\
\text { glioblastoma }\end{array}$ & $\begin{array}{l}\text { Promotion of EMT, migration, } \\
\text { invasion and metastasis }\end{array}$ & $\begin{array}{l}\text { TP53, PAX6, NOTCH1, } \\
\text { HOXD10 }\end{array}$ & $\begin{array}{l}\text { Ma et al (275); } \\
\text { Lin et al (276) }\end{array}$ \\
\hline $\operatorname{miR}-15 b$ & Pancreatic cancer & Promotion of EMT & SMURF2 & Zhang et al (277) \\
\hline $\operatorname{miR}-19 \mathrm{a} / \mathrm{b}$ & Gastric cancer & $\begin{array}{l}\text { Facilitation of cell migration, } \\
\text { invasion and metastasis }\end{array}$ & MXD1 & Wu et al (278) \\
\hline miR-20a & $\begin{array}{l}\text { Cervical, } \\
\text { gallbladder } \\
\text { cancer }\end{array}$ & $\begin{array}{l}\text { Facilitation of cancer cell } \\
\text { proliferation and metastasis } \\
\text { in vitro and increased tumor } \\
\text { growth in vivo; induction of EMT }\end{array}$ & $\begin{array}{l}\text { ATG7, TIMP2, } \\
\text { Smad7 }\end{array}$ & $\begin{array}{l}\text { Chang et al (279); } \\
\text { Zhao et al (280) }\end{array}$ \\
\hline $\operatorname{miR}-21$ & $\begin{array}{l}\text { Breast, lung, brain, } \\
\text { cervical and colorectal } \\
\text { cancer, melanoma }\end{array}$ & $\begin{array}{l}\text { Drive to epithelial collective } \\
\text { cell migration, invasion, cell } \\
\text { metastasis and apoptosis; } \\
\text { enhancement of colorectal } \\
\text { cancer cell intravasion }\end{array}$ & $\begin{array}{l}\text { TPM1, PDCD4, } \\
\text { Maspin (SERPINB5), } \\
\text { PTEN, PI3K, Sprouty, } \\
\text { p53, cyclin D1, FOXO1, } \\
\text { FBXO11, TIPE2,MSH2, } \\
\text { hTERT, HIF1 } \alpha, \\
\text { TIMP3, APAF1 }\end{array}$ & $\begin{array}{l}\text { Zhu et al }(230) ; \\
\text { Dean et al }(281) ; \\
\text { Peacock et al }(282) ; \\
\text { Xu et al }(283) ; \\
\text { Asangani et al }(284) ; \\
\text { Hurst et al }(213) ; \\
\text { Melnik et al }(285)\end{array}$ \\
\hline miR-96 & Prostate cancer & $\begin{array}{l}\text { Bone metastasis, enhanced } \\
\text { effects on cellular } \\
\text { growth and invasiveness }\end{array}$ & $\begin{array}{l}\text { TGF- } \beta / \mathrm{mTOR} \\
\text { signaling }\end{array}$ & Siu et al (237) \\
\hline miR-105 & Breast cancer & $\begin{array}{l}\text { Destruction of the integrity } \\
\text { of vascular endothelial } \\
\text { barriers to promote metastasis }\end{array}$ & $\mathrm{ZO}-1$ & Zhou et al (286) \\
\hline $\operatorname{miR}-122$ & Breast cancer & $\begin{array}{l}\text { Promotion of metastatic } \\
\text { colonization }\end{array}$ & PKM2, & Fong et al (287) \\
\hline $\operatorname{miR}-135 b$ & Lung cancer & $\begin{array}{l}\text { Promotion of cell migration, } \\
\text { invasion and metastasis }\end{array}$ & $\begin{array}{l}\text { LATS2, TrCP, } \\
\text { NDR2, LZTST1 }\end{array}$ & Lin et al (288) \\
\hline $\operatorname{miR}-181 \mathrm{a}$ & Breast cancer & $\begin{array}{l}\text { Promotion of breast } \\
\text { cancer metastasis }\end{array}$ & Bim/TGF- $\beta$ & Taylor et al (289) \\
\hline $\operatorname{miR}-182$ & $\begin{array}{l}\text { Gallbladder, } \\
\text { sarcoma, } \\
\text { lung cancer }\end{array}$ & $\begin{array}{l}\text { Promotion of metastasis, } \\
\text { circulating tumor cells (CTC); } \\
\text { regulation of intravasion }\end{array}$ & $\begin{array}{l}\text { CADM1, RSU1, } \\
\text { MTSS1, PAI1, TIMP1 }\end{array}$ & $\begin{array}{l}\text { Qiu et al (290); } \\
\text { Sachdeva } \text { et al (239) }\end{array}$ \\
\hline $\operatorname{miR}-183$ & $\begin{array}{l}\text { Oesophageal } \\
\text { carcinoma }\end{array}$ & $\begin{array}{l}\text { Promotion of proliferation } \\
\text { and invasion }\end{array}$ & PDCD4 & Ren et al (291) \\
\hline miR-200s & $\begin{array}{l}\text { Breast, ovarian } \\
\text { cancer }\end{array}$ & $\begin{array}{l}\text { Activation of invasion } \\
\text { and metastasis (but in other } \\
\text { cases inhibition) }\end{array}$ & $\begin{array}{l}\text { ZEB1, ZEB2, } \\
\text { SIP1, Sec23a }\end{array}$ & $\begin{array}{l}\text { Korpal et al }(292) ; \\
\text { Korpal et al }(293) ; \\
\text { Park et al (294); } \\
\text { Gregory et al }(295)\end{array}$ \\
\hline $\operatorname{miR}-214$ & $\begin{array}{l}\text { Lung } \\
\text { adenocarcinoma, } \\
\text { melanoma }\end{array}$ & $\begin{array}{l}\text { Promotion of migration, } \\
\text { invasion and resistance to anoikis } \\
\text { of melanoma cells in vitro } \\
\text { and the extravasation and } \\
\text { lung metastasis formation in vivo; } \\
\text { promotion of EMT and metastasis }\end{array}$ & $\begin{array}{l}\text { TFAP2C, } \\
\text { Sufu }\end{array}$ & $\begin{array}{l}\text { Penna et al (296); } \\
\text { Penna et al }(297) \text {; } \\
\text { Long et al }(298)\end{array}$ \\
\hline $\operatorname{miR}-296-3 p$ & Prostate cancer & Promotion of metastasis & ICAM1 & Liu et al (299) \\
\hline $\operatorname{miR}-296-5 p$ & Prostate cancer & $\begin{array}{l}\text { Promotion of growth and invasion, } \\
\text { metastatic progression, and } \\
\text { persistence of cancer-initiating cells }\end{array}$ & Numbl (Klf4 signaling) & Vaira et al (300) \\
\hline
\end{tabular}


Table III. Continued.

\begin{tabular}{|c|c|c|c|c|}
\hline MicroRNA & Disease & Biological effects & $\begin{array}{l}\text { Target mRNA/ } \\
\text { pathway }\end{array}$ & Authors/(Refs.) \\
\hline $\operatorname{miR}-362-5 p$ & $\begin{array}{l}\text { Hepatocellular } \\
\text { carcinoma }\end{array}$ & $\begin{array}{l}\text { Promotion of cell proliferation, } \\
\text { migration, invasion in vitro; and } \\
\text { tumor growth and metastasis in vivo }\end{array}$ & CYLD & Ni et al (301) \\
\hline $\operatorname{miR}-373$ & Breast cancer & Drives EMT and metastasis & TXNIP & Chen et al (302) \\
\hline miR-520c & $\begin{array}{l}\text { Fibrosarcoma, } \\
\text { benign prostatic } \\
\text { hyperplasia, } \\
\text { glioblastoma }\end{array}$ & $\begin{array}{l}\text { Promotion of migration } \\
\text { and metastasis }\end{array}$ & MT1-MMP & Lu et al (303) \\
\hline
\end{tabular}

Table IV. miRNA replacement therapy of cancer: selected examples.

\begin{tabular}{|c|c|c|c|c|}
\hline Tumor type & miRNA target & Modulated mRNA & Effects following miR treatement & Authors/(Refs.) \\
\hline Lung cancer & miR-34a & $\begin{array}{l}\text { Repression of c-Met, Bcl-2; } \\
\text { partial repression of CDK4 }\end{array}$ & Block of tumor growth & Wiggins et al (90) \\
\hline Colon carcinoma & miR-33a & Pim-1 & Reduced tumor proliferation & Ibrahim et al (91) \\
\hline Colon carcinoma & $\operatorname{miR}-145$ & c-Myc and ERK5 & $\begin{array}{l}\text { Reduced tumor proliferation } \\
\text { and increased apoptosis }\end{array}$ & Ibrahim et al (91) \\
\hline Lung cancer & miR-let7 & $\begin{array}{l}\text { Negative regulation of } \\
\text { the cell cycle oncogenes } \\
R A S, M Y C \text { and } H M G A 2\end{array}$ & Reduction of tumor growth & Trang et al (92) \\
\hline Acute leukemia & $\operatorname{miR}-27 a$ & Bax and Bad & $\begin{array}{l}\text { Inhibition of cell growth due, } \\
\text { at least in part, to increased } \\
\text { cellular apoptosis }\end{array}$ & Scheibner et al (94) \\
\hline CML cells & $\operatorname{miR}-33 a$ & Pim-1 & Decelerated cell proliferation & Thomas et al (95) \\
\hline $\begin{array}{l}\text { Oral squamous cell } \\
\text { carcinoma (OSCC) }\end{array}$ & miR-596 & LGALS3BP & Growth inhibition & Endo et al (96) \\
\hline $\begin{array}{l}\text { Non-small cell lung } \\
\text { adenocarcinomas, } \\
\text { A549 cells }\end{array}$ & $\operatorname{miR}-29 b$ & $\begin{array}{l}\text { CDK6, DNMT3B, } \\
\text { MCL-1 }\end{array}$ & $\begin{array}{l}\text { Inhibition of } \\
\text { tumorigenicity in vivo }\end{array}$ & Wu et al (97) \\
\hline $\begin{array}{l}\text { Acute myeloid } \\
\text { leukemia }\end{array}$ & $\operatorname{miR}-29 b$ & $\begin{array}{l}\text { Downregulation of } \\
\text { DNMTs, CDK6, } \\
\text { SP1, KIT and FLT3 }\end{array}$ & $\begin{array}{l}\text { Decreased AML cell growth and } \\
\text { impairement of colony formation; } \\
\text { longer survival of treated mice; } \\
\text { improvement of antileukemic } \\
\text { activity of decitabine }\end{array}$ & Huang et al (98) \\
\hline $\begin{array}{l}\text { Laryngeal } \\
\text { carcinoma }\end{array}$ & miR-30b & p53 via MDM2 & $\begin{array}{l}\text { Antitumor and pro-apoptotic } \\
\text { effect in vivo and in vitro }\end{array}$ & Li and Wang (142) \\
\hline Breast cancer & miR-302 & AKT1 and RAD52 & $\begin{array}{l}\text { Sensitized radioresistant breast } \\
\text { cancer cells to ionizing radiation }\end{array}$ & Liang et al (99) \\
\hline
\end{tabular}

anti-miR-21-treated HCC cells. Furthermore, the ablation of miR-21 activity resulted in the inhibition of HCC cell migration and in the suppression of clonogenic growth (317).

In another study, using PNAs as anti-miRNA molecules, Fabani et al (318) targeted miR-155, demonstrating the deregulation of mRNA Bat5, Sfp1 and Jarid2. In our laboratory, Brognara et al analyzed the effects of PNAs targeting miR-221 on breast cancer cells (319). In order to maximize uptake in target cells, a polyarginine-peptide (R8) was conjugated, generating an anti-miR-221 PNA displaying very high affinity for RNA and efficient uptake within target cells without the need for transfection reagents. Targeting miR-221 with this PNA molecule resulted in i) a specific decrease in the hybridization levels of miR-221 measured by RT-qPCR, ii) the upregulation of 
Table V. AntagomiR-based miRNA targeting therapy of cancer: selected examples.

\begin{tabular}{|c|c|c|c|c|}
\hline Cells/tissues & miRNA target & Modulated mRNA & Effects following antagomiR treatment & Authors/(Refs.) \\
\hline Neuroblastoma & $\operatorname{miR}-17$ & $\mathrm{p} 21, \mathrm{BIM}$ & $\begin{array}{l}\text { Strongly increase of in vitro and } \\
\text { in vivo tumorigenesis }\end{array}$ & Fontana et al (255) \\
\hline $\begin{array}{l}\text { Human } \\
\text { glioblastoma }\end{array}$ & $\operatorname{miR}-27 a$ & FOXO3a & $\begin{array}{l}\text { Suppression of U87 growth } \\
\text { in vitro and in vivo }\end{array}$ & Ge et al (309) \\
\hline $\begin{array}{l}\text { Malignat } \\
\text { astrocytoma cells }\end{array}$ & $\operatorname{miR}-335$ & Daam1 & $\begin{array}{l}\text { Growth arrest, cell apoptosis, } \\
\text { invasion repression and marked } \\
\text { regression of astrocytoma xenografts }\end{array}$ & Shu et al (310) \\
\hline $\begin{array}{l}\text { Cutaneous } \\
\text { squamous cell } \\
\text { carcinoma (SCC) }\end{array}$ & $\operatorname{miR}-155$ & CDC73 & $\begin{array}{l}\text { Decreased cell viability, increased } \\
\text { apoptosis, and marked regression } \\
\text { of xenografts in nude mice }\end{array}$ & Rather et al (311) \\
\hline Neuroblastoma & miR-92 & DKK3 & $\begin{array}{l}\text { Increases release of the tumor suppressor } \\
\text { Dickkopf-3 (DKK3), a secreted protein } \\
\text { of the DKK family of Wnt regulators }\end{array}$ & Haug et al (312) \\
\hline Glioma & $\operatorname{miR}-381$ & LRRC4 & Decreased cell proliferation and tumor growth & Tang et al (313) \\
\hline Breast cancer & $\operatorname{miR}-10 b$ & Hoxd10 & Suppression of formation of lung metastases & Ma et al (314) \\
\hline Prostate cancer & $\mathrm{miR}-221 / \mathrm{miR}-222$ & $\mathrm{p} 27$ & Reduction of tumor growth & Mercatelli et al (315) \\
\hline Pancreatic cancer & miR-221/miR-21 & $\begin{array}{l}\text { SOCS6, SMAD7, } \\
\text { CDK6, KLF12, } \\
\text { MAPK10 }\end{array}$ & $\begin{array}{l}\text { Modulation of tumorigenesis, } \\
\text { metastasis, and chemotherapy } \\
\text { resistance in stem-like cells }\end{array}$ & Zhao et al (316) \\
\hline
\end{tabular}

p27 ${ }^{\text {Kipl }}$ mRNA and protein expression, measured by RT-qPCR and western blot analysis, respectively. As regards the in vivo effects of anti-miRNA therapy, Yan et al (320) addressed the potential effects of PNA-anti-miR-21 in vivo on the growth of breast cancer cells. In their experiments, MCF-7 cells treated with PNA-anti-miR-21 or PNA-control were subcutaneously injected into female nude mice and detectable tumor masses were observed in few mice in the MCF/PNA-anti-miR-21 group, while much larger tumors were detected in all mice in the $\mathrm{MCF} / \mathrm{PNA}$-control group. Both tumor weight and number showed that $\mathrm{MCF} / \mathrm{PNA}$-control cells formed larger tumors more rapidly than MCF/PNA-anti-miR-21 cells in nude mice. As a final example, Cheng et al (57) demonstrated that the PNA anti-miRs with a peptide with a low $\mathrm{pH}$-induced transmembrane structure (pHLIP) target the tumor microenvironment, transport anti-miRs across plasma membranes under acidic conditions, such as those found in solid tumors and effectively inhibit the miR-155 oncomiR in a mouse model of lymphoma.

\section{MicroRNAs and epithelial-mesenchymal transition}

EMT is a powerful process in tumor invasion, metastasis and tumorigenesis, and describes the molecular reprogramming and phenotypic changes that are characterized by a transition from polarized immotile epithelial cells to motile mesenchymal cells (Fig. 3). This process is characterized by the loss of polarity and cell-cell contacts by the differentiated epithelial cells, with deep alterations occurring at the level of tight junctions and desmosomes. The breach of the basement membrane is a following step, leading to the invasion of blood and/or lymphatic vessels by these mesenchymal differentiated cancer cells, which at the end of the process, causes migration, often accompanied by drug resistance (Fig. 3). It is now well-known that several miRNAs are important regulators of EMT. Some of these are miR-7, miR-17/20, miR-22, miR-30, miR-200 and its family members. Most of these miRNAs potentiate EMT, while some well-characterized miRNAs play a suppressive role in EMT. For instance, the metastasis suppressor role of the miR-200 members is strongly associated with the inhibition of EMT. This is well described in the published review by Zhang and Ma (321), and in the studies by Zaravinos et al (322) and Kiesslich et al (323), showing the most recent advances regarding the influence of miRNAs in EMT and the regulatory effects they exert on major signaling pathways in various types of cancer (Fig. 3). In Caski cervical cancer cells, the oncomiR-155 acts as a tumor suppressor and suppresses EGF-induced EMT, decreasing migration/invasion capacities, inhibiting cell proliferation and enhancing the chemosensitivity to DDP in humans (324). Chang et al (279) demonstrated that the overexpression of miR-20a in gallbladder carcinoma cells induced EMT and promoted metastasis via the direct inhibition of Smad7, correlating this miRNA with local invasion, distant metastasis and a poor prognosis in patients with gallbladder carcinoma.

In the ovarian surface epithelium, EMT is considered the key regulator of the post-ovulatory repair process and it can be triggered by a range of environmental stimuli. The aberrant expression of the miR-200 family (miR-200a, miR-200b, miR-200c, miR-141 and miR-429) in ovarian cancer, and its involvement in the initiation and progression of ovarian cancer have been well demonstrated. The miR-200 family members seem to be strongly associated with EMT and to have a 


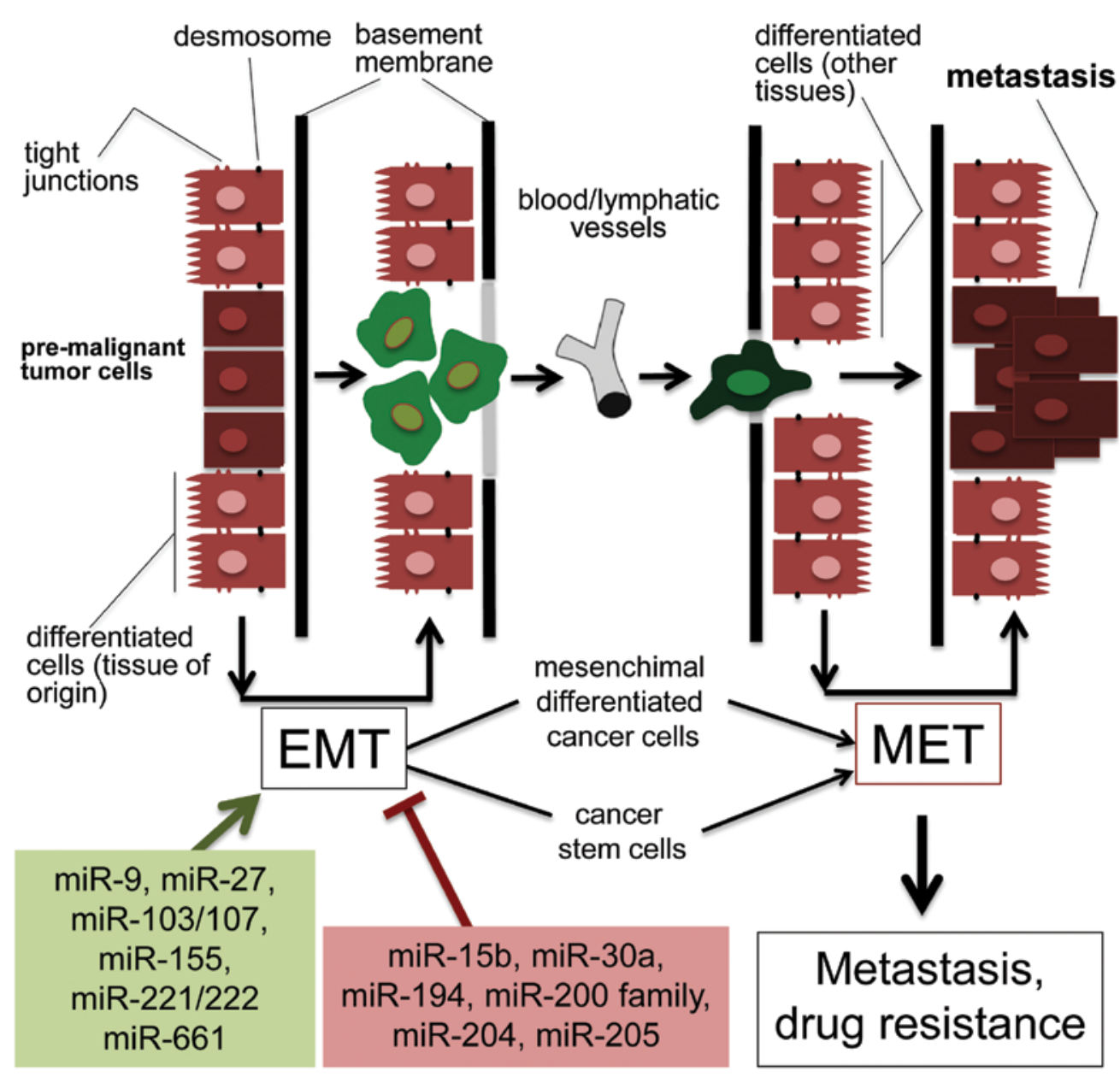

Figure 3. Epithelial-mesenchymal transition (EMT), a powerful process leading to tumor invasion and metastasis. Examples of EMT-promoting miRNAs are reported in the green box, while examples of EMT-interfering miRNAs are reported in the pink box. Modified from Kiesslich et al (323).

metastasis suppressor role. miRNA signatures can accurately distinguish ovarian cancer from the normal ovary and can be used as diagnostic tools to predict the clinical response to chemotherapy. Recent evidence suggests a growing list of novel miRNAs (miR-187, miR-34a, miR-506, miRNA-138, miR-30c, miR-30d, miR-30e-3p, miR-370 and miR-106a, among others) that are also implicated in ovarian cancer-associated EMT, either enhancing or suppressing it. MicroRNA-based gene therapy provides a prospective antitumor approach for integrated cancer therapy (325).

As regards the molecular targets of EMT-regulating miRNAs, several are known and validated. Among these, transcription factors play a very important role. For instance, Gao et al (326) identified SOX2 as a key player in EMT, by examining the effects of its overexpression. They demonstrated that SOX2-overexpressing Eca-109 cells exhibited an enhanced cell migration/invasion capacity. Moreover, these cells exhibited characteristics of EMT, that is, a significantly suppressed expression of the epithelial cell marker with a concomitant enhancement in the expression of mesenchymal markers. An increased expression of Slug in SOX2-overexpressing cells suggested the involvement of this transcription factor in SOX2regulated metastasis. Finally, the expression levels of STAT3/ HIF-1 $\alpha$ were found to be upregulated in SOX2-expressing cells, and the blockade of these transcription factors resulted in the inhibition of Slug expression at both the protein and mRNA level.

Of interest, is also the finding that miR-221/222, which are involved in EMT as positive regulators, can be transcriptionally controlled by Slug. This was demonstrated by Lambertini et al (327), who showed that Slug silencing significantly decreased the level of miR-221, strongly suggesting that miR-221 is a Slug target gene. This was further confirmed by the characterization of a specific region of the miR-221 promoter that is transcriptionally active and is bound by the transcription factor Slug in vivo.

On the other hand, various miRNAs have been reported to directly target EMT-promoting transcription factors. For instance Qiu et al (328) found that miR-139-5p functions as a suppressor of EMT in HCC and metastasis by targeting ZEB1 and ZEB2, and that it may be a therapeutic target for metastatic HCC. In conclusion, miRNAs targeting and miRNA mimicking strategies are both expected to be suitable for the control of EMT.

\section{MicroRNAs and neoangiogenesis}

A very important step in tumor dissemination and metastasis is neoangiogenesis. This is a very complex process in which several proteins and protein networks participate, for instance 
interleukin (IL)-8, vascular endothelial growth factor (VEGF), basic fibroblast growth factor (bFGF), angiopoietins and matrix metalloproteinases (MMPs). As far as the expression of the IL-8 gene is concerned, the increase in IL-8 gene expression from the healthy brain to low-grade glioma (LGG) can be explained by alterations in the regulatory networks associated with IL-8 gene transcription. Among these, the nuclear factor $-\kappa \mathrm{B}(\mathrm{NF}-\kappa \mathrm{B})$ network should be proposed, since i) $\mathrm{NF}-\kappa \mathrm{B}$ is one of the major transcription factors involved in IL-8 gene regulation (329); ii) $\mathrm{NF}-\kappa \mathrm{B}$ is a marker of glioma onset and progression (330-333); iii) miR-16 inhibits glioma cell growth through the suppression of the NF- $\kappa \mathrm{B}$ signaling pathway (334). In addition to transcription factors, miRNAs can directly modulate pro-angiogenic factors. For instance, the increased IL-8 gene expression in high-grade glioma (HGG; with respect to LGG) may be associated with decrease of its inhibitory miRNA, miR-93, at least in a subset of HGG patients. The decrease in miR-93 expression in these HGG patients, in addition to IL-8, may lead to the post-transcriptional upregulation of VEGF, monocyte chemoattractant protein-1 (MCP-1) and platelet-derived growth factor (PDGF)-bb, well recognized markers of the late tumor stages of gliomas (335-337). However, it should be mentioned that HGG samples are highly heterogeneous with respect to miR-93 levels, suggesting the involvement of multiple regulatory pathways in controlling the level of IL-8 gene expression.

\section{Selected examples of miRNA therapeutics: mimicking miR-124}

One of the better described examples of tumor suppressor miRNAs is miR-124. This miRNA has been found to play a significant role in several types of cancer $(168-173,338)$. Specifically, miR-124 expression is reportedly downregulated in the cells and tissues of esophageal cancer (339), breast cancer (340), renal cell carcinoma (341) and CRC (172). Accordingly, the ectopic expression of miR-124 by target tumor cells inhibits tumor-related parameters in experimental model systems mimicking prostate cancer, medulloblastoma, hepatocellular carcinoma, gastric cancer, glioma, osteosarcoma and CRC.

For instance, Taniguchi et al (164) recently demonstrated that the ectopic expression of miR-124 induced apoptosis and autophagy in colon cancer cells. In addition, miR-124 was demonstrated to target polypyrimidine tract-binding protein 1 (PTB1), which is a splicer of pyruvate kinase muscles 1 and 2 (PKM1 and PKM2), and to induce the switching of PKM isoform expression from PKM2 to PKM1 (164). In addition to this study, Lu et al (342) demonstrated that miR-124a expression was downregulated in human glioma tissues, and that its expression level negatively correlated with the pathological grade of the glioma. The restoration of miR-124a inhibited glioma cell proliferation and invasion in vitro.

Furthermore, they found that miR-124a directly targeted and suppressed IQ motif containing GTPase activating protein 1 (IQGAP1), a well-known regulator of actin dynamics and cell motility (342). Taken together all these data clearly demonstrate that miR-124a is an important tumor suppressor miRNA which is downregulated in cancer cells; accordingly antitumor effects can be achieved following the administration of miR-124, pre-miR-124 or a variety of miR-124 mimics to cancer cells.

Finally, the translational relevance of the role of miR-124 in antitumor drug sensitivity is suggested by the finding that the increased miR-124 expression correlates with an improved breast cancer prognosis, specifically in patients receiving chemotherapy. This finding suggests that miR-124 may potentially be used as a therapeutic agent to improve the efficacy of chemotherapy, including that based on DNA-damaging agents via ATM interactor (ATMIN)- and poly(ADP-ribose) polymerase 1 (PARP1)-mediated mechanisms (343).

\section{Selected examples of miRNA therapeutics: mimicking miR-93}

A second example of possible miRNA replacement therapy is based on the inhibition of IL- 8 and VEGF by the transfection of tumor target cells with pre-miR-93. This was performed in human glioma cell lines (U251 and T98G), as well as on the SK-N-AS neuroblastoma cell line.

The first conclusion of this research activity is that the miRNA, miR-93, is involved in the control of the expression of the IL-8 gene in the glioma U251 and in the neuroblastoma SK-N-AS cell lines $(344,345)$. The effects of these treatments were analyzed by RT-qPCR (looking at the IL-8 mRNA content) or by Bio-plex analysis (looking at IL-8 protein secretion). In addition, Fabbri et al (344) found that the transfection of target cells with pre-miR-93 led to the downregulation of VEGF (see the results depicted in Fig. 4A), suggesting that, as shown in Fig. 4B, miR-93 has effects on the growth of gliomas [by interfering with growth factors, including PDGF, fibroblast growth factor (FGF), granulocyte-macrophage colony-stimulating factor (GM-CSF) and granulocyte-colony stimulating factor(G-CSF)], as well as on neoangiogenesis.

\section{Selected examples of anti-miRNA therapeutics: targeting miR-221/222}

Gliomas, as other tumors, express miR-221 at high levels, promoting malignant progression through activation of the Akt pathway and the inhibition of p27 ${ }^{\mathrm{Kip} 1}$ (346-349). In addition miR-221 mediates the downregulation of other genes, such as PUMA (258), intercellular adhesion molecule 1 (ICAM-1) (350), TIMP metallopeptidase inhibitor 3 (TIMP3) (351) and phosphatase and tensin homolog (PTEN) (352), and may thus be associated with cancer onset and progression (353). Therefore, miR-221 appears to be a specific target for the treatment of gliomas $(354,355)$. Zhang et al (354) reported that the co-suppression of the miR-221/222 cluster suppressed human glioma cell growth by affecting $\mathrm{p} 27^{\mathrm{Kip} 1}$ expression in vitro and in vivo. In our own laboratory, we have also examined the effects of a PNA against miR-221 and showed that it is able to induce a sharp decrease in miR-221 biological activity. The employed PNA carryed an $\operatorname{Arg}(8)$ peptide to facilitate PNA uptake by target cells. Two studies were published on this specific issue. In the first study by Brognara et al (319), we demonstrated that targeting miR-221 induced a sharp increase in the expression of the miR-221 target $\mathrm{p} 27^{\mathrm{Kip} 1} \mathrm{mRNA}$ in a breast cancer cell line (319). In a more recent study of ours, Brognara et al (56) 
A

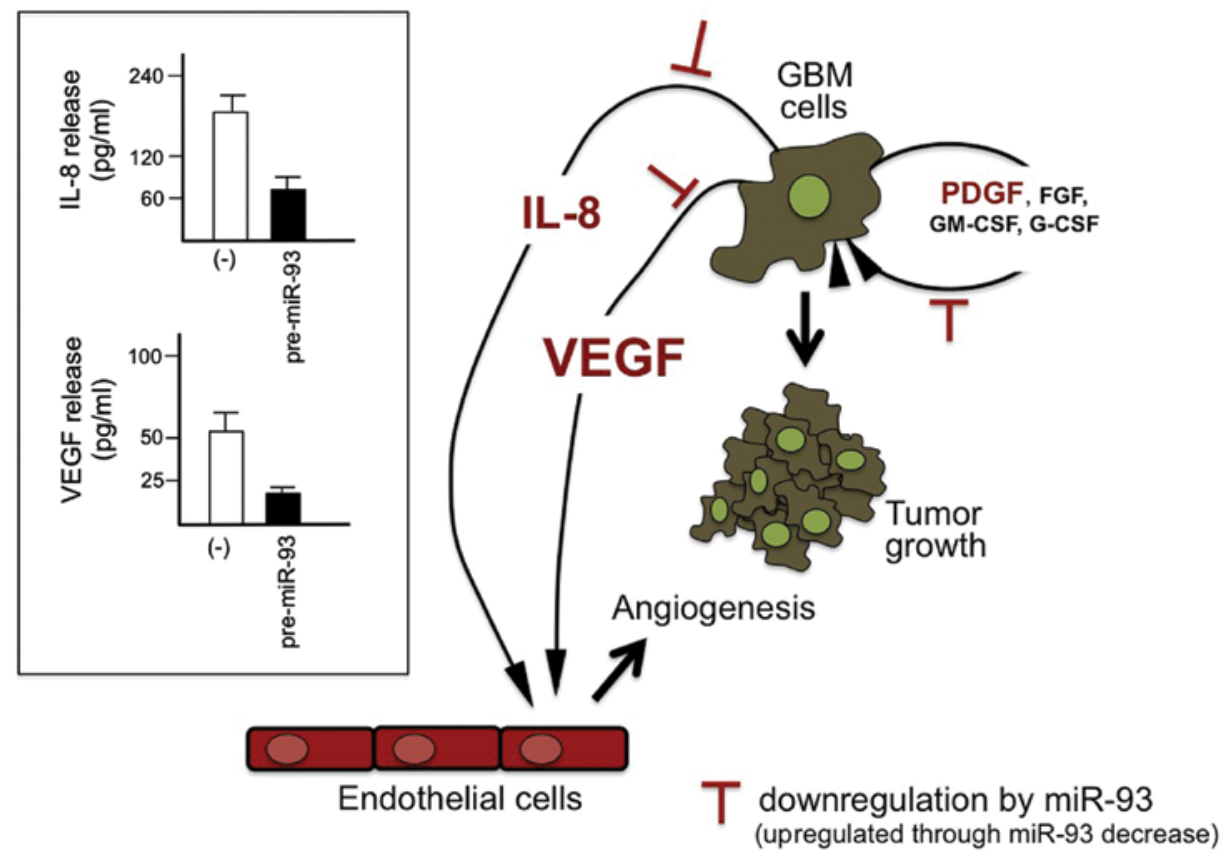

Figure 4. (A) Transfection of U251 glioma cells with pre-miR-93 leads to the downregulation of interleukin-8 (IL-8) (upper panel) and vascular endothelial growth factor (VEGF; lower panel) protein expression. (B) Scheme outlining the effects of pre-miR-93 on neoangiogenesis and tumor growth in gliomas. Modified from Fabbri et al (344).

demonstrated that the PNA against miR-221 can be internalized by glioma cells when linked to a $\operatorname{Arg}(8)$ tail (R8), leading to the inhibition of miR-221 functions, associated with the increased expression of $\mathrm{p} 27^{\mathrm{Kip} 1}$ in U251 and T98G cells. In addition, the expression of another miR-221 target gene, TIMP3, was upregulated following treatment of the T98G cells with R8-PNA-a221. These data support the concept that targeting miR-221 with antagomiR molecules may provide novel options for developing protocols for the treatment of gliomas. This is supported by the finding that the treatment of all the glioma cells lines with R8-PNA-a221 induced the activation of the early apoptotic pathway (56).

\section{Combined treatments: targeting multiple miRNAs}

Several tumors express upregulated levels of several miRNAs, suggesting that a possible limit to anti-mRNA therapeutics may be the requirement of the co-targeting of several miRNAs to obtain the programmed biological effects. Moreover, an important anti-miRNA strategy may be associated with the obvious need for the co-targeting of different miRNAs belonging to the same miRNA family.

miRNA-replacement therapy. Yang et al (356) found that the co-transfection of miR-137/197 resulted in a reduction in myeloid cell leukemia 1 (MCL-1) protein expression, as well as in the alteration of the expression of apoptosis-related genes, the induction of apoptosis, and in the inhibition of the viability, colony-forming ability and migration ability of multiple myeloma cells. MCL-1 was further validated as a direct target of miR-137/197. Conversely, the overexpression of MCL-1 partially reversed the effects of miR-137/197. Importantly, the in vivo lentiviral-mediated or intratumor delivery of miR-137/197 induced the regression of tumors in murine xenograft models of multiple myeloma (356).

Anti-miRNA therapy. The co-treatment of target cells with antagomiR molecules selective for different miRNAs has been recently described. For instance, Lee et al (357) investigated the role of miRNAs targeting runt related transcription factor 3 (RUNX3) in early tumorigenesis. Under hypoxic conditions, miR-130a and miR-495 are upregulated and target RUNX3 by binding to its 3'-UTR in gastric cancer cells. Using matrigel plug assay, they found that antagomiRs specific for miR-130a and miR-495 significantly reduced angiogenesis in vivo and hypothesized that the co-targeting of miR-130a and miR-495 may prove to be a potential therapeutic strategy with which to recover RUNX3 expression under hypoxic conditions and in early tumorigenesis (357).

In a recent study, Brognara et al (358) treated glioma cell lines with a combined administration of antagomiR-PNAs targeting miR-221 and miR-222. In fact, the same site recognized by miR-221 in the 3 'UTR of target mRNAs can be also identified by miR-222, as suggested by predicted molecular interactions using PUMA 3'UTR as a model system. Therefore, the targeting of miR-221 with antagomiRs may not be sufficient to achieve the complete suppression of miR-221 biological activity due to the presence of miR-222 in target cells. Since miR-221 and miR-222 belong to the same transcriptional unit and are, as expected, co-expressed in tumor cell lines (U251, U373 and T98G), Zhang et al (354) determined whether the co-administration of antagomiRs recognizing miR-221 and miR-222 would lead to a more efficient inhibitory activity on miR-221/222 dependent functions. The results obtained 
A

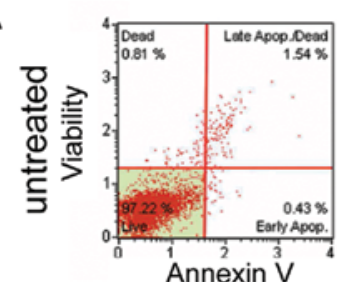

C

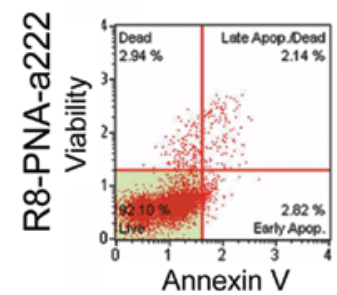

B

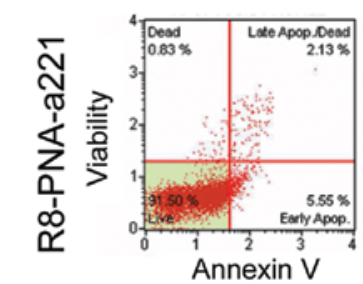

D

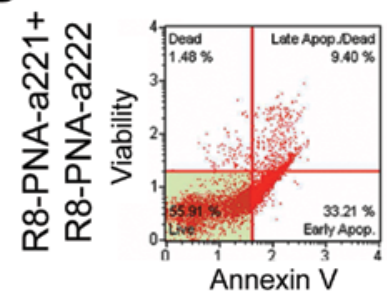

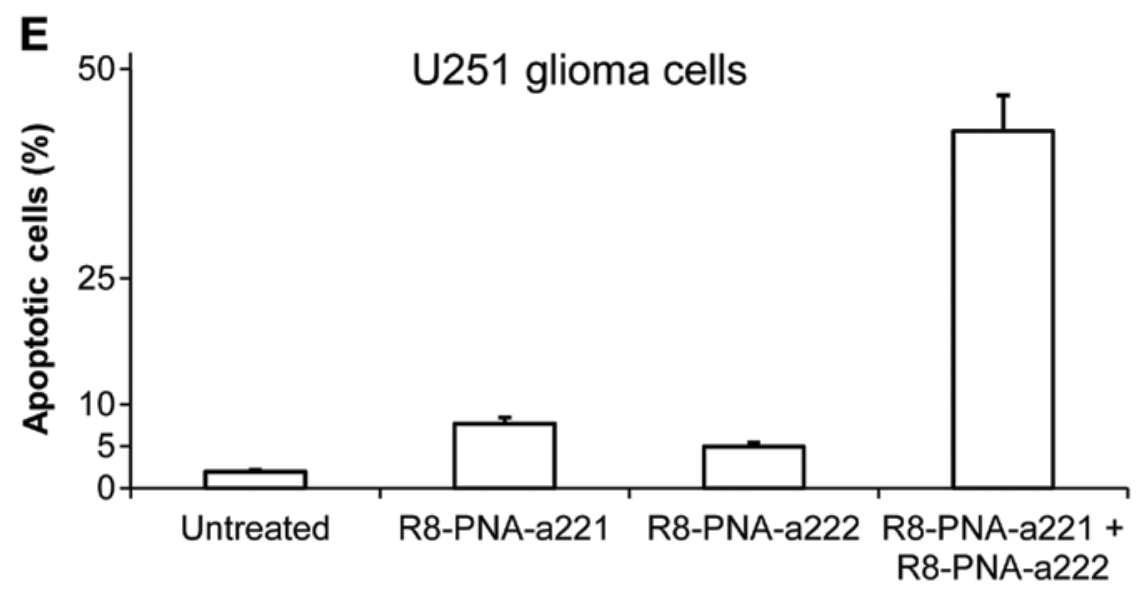

Figure 5. (A-D) Co-administration of R8-conjugated PNAs against miR-221 (R8-PNA-a221) and miR-222 (R8-PNA-a222) exhibits increased effects on the apoptosis of treated U251 glioma cells. Human glioma U251 cells were cultured (A) without, or (B) in the presence of $4 \mu$ M R8-PNA-a221, (C) $4 \mu$ M R8-PNA-a222 or (D) $2 \mu \mathrm{M}$ R8-PNA-a221 plus $2 \mu \mathrm{M}$ R8-PNA-a222. After $48 \mathrm{~h}$ of treatment, an analysis of the induction of apoptosis was conducted using the Annexin V assay and the Muse instrument, as described in detail in the study by Brognara et al (56). (E) Quantitative results derived by the data shown in (A-D). The most potent apoptosis-inducing effects were observed with the co-treatment of the U251 cells with R8-PNA-a221 and R8-PNA-a222. Modified from Brognara et al (358).

demonstrated that the co-suppression of miR-221/222 directly resulted in the upregulation of $\mathrm{p} 27^{\mathrm{Kip} 1}$ in the tested cells and in the inhibtion of cell growth by reducing a G1 to $\mathrm{S}$ shift in the cell cycle. Consistently, the knockdown of miR-221/222 through antisense 2 '-OME-oligonucleotides increased $\mathrm{p} 27^{\mathrm{Kip} 1}$ expression in mice with U251 glioma subcutaneous tumors and markedly reduced tumor growth in vivo through the upregulation of $\mathrm{p} 27^{\mathrm{Kip} 1}$ (354).

In our own laboratory, we have approached the same issue using PNAs. We have previously reported that a PNA targeting miR-221 can be internalized by glioma cells and exert biological effects on miR-221-dependent functions when it is linked to an octaarginine tail (R8) (56). The major results of the more recent study by Brognara et al (358) are the following: i) R8-conjugated PNAs against miR-221 (R8-PNA-a221) and miR-222 (R8-PNA-a222) exhibit selective biological activity on miR-221 and miR-222; ii) when R8-PNA-a221 and R8-PNA-a222 are singularly administered to glioma cells, the specific inhibition of hybridization to miR-221 and miR-222 is obtained following RT-qPCR analysis; iii) both R8-PNA-a221 and R8-PNA-a222 induce the apoptosis of U251, U373 and T98G glioma cells. Finally, the co-administration of
R8-PNA-a221 and R8-PNA-a222 was associated with the most prominent effects of this treatment in inducing apoptosis (see the representative experimental results shown in Fig. 5) (358).

\section{Combined treatments: co-administration of antitumor drugs and miRNA therapeutic agents}

One of the most interesting results obtained to date using miRNA therapeutics is the formal demonstration that, when used in combination with antitumor drugs, satisfactory therapeutic effects may be achieved (359). This has been demonstrated using both miRNA mimicking approaches, as well as anti-miRNA molecules.

miRNA replacement therapy. Gao et al (360), demonstrated that clear-cell renal cell carcinoma is a tumor type which is highly resistant to treatment and that the miR-200 family was involved in the process of mesenchymal-epithelial transition (MET) during renal development. In their study, evidence was provided to indicate that miR-200c sensitizes ccRCC cells to sorafenib or imatinib to inhibit cell proliferation. The combined application of chemotherapeutic drugs and 
miR-200c may enhance the efficacy of therapy by promoting both apoptosis and autophagy (360). Another study demonstrating the enhanced effects of the combination of miRNA replacement therapy with antitumor drugs was published by Huang et al (98) with a novel transferrin-conjugated nanoparticle delivery system for synthetic miR-29b (Tf-NP-miR-29b), designed for intervention in the treatment of acute myeloid leukemia (AML). The antileukemic activity of Tf-NP-miR-29b was evaluated by measuring cell proliferation and colonyforming ability in vitro, as well as in vivo using a leukemia mouse model system. Tf-NP-miR-29b treatment significantly downregulated miR-29b targets, such as DNA methyltransferases (DNMTs), CDK6, specificity protein 1 (SP1), KIT and Fms-related tyrosine kinase 3 (FLT3), decreased AML cell growth and impaired colony formation. Mice engrafted with AML cells and then treated with Tf-NP-miR-29b had a significantly longer survival compared with the mice treated with Tf-NP-scramble or free miR-29b. Furthermore, priming AML cells with Tf-NP-miR-29b before treatment with decitabine resulted in a marked decrease in cell viability in vitro and enhanced the antileukemic activity compared to treatment with decitabine alone in vivo, suggesting that miRNA replacement therapy based on the delivery of miR-29b can be proposed for AML therapy also in combination with antitumor drugs.

Moreover, the study by Pogribny et al (361) reported that miR-7 expression directly targeted and significantly inhibited multidrug resistance-associated protein 1 (MPR1), which enhanced sensitivity to cisplatin in cisplatin-resistant breast cancer. Furthermore, an in vitro study by Suto et al (362) demonstrated that miR-7 overexpression enhanced sensitivity to cetuximab and suppressed cell proliferation after treatment with cetuximab in HCT-116 and SW480 cetuximab-resistant CRC cells. Additionally, miR-7 was found to enhance the sensitivity of non-small cell lung cancer (NSCLC) to paclitaxel (PTX) by promoting PTX-induced apoptosis (363). Another recent study demonstrated that the restoration of miR-143 and miR-145 expression in mutant KRAS (HCT116 and SW480) and wild-type KRAS (SW48) colon cancer cells re-sensitized the colon cancer cells to cetuximab by promoting cetuximab-mediated antibody-dependent cellular cytotoxicity (ADCC) to induce cell death (364).

In our own laboratory, we further analyzed the possible co-admistration of temozolomide (TMZ) and the tumor suppressor pre-miR-124. This was investigated in one neuroblastoma and two glioma cell lines. For miRNA replacement, we employed transfection with pre-miR-124, since miR-124 is a powerful tumor suppressor pro-apoptotic miRNA. In order to demonstrate the activity of the combined treatment, the antiproliferative and pro-apoptotic effects were analyzed. This set of data confirm that miRNA therapeutics can be successfully combined with chemical treatments to obtain greater effects with low doses of reagents. In conclusion, our data showed that, in addition to the combinations between antitumor drugs and antagomiR-based protocols, interesting results can be obtained by the combination of drugs with miRNA replacement agents (Fabbri et al, unpublished data).

Anti-miRNA therapy. As regards the use of anti-miRNA molecules, Costa et al (365) developed an efficient delivery system for anti-miR-21 oligonucleotides, showing preferential accu- mulation within brain tumors and efficient miR-21 silencing, which resulted in increased mRNA and protein levels of the miR-21 target RhoB. Decreased tumor cell proliferation and tumor size, as well as enhanced apoptosis and, to a lesser extent, the improvement of animal survival, were observed in glioblastoma tumor-bearing mice upon the systemic delivery of targeted nanoparticle-formulated anti-miR-21 oligonucleotides and exposure to the tyrosine kinase inhibitor, sunitinib (365). Although further studies are warranted to demonstrate a therapeutic benefit in the clinical context, these findings suggest that miRNA modulation by targeted nanoparticles combined with anti-angiogenic chemotherapy may hold promise as an attractive therapeutic approach. Other studies have reported that the downregulation of miR-21 can induce cell apoptosis and reverse drug resistance in cancer treatments; a synergistic antiproliferative and pro-apoptotic activity was obtained using combined treatment, based on anti-miR-21 molecules and temozolomide (366) or doxorubicin (367) in human glioma cell lines. In our own laboratory, we determined whether the treatment of T98G cells with R8-PNA-a221 or R8-PNA-a222 reverses the resistance of the cells to apoptosis induced by TMZ and found that when R8-PNA-a221 and R8-PNA-a222 are co-administered, the reversion of TMZ resistance was much more efficient as opposed to single treatments (358).

A recent study reported the co-delivery of antagomiR-10b and PTX by a liposomal delivery and showed that it efficiently inhibited tumor growth and reduced the incidence of lung metastasis. In fact, antagomiR-10b impeded the migration of $4 \mathrm{~T} 1$ cells in vitro, silencing miR-10b and upregulating Hoxd10 both in vitro and in vivo, while PTX elicited potent tumor cell inhibitory effects (368). The same antitumor efficacy and delivery to the tumor site may be achieved by the dual loading of miR-218 mimic (bio-drug) and temozolomide (chemo-drug) using a new delivery nanogel system approach (369).

\section{Combining miRNA replacement strategies with anti-miRNAs and siRNA molecules}

Xue et al (370) verified the biological activity of novel lungtargeting nanoparticles capable of delivering miRNA mimics and siRNAs to lung adenocarcinoma cells in vitro and to tumors in a genetically engineered mouse model of lung cancer based on the activation of oncogenic Kirsten rat sarcoma viral oncogene homolog (Kras) and the loss of p53 function. The therapeutic delivery of miR-34a, a p53-regulated tumor suppressor miRNA, restored the miR-34a levels in lung tumors, specifically downregulated miR-34a target genes, and attenuated tumor growth. The delivery of siRNAs targeting Kras reduced Kras gene expression and MAPK signaling, increased apoptosis and inhibited tumor growth. The combination of miR-34a and siRNA targeting Kras improved the therapeutic responses as compared to those observed with either small RNA alone, leading to tumor regression. Furthermore, nanoparticle-mediated small RNA delivery plus conventional, cisplatin-based chemotherapy prolonged survival in this model compared to chemotherapy alone. These findings demonstrate that RNA combination therapy is possible in a model of lung cancer and provide preclinical support for the use of small RNA therapies in patients who have cancer (370). A second 
A

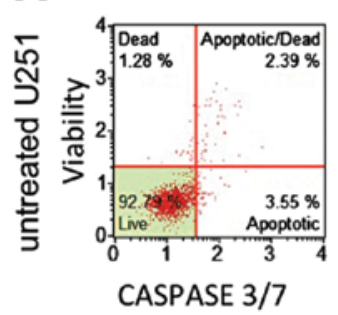

C

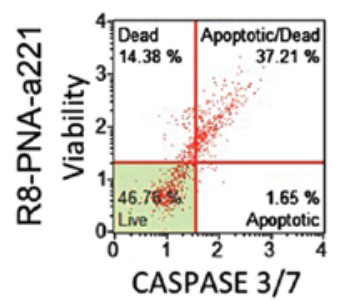

B

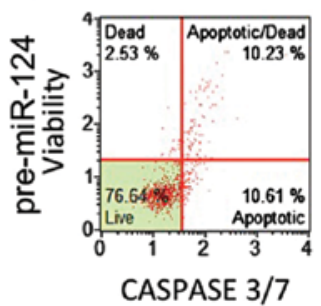

D

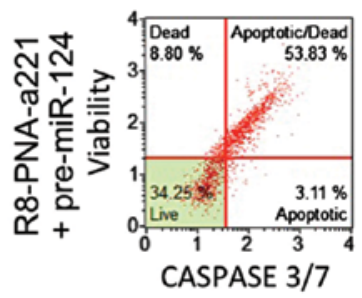

$\mathbf{E}$

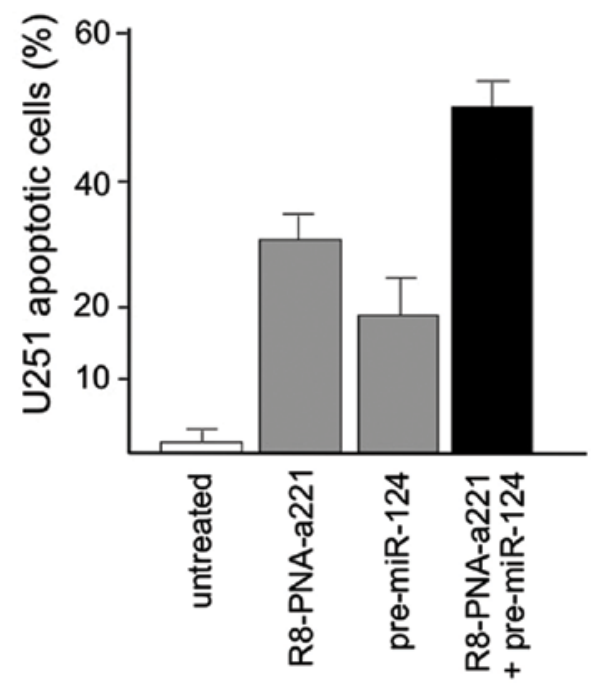

Figure 6. Treatment of U251 glioma cells with (B) $10 \mathrm{nM}$ pre-miR-124, (C) $4 \mu \mathrm{M}$ R8-PNA-a221 targeting miR-221 or (D) a combined administration of $10 \mathrm{nM}$ pre-miR-124 and $4 \mu \mathrm{M}$ R8-PNA-a221. (A) Control untreated cells are shown. After $48 \mathrm{~h}$ of treatment, the effects on apoptosis were analyzed by the caspase-3/7 assay and the Muse instrument. (E) Quantitative results derived by the data shown in (A-D). The most potent apoptosis-inducing effects were observed with the co-treatment of U251 cells with R8-PNA-a221 and pre-miR-124 (Fabbri et al, unpublished data).

example is that published by Nishimura et al (371) who first demonstrated that the siRNA-mediated silencing of EphA2, an ovarian cancer oncogene, resulted in the reduction of tumor growth. Second, they presented evidence that the additional inhibition of EphA2 by an miRNA further 'boosts' its antitumor effects. They identified miR-520d-3p as a tumor suppressor upstream of EphA2. The restoration of miR-520d-3p prominently decreased EphA2 protein levels, and suppressed tumor growth and migration/invasion both in vitro and in vivo. The dual inhibition of EphA2 in vivo using nanoliposomes loaded with miR-520d-3p and EphA2 siRNA exhibited synergistic antitumor efficiency and greater therapeutic efficacy than either monotherapy alone. These data emphasize the feasibility of combined miRNA-siRNA therapy, and will have broad implications for innovative gene silencing therapies for cancer and other diseases.

A further example in this very exciting field of investigation was reported by $\mathrm{Hu}$ et al (372), studying Bcl-2, a prominent member of the Bcl-2 family of proteins that regulate the induction of apoptosis. They investigated the effect of Bcl-2 siRNAs combined with miR-15a oligonucleotides on the growth of Raji cells. Following transfection of these combined reagents, the protein and mRNA levels of Bcl-2 were markedly decreased. The growth of the cells was significantly inhibited compared with the cells transfected with Bcl-2 siRNA or miR-15a alone and the apoptotic rate significantly increased. These results suggest that the combination of Bcl-2 siRNA and miR-15a oligonucleotides increases the apoptosis of Raji cells, and strongly support the concept that the combination of Bcl-2 siRNA and miR-15a may be a useful approach in the treatment of lymphoma.

Finally, an example of possible combined treatment is shown in Fig. 6, which indicates that the co-treatment of U251 cells with PNAs targeting miR-221 or miR-222 in the presence of pre-miR-124 transfection leads to a much higher level of apoptosis as opposed to singularly administered reagents (Fabbri et al, unpublished data).

\section{Conclusion}

MicroRNA therapeutics in cancer are based on targeting or mimicking miRNAs involved in cancer onset, progression, angiogenesis, EMT and metastasis. This strategy has been proposed several years ago and is based on the well-recognized fact that miRNAs play a key role in the post-transcriptional control of gene expression by the sequence-selective targeting of mRNAs and are key players in several biological functions and pathological processes, including cancer. In this respect, several studies have conclusively demonstrated that miRNAs are deeply involved in tumor onset and progression, either behaving as tumor-promoting miRNAs (oncomiRNAs and metastamiRNAs) or as tumor suppressor miRNAs. In general, miRNAs able to promote cancer target mRNAs coding for tumor suppressor proteins, whereas miRNAs exhibiting tumor suppressor properties usually target mRNAs coding oncoproteins. This has a very important implication in diagnosis and/ or prognosis, including the recent discovery that the pattern of circulating cell-free miRNAs in serum allows us to perform molecular analyses on these non-invasive liquid biopsies. This research field has confirmed that cancer-specific miRNAs are present in extracellular body fluids, and may play a very important role in the crosstalk between cancer cells and surrounding normal cells. Interestingly, the evidence of the presence of miRNAs in serum, plasma and saliva supports their potential as an additional set of biomarkers for cancer.

This review has focused on the most promising examples potentially leading to the development of anticancer, miRNAbased therapeutic protocols. The inhibition of miRNA activity can be readily achieved by the use of miRNA inhibitors and oligomers, including RNA, DNA, DNA analogues (miRNA antisense therapy), small molecule inhibitors, miRNA sponges or through miRNA masking. On the contrary, the enhancement of miRNA function (miRNA replacement therapy) can be achieved by the use of modified miRNA mimetics and 
plasmids or lentiviral vectors carrying miRNA sequences However, we should carefully consider that a single miRNA can target several mRNAs (not only tumor-associated mRNAs) and a single mRNA may contain in the 3'UTR sequence several signals for miRNA recognition. In this case, antagomiRNAbased therapy should be designed to target multiple miRNAs. MicroRNA targeting and mimicking is further complicated by the facts that, since their discovery and first characterization, the number of miRNA sequences deposited in the miRBase databases is increasing, and research studies on miRNAs in cancer have confirmed the very high complexity of the networks constituted by miRNAs and RNA targets.

One possible approach includes the combination strategies based on the co-administration of anticancer agents, as shown by the observation that $i$ ) the combined administration of different antagomiR molecules induces greater antitumor effects and ii) some anti-miR molecules can sensitize drug-resistant tumor cell lines to drug treatment. In this review, we approached two additional issues: i) the combination of miRNA replacement therapy with drug administration and ii) the combination of antagomiR and miRNA replacement therapy. One of the solid results emerging from different independent studies is the demonstration that miRNA replacement therapy can enhance the antitumor effects of the antitumor drugs.

The second important conclusion of the reviewed studies is that the combination of anti-miRNA and miRNA replacement strategies may lead to excellent results, in terms of antitumor effects. This possible combined strategy is in its infancy and very few studies are available in the literature. Proof-ofprinciple data are presented as examples of possible combined treatments in Fig. 6. Our data indicate that the co-treatment of U251 glioblastoma cells with PNAs targeting miR-221 or miR-222 in the presence of pre-miR-124 transfection leads to a much higher level of apoptosis as opposed to singularly administered reagents. These data further extend the possible combined antitumor treatment based on antitumor drugs and antagomiR-molecules, and present the very novel possibility of combining antagomiR and miRNA replacement therapies.

\section{Acknowledgements}

This study was funded by CIB, by COFIN-2009 and by AIRC (IG 13575: peptide nucleic acids targeting oncomiR and tumorsuppressor miRNAs: cancer diagnosis and therapy). EB is supported by an Umberto Veronesi fellowship. We would like to thank the Horizon-2020 ULTRAPLACAD (ULTRAsensitive PLAsmonic devices for early Cancer Diagnosis) n.633937 project for supporting the research on circulating miRNAs as diagnostic tools.

\section{References}

1. Mazière $\mathrm{P}$ and Enright AJ: Prediction of microRNA targets Drug Discov Today 12: 452-458, 2007.

2. Witkos TM, Koscianska E and Krzyzosiak WJ: Practical aspects of microRNA target prediction. Curr Mol Med 11: 93-109, 2011.

3. Ghelani HS, Rachchh MA and Gokani RH: MicroRNAs as newer therapeutic targets: A big hope from a tiny player. J Pharmacol Pharmacother 3: 217-227, 2012.

4. Krol J, Loedige I and Filipowicz W: The widespread regulation of microRNA biogenesis, function and decay. Nat Rev Genet 11: 597-610, 2010
5. Sun K and Lai EC: Adult-specific functions of animal microRNAs. Nat Rev Genet 14: 535-548, 2013.

6. Chekulaeva M and Filipowicz W: Mechanisms of miRNAmediated post-transcriptional regulation in animal cells. Curr Opin Cell Biol 21: 452-460, 2009.

7. Guo H, Ingolia NT, Weissman JS and Bartel DP: Mammalian microRNAs predominantly act to decrease target mRNA levels. Nature 466: 835-840, 2010.

8. Cammaerts S, Strazisar M, De Rijk P and Del Favero J: Genetic variants in microRNA genes: Impact on microRNA expression, function, and disease. Front Genet 6: 186, 2015.

9. Friedländer MR, Lizano E, Houben AJS, Bezdan D, Báñez-Coronel M, Kudla G, Mateu-Huertas E, Kagerbauer B, González J, Chen KC, et al: Evidence for the biogenesis of more than 1,000 novel human microRNAs. Genome Biol 15: R57, 2014.

10. Cheng WC, Chung IF, Tsai CF, Huang TS, Chen CY, Wang SC, Chang TY, Sun HJ, Chao JY, Cheng CC, et al: YM500v2: a small RNA sequencing (smRNA-seq) database for human cancer miRNome research. Nucleic Acids Res 43: D862-D867, 2015.

11. Londin E, Loher P, Telonis AG, Quann K, Clark P, Jing Y, Hatzimichael E, Kirino Y, Honda S, Lally M, et al: Analysis of 13 cell types reveals evidence for the expression of numerous novel primate- and tissue-specific microRNAs. Proc Natl Acad Sci USA 112: E1106-E1115, 2015.

12. Griffiths-Jones S, Grocock RJ, van Dongen S, Bateman A and Enright AJ: miRBase: microRNA sequences, targets and gene nomenclature. Nucleic Acids Res 34: D140-D144, 2006.

13. Kozomara A and Griffiths-Jones S: miRBase: Annotating high confidence microRNAs using deep sequencing data. Nucleic Acids Res 42: D68-D73, 2014.

14. Taccioli C, Fabbri E, Visone R, Volinia S, Calin GA, Fong LY, Gambari R, Bottoni A, Acunzo M, Hagan J, et al: UCbase and miRfunc: A database of ultraconserved sequences and microRNA function. Nucleic Acids Res 37: D41-D48, 2009.

15. Witwer KW: Data submission and quality in microarray-based microRNA profiling. Clin Chem 59: 392-400, 2013.

16. Xie B, Ding Q, Han H and Wu D: miRCancer: A microRNAcancer association database constructed by text mining on literature. Bioinformatics 29: 638-644, 2013.

17. Lim LP, Lau NC, Garrett-Engele P, Grimson A, Schelter JM, Castle J, Bartel DP, Linsley PS and Johnson JM: Microarray analysis shows that some microRNAs downregulate large numbers of target mRNAs. Nature 433: 769-773, 2005.

18. Peter ME: Targeting of mRNAs by multiple miRNAs: The next step. Oncogene 29: 2161-2164, 2010.

19. Bianchi N, Finotti A, Ferracin M, Lampronti I, Zuccato C, Breveglieri G, Brognara E, Fabbri E, Borgatti M, Negrini M, et al: Increase of microRNA-210, decrease of raptor gene expression and alteration of mammalian target of rapamycin regulated proteins following mithramycin treatment of human erythroid cells. PLoS One 10: e0121567, 2015.

20. Subramanian S and Steer CJ: MicroRNAs as gatekeepers of apoptosis. J Cell Physiol 223: 289-298, 2010.

21. Wang Y and Blelloch R: Cell cycle regulation by MicroRNAs in embryonic stem cells. Cancer Res 69: 4093-4096, 2009.

22. Fabbri E, Borgatti M, Montagner G, Bianchi N, Finotti A Lampronti I, Bezzerri V, Dechecchi MC, Cabrini G and Gambari R: Expression of microRNA-93 and Interleukin-8 during Pseudomonas aeruginosa-mediated induction of proinflammatory responses. Am J Respir Cell Mol Biol 50: 1144-1155, 2014.

23. Faruq O and Vecchione A: microRNA: Diagnostic perspective. Front Med Lausanne 2: 51, 2015.

24. Shalaby T, Fiaschetti G, Baumgartner M and Grotzer MA: Significance and therapeutic value of miRNAs in embryonal neural tumors. Molecules 19: 5821-5862, 2014.

25. Calin GA, Sevignani C, Dumitru CD, Hyslop T, Noch E, Yendamuri S, Shimizu M, Rattan S, Bullrich F, Negrini M, et al: Human microRNA genes are frequently located at fragile sites and genomic regions involved in cancers. Proc Natl Acad Sci USA 101: 2999-3004, 2004.

26. Palmero EI, de Campos SG, Campos M, de Souza NC, Guerreiro ID, Carvalho AL and Marques MM: Mechanisms and role of microRNA deregulation in cancer onset and progression. Genet Mol Biol 34: 363-370, 2011.

27. Weber JA, Baxter DH, Zhang S, Huang DY, Huang KH, Lee MJ, Galas DJ and Wang K: The microRNA spectrum in 12 body fluids. Clin Chem 56: 1733-1741, 2010.

28. Fayyad-Kazan H, Bitar N, Najar M, Lewalle P, Fayyad-Kazan M, Badran R, Hamade E, Daher A, Hussein N, ElDirani R, et al: Circulating miR-150 and miR-342 in plasma are novel potential biomarkers for acute myeloid leukemia. J Transl Med 11: 31, 2013. 
29. Neviani P and Fabbri M: Exosomic microRNAs in the tumor microenvironment. Front Med Lausanne 2: 47, 2015.

30. Köberle V, Kronenberger B, Pleli T, Trojan J, Imelmann E, Peveling-Oberhag J, Welker MW, Elhendawy M, Zeuzem S, Piiper A, et al: Serum microRNA-1 and microRNA-122 are prognostic markers in patients with hepatocellular carcinoma. Eur J Cancer 49: 3442-3449, 2013.

31. He Y, Lin J, Kong D, Huang M, Xu C, Kim TK, Etheridge A, Luo Y, Ding Y and Wang K: Current state of circulating MicroRNAs as cancer biomarkers. Clin Chem 61: 1138-1155, 2015.

32. Westphal $\mathrm{M}$ and Lamszus K: Circulating biomarkers for gliomas. Nat Rev Neurol 11: 556-566, 2015.

33. Yau TO, Wu CW, Dong Y, Tang CM, Ng SS, Chan FK, Sung JJ and $\mathrm{Yu}$ J: microRNA-221 and microRNA-18a identification in stool as potential biomarkers for the non-invasive diagnosis of colorectal carcinoma. Br J Cancer 111: 1765-1771, 2014.

34. Cheng H, Zhang L, Cogdell DE, Zheng H, Schetter AJ, Nykter M, Harris CC, Chen K, Hamilton SR and Zhang W: Circulating plasma MiR-141 is a novel biomarker for metastatic colon cancer and predicts poor prognosis. PLoS One 6: e17745, 2011.

35. Czech MP: MicroRNAs as therapeutic targets. N Engl J Med 354: 1194-1195, 2006

36. Brown BD and Naldini L: Exploiting and antagonizing microRNA regulation for therapeutic and experimental applications. Nat Rev Genet 10: 578-585, 2009.

37. Kota SK and Balasubramanian S: Cancer therapy via modulation of micro RNA levels: A promising future. Drug Discov Today 15 : 733-740, 2010.

38. Small EM and Olson EN: Pervasive roles of microRNAs in cardiovascular biology. Nature 469: 336-342, 2011.

39. Bader AG and Lammers P: The Therapeutic Potential of microRNAs. Discovery Technology, 2011.

40. Rothschild SI: microRNA therapies in cancer. Mol Cell Ther 2: 7, 2014.

41. van Rooij E and Kauppinen S: Development of microRNA therapeutics is coming of age. EMBO Mol Med 6: 851-864, 2014.

42. Orellana EA and Kasinski AL: MicroRNAs in cancer: A historical perspective on the path from discovery to therapy. Cancers (Basel) 7: 1388-1405, 2015.

43. Berindan-Neagoe I, Monroig PC, Pasculli B and Calin GA MicroRNAome genome: A treasure for cancer diagnosis and therapy. CA Cancer J Clin 64: 311-336, 2014.

44. Bernardo BC, Ooi JY, Lin RC and McMullen JR: miRNA therapeutics: A new class of drugs with potential therapeutic applications in the heart. Future Med Chem 7: 1771-1792, 2015.

45. Weiler J, Hunziker J and Hall J: Anti-miRNA oligonucleotides (AMOs): Ammunition to target miRNAs implicated in human disease? Gene Ther 13: 496-502, 2006.

46. Lu Y, Xiao J, Lin H, Bai Y, Luo X, Wang Z and Yang B: A single anti-microRNA antisense oligodeoxyribonucleotide (AMO) targeting multiple microRNAs offers an improved approach for microRNA interference. Nucleic Acids Res 37: e24, 2009.

47. Lennox KA and Behlke MA: Chemical modification and design of anti-miRNA oligonucleotides. Gene Ther 18: 1111-1120, 2011.

48. Obad S, dos Santos CO, Petri A, Heidenblad M, Broom O, Ruse C, Fu C, Lindow M, Stenvang J, Straarup EM, et al: Silencing of microRNA families by seed-targeting tiny LNAs. Nat Genet 43 . 371-378, 2011.

49. Elmén J, Lindow M, Schütz S, Lawrence M, Petri A, Obad S, Lindholm M, Hedtjärn M, Hansen HF, Berger U, et al: LNA-mediated microRNA silencing in non-human primates. Nature 452: 896-899, 2008

50. Stenvang J, Silahtaroglu AN, Lindow M, Elmen J and Kauppinen S: The utility of LNA in microRNA-based cancer diagnostics and therapeutics. Semin Cancer Biol 18: 89-102, 2008

51. Chabot S, Teissié J and Golzio M: Targeted electro-delivery of oligonucleotides for RNA interference: siRNA and antimiR. Adv Drug Deliv Rev 81: 161-168, 2015.

52. Lundin KE, Højland T, Hansen BR, Persson R, Bramsen JB, Kjems J, Koch T, Wengel J and Smith CI: Biological activity and biotechnological aspects of locked nucleic acids. Adv Genet 82 47-107, 2013.

53. Staedel C, Varon C, Nguyen PH, Vialet B, Chambonnier L, Rousseau B, Soubeyran I, Evrard S, Couillaud F and Darfeuille F: Inhibition of gastric tumor cell growth using seed-targeting LNA as specific, long-lasting MicroRNA inhibitors. Mol Ther Nucleic Acids 4: e246, 2015.
54. Avitabile C, Accardo A, Ringhieri P, Morelli G, Saviano M, Montagner G, Fabbri E, Gallerani E, Gambari R and Romanelli A: Incorporation of naked peptide nucleic acids into liposomes leads to fast and efficient delivery. Bioconjug Chem 26: 1533-1541, 2015.

55. Fabbri E, Manicardi A, Tedeschi T, Sforza S, Bianchi N, Brognara E, Finotti A, Breveglieri G, Borgatti M, Corradini R, et al: Modulation of the biological activity of microRNA-210 with peptide nucleic acids (PNAs). ChemMedChem 6: 2192-2202, 2011.

56. Brognara E, Fabbri E, Bazzoli E, Montagner G, Ghimenton C, Eccher A, Cantù C, Manicardi A, Bianchi N, Finotti A, et al: Uptake by human glioma cell lines and biological effects of a peptide-nucleic acids targeting miR-221. J Neurooncol 118: 19-28, 2014.

57. Cheng CJ, Bahal R, Babar IA, Pincus Z, Barrera F, Liu C, Svoronos A, Braddock DT, Glazer PM, Engelman DM, et al: MicroRNA silencing for cancer therapy targeted to the tumour microenvironment. Nature 518: 107-110, 2015.

58. Morris JK, Chomyk A, Song P, Parker N, Deckard S, Trapp BD, Pimplikar SW and Dutta R: Decrease in levels of the evolutionarily conserved microRNA miR-124 affects oligodendrocyte numbers in Zebrafish, Danio rerio. Invert Neurosci 15: 4,2015

59. Conte I, Hadfield KD, Barbato S, Carrella S, Pizzo M, Bhat RS Carissimo A, Karali M, Porter LF, Urquhart J, et al: MiR-204 is responsible for inherited retinal dystrophy associated with ocular coloboma. Proc Natl Acad Sci USA 112: E3236-E3245, 2015.

60. Ristori E, Lopez-Ramirez MA, Narayanan A, Hill-Teran G, Moro A, Calvo CF, Thomas JL and Nicoli S: A Dicer-miR-107 interaction regulates biogenesis of specific miRNAs crucial for neurogenesis. Dev Cell 32: 546-560, 2015.

61. Ebert MS, Neilson JR and Sharp PA: MicroRNA sponges: Competitive inhibitors of small RNAs in mammalian cells. Nat Methods 4: 721-726, 2007.

62. Ebert MS and Sharp PA: MicroRNA sponges: Progress and possibilities. RNA 16: 2043-2050, 2010.

63. Kluiver J, Gibcus JH, Hettinga C, Adema A, Richter MK, Halsema N, Slezak-Prochazka I, Ding Y, Kroesen BJ and van den Berg A: Rapid generation of microRNA sponges for microRNA inhibition. PLoS One 7: e29275, 2012a.

64. Kluiver J, Slezak-Prochazka I, Smigielska-Czepiel K, Halsema N, Kroesen BJ and van den Berg A: Generation of miRNA sponge constructs. Methods 58: 113-117, 2012.

65. Li KC, Chang YH, Yeh CL and Hu YC: Healing of osteoporotic bone defects by baculovirus-engineered bone marrow-derived MSCs expressing MicroRNA sponges. Biomaterials 74: 155-166, 2016.

66. de Melo Maia B, Ling H, Monroig P, Ciccone M, Soares FA, Calin GA and Rocha RM: Design of a miRNA sponge for the miR-17 miRNA family as a therapeutic strategy against vulvar carcinoma. Mol Cell Probes 29: 420-426, 2015.

67. Tay FC, Lim JK, Zhu H, Hin LC and Wang S: Using artificial microRNA sponges to achieve microRNA loss-of-function in cancer cells. Adv Drug Deliv Rev 81: 117-127, 2015.

68. Liu Y, Han Y, Zhang H, Nie L, Jiang Z, Fa P, Gui Y and Cai Z: Synthetic miRNA-mowers targeting miR-183-96-182 cluster or miR-210 inhibit growth and migration and induce apoptosis in bladder cancer cells. PLoS One 7: e52280, 2012.

69. Choi WY, Giraldez AJ and Schier AF: Target protectors reveal dampening and balancing of Nodal agonist and antagonist by miR-430. Science 318: 271-274, 2007.

70. Haraguchi T, Ozaki Y and Iba H: Vectors expressing efficient RNA decoys achieve the long-term suppression of specific microRNA activity in mammalian cells. Nucleic Acids Res 37: e43, 2009.

71. Krol J, Busskamp V, Markiewicz I, Stadler MB, Ribi S, Richter J, Duebel J, Bicker S, Fehling HJ, Schübeler D, et al: Characterizing light-regulated retinal microRNAs reveals rapid turnover as a common property of neuronal microRNAs. Cell 141: 618-631, 2010.

72. Cassidy JJ, Straughan AJ and Carthew RW: Differential masking of natural genetic variation by miR-9a in Drosophila. Genetics 202: 675-687, 2016

73. Wang Z: The principles of MiRNA-masking antisense oligonucleotides technology. Methods Mol Biol 676: 43-49, 2011.

74. Bak RO, Hollensen AK and Mikkelsen JG: Managing microRNAs with vector-encoded decoy-type inhibitors. Mol Ther 21: 1478-1485, 2013 
75. Murakami K and Miyagishi M: Tiny masking locked nucleic acids effectively bind to mRNA and inhibit binding of microRNAs in relation to thermodynamic stability. Biomed Rep 2: 509-512, 2014.

76. Shin KJ, Wall EA, Zavzavadjian JR, Santat LA, Liu J, Hwang JI, Rebres R, Roach T, Seaman W, Simon MI, et al: A single lentiviral vector platform for microRNA-based conditional RNA interference and coordinated transgene expression. Proc Natl Acad Sci USA 103: 13759-13764, 2006.

77. Askou AL, Aagaard L, Kostic C, Arsenijevic Y, Hollensen AK, Bek T, Jensen TG, Mikkelsen JG and Corydon TJ: Multigenic lentiviral vectors for combined and tissue-specific expression of miRNA- and protein-based antiangiogenic factors. Mol Ther Methods Clin Dev 2: 14064, 2015.

78. Winbanks CE, Beyer C, Hagg A, Qian H, Sepulveda PV and Gregorevic P: miR-206 represses hypertrophy of myogenic cells but not muscle fibers via inhibition of HDAC4. PLoS One 8: e73589, 2013

79. Montgomery RL, Yu G, Latimer PA, Stack C, Robinson K, Dalby CM, Kaminski N and van Rooij E: MicroRNA mimicry blocks pulmonary fibrosis. EMBO Mol Med 6: 1347-1356, 2014.

80. Bader AG: miR-34 - a microRNA replacement therapy is headed to the clinic. Front Genet 3: 120, 2012

81. Kwekkeboom RF, Lei Z, Doevendans PA, Musters RJ and Sluijter JP: Targeted delivery of miRNA therapeutics for cardiovascular diseases: Opportunities and challenges. Clin Sci (Lond) 127: 351-365, 2014.

82. Sherr CJ: Principles of tumor suppression. Cell 116: 235-246, 2004

83. Lee YS and Dutta A: The tumor suppressor microRNA let-7 represses the HMGA2 oncogene. Genes Dev 21: 1025-1030, 2007.

84. Mayr C, Hemann MT and Bartel DP: Disrupting the pairing between let-7 and Hmga2 enhances oncogenic transformation. Science 315: 1576-1579, 2007.

85. Park SM, Shell S, Radjabi AR, Schickel R, Feig C, Boyerinas B Dinulescu DM, Lengyel E and Peter ME: Let-7 prevents early cancer progression by suppressing expression of the embryonic gene HMGA2. Cell Cycle 6: 2585-2590, 2007

86. Sampson VB, Rong NH, Han J, Yang Q, Aris V, Soteropoulos P, Petrelli NJ, Dunn SP and Krueger LJ: MicroRNA let-7a downregulates MYC and reverts MYC-induced growth in Burkit lymphoma cells. Cancer Res 67: 9762-9770, 2007.

87. Müller DW and Bosserhoff AK: Integrin beta 3 expression is regulated by let-7a miRNA in malignant melanoma. Oncogene 27: 6698-6706, 2008.

88. Peng Y, Laser J, Shi G, Mittal K, Melamed J, Lee P and Wei JJ: Antiproliferative effects by Let-7 repression of high-mobility group A2 in uterine leiomyoma. Mol Cancer Res 6: 663-673, 2008 .

89. Bader AG, Brown D and Winkler M: The promise of microRNA replacement therapy. Cancer Res 70: 7027-7030, 2010

90. Wiggins JF, Ruffino L, Kelnar K, Omotola M, Patrawala L, Brown D and Bader AG: Development of a lung cancer therapeutic based on the tumor suppressor microRNA-34. Cancer Res 70: 5923-5930, 2010.

91. Ibrahim AF, Weirauch U, Thomas M, Grünweller A Hartmann RK and Aigner A: MicroRNA replacement therapy for miR-145 and miR-33a is efficacious in a model of colon carcinoma. Cancer Res 71: 5214-5224, 2011.

92. Trang P, Wiggins JF, Daige CL, Cho C, Omotola M, Brown D, Weidhaas JB, Bader AG and Slack FJ: Systemic delivery of tumor suppressor microRNA mimics using a neutral lipid emulsion inhibits lung tumors in mice. Mol Ther 19: 1116-1122, 2011.

93. Buechner J, Tømte E, Haug BH, Henriksen JR, Løkke C Flægstad T and Einvik C: Tumour-suppressor microRNAs let-7 and miR-101 target the proto-oncogene MYCN and inhibit cell proliferation in MYCN-amplified neuroblastoma. Br J Cancer 105: 296-303, 2011.

94. Scheibner KA, Teaboldt B, Hauer MC, Chen X, Cherukuri S, Guo Y, Kelley SM, Liu Z, Baer MR, Heimfeld S, et al: MiR-27a functions as a tumor suppressor in acute leukemia by regulating 14-3-30. PLoS One 7: e50895, 2012.

95. Thomas M, Lange-Grünweller K, Weirauch U, Gutsch D, Aigner A, Grünweller A and Hartmann RK: The proto-oncogene Pim-1 is a target of miR-33a. Oncogene 31: 918-928, 2012.

96. Endo H, Muramatsu T, Furuta M, Uzawa N, Pimkhaokham A Amagasa T, Inazawa $\mathbf{J}$ and Kozaki K: Potential of tumorsuppressive miR-596 targeting LGALS3BP as a therapeutic agent in oral cancer. Carcinogenesis 34: 560-569, 2013.
97. Wu Y, Crawford M, Mao Y, Lee RJ, Davis IC, Elton TS, Lee LJ and Nana-Sinkam SP: Therapeutic delivery of microRNA-29b by cationic lipoplexes for lung cancer. Mol Ther Nucleic Acids 2 : e84, 2013.

98. Huang X, Schwind S, Yu B, Santhanam R, Wang H, Hoellerbauer P, Mims A, Klisovic R, Walker AR, Chan KK, et al Targeted delivery of microRNA-29b by transferrin-conjugated anionic lipopolyplex nanoparticles: A novel therapeutic strategy in acute myeloid leukemia. Clin Cancer Res 19: 2355-2367, 2013

99. Liang Z, Ahn J, Guo D, Votaw JR and Shim H: MicroRNA-302 replacement therapy sensitizes breast cancer cells to ionizing radiation. Pharm Res 30: 1008-1016, 2013.

100. Møller HG, Rasmussen AP, Andersen HH, Johnsen KB Henriksen M and Duroux M: A systematic review of microRNA in glioblastoma multiforme: Micro-modulators in the mesenchymal mode of migration and invasion. Mol Neurobiol 47: 131-144, 2013.

101. Hershkovitz-Rokah O, Modai S, Pasmanik-Chor M, Toren A Shomron N, Raanani P, Shpilberg O and Granot G: Restoration of miR-424 suppresses BCR-ABL activity and sensitizes CML cells to imatinib treatment. Cancer Lett 360: 245-256, 2015.

102. Lee YM, Lee JY, Ho CC, Hong QS, Yu SL, Tzeng CR, Yang PC and Chen HW: miRNA-34b as a tumor suppressor in estrogendependent growth of breast cancer cells. Breast Cancer Res 13 R116, 2011.

103. Huang P, Ye B, Yang Y, Shi J and Zhao H: MicroRNA-181 functions as a tumor suppressor in non-small cell lung cancer (NSCLC) by targeting Bcl-2. Tumour Biol 36: 3381-3387, 2015

104. Su R, Lin HS, Zhang XH, Yin XL, Ning HM, Liu B, Zhai PF, Gong JN, Shen C, Song L, et al: MiR-181 family: Regulators of myeloid differentiation and acute myeloid leukemia as well as potential therapeutic targets. Oncogene 34: 3226-3239, 2015.

105. Bachetti T, Di Zanni E, Ravazzolo R and Ceccherini I: miR-204 mediates post-transcriptional down-regulation of $\mathrm{PHOX} 2 \mathrm{~B}$ gene expression in neuroblastoma cells. Biochim Biophys Acta 1849: $1057-1065,2015$

106. Fernandez S, Risolino M, Mandia N, Talotta F, Soini Y, Incoronato M, Condorelli G, Banfi S and Verde P: miR-340 inhibits tumor cell proliferation and induces apoptosis by targeting multiple negative regulators of p27 in non-small cel lung cancer. Oncogene 34: 3240-3250, 2015.

107.Liu G, Liu Y, Yang Z, Wang J, Li D and Zhang X: Tumor suppressor microRNA-18a regulates tumor proliferation and invasion by targeting TBPL1 in colorectal cancer cells. Mol Med Rep 12: 7643-7648, 2015.

108. Xishan Z, Ziying L, Jing D and Gang L: MicroRNA-320a acts as a tumor suppressor by targeting BCR/ABL oncogene in chronic myeloid leukemia. Sci Rep 5: 12460, 2015

109.Zhao Z, Ma X, Sung D, Li M, Kosti A, Lin G, Chen Y, Pertsemlidis A, Hsiao TH and Du L: microRNA-449a functions as a tumor suppressor in neuroblastoma through inducing cell differentiation and cell cycle arrest. RNA Biol 12: 538-554, 2015 .

110. Kalinowski FC, Brown RA, Ganda C, Giles KM, Epis MR, Horsham $\mathrm{J}$ and Leedman PJ: microRNA-7: A tumor suppressor miRNA with therapeutic potential. Int J Biochem Cell Biol 54 312-317, 2014

111. Gu DN, Huang Q and Tian L: The molecular mechanisms and therapeutic potential of microRNA-7 in cancer. Expert Opin Ther Targets 19: 415-426, 2015.

112. Nohata N,Hanazawa T, Enokida H and Seki N: microRNA-1/133a and microRNA-206/133b clusters: Dysregulation and functional roles in human cancers. Oncotarget 3: 9-21, 2012.

113. Hudson RS, Yi M, Esposito D, Watkins SK, Hurwitz AA, Yfantis HG, Lee DH, Borin JF, Naslund MJ, Alexander RB, et al: MicroRNA-1 is a candidate tumor suppressor and prognostic marker in human prostate cancer. Nucleic Acids Res 40: 3689-3703, 2012.

114. Chang YS, Chen WY, Yin JJ, Sheppard-Tillman H, Huang J and Liu YN: EGF receptor pomotes prostate cancer bone metastasis by downregulating miR-1 and activating TWIST1. Cancer Res 75: 3077-3086, 2015

115. Zhang H, Cai K, Wang J, Wang X, Cheng K, Shi F, Jiang L, Zhang Y and Dou J: MiR-7, inhibited indirectly by lincRNA HOTAIR, directly inhibits SETDB1 and reverses the EMT of breast cancer stem cells by downregulating the STAT3 pathway. Stem Cells 32: 2858-2868, 2014a

116. Okuda H, Xing F, Pandey PR, Sharma S, Watabe M, Pai SK, Mo YY, Iiizumi-Gairani M, Hirota S, Liu Y, et al: miR-7 suppresses brain metastasis of breast cancer stem-like cells by modulating KLF4. Cancer Res 73: 1434-1444, 2013. 
117.Zhou X, Hu Y, Dai L, Wang Y, Zhou J, Wang W, Di W and Qiu L: MicroRNA-7 inhibits tumor metastasis and reverses epithelial-mesenchymal transition through AKT/ERK1/2 inactivation by targeting EGFR in epithelial ovarian cancer. PLoS One 9: e96718, 2014.

118. Dangi-Garimella S, Yun J, Eves EM, Newman M, Erkeland SJ, Hammond SM, Minn AJ and Rosner MR: Raf kinase inhibitory protein suppresses a metastasis signalling cascade involving LIN28 and let-7. EMBO J 28: 347-358, 2009.

119. Takamizawa J, Konishi H, Yanagisawa K, Tomida S, Osada $H$ Endoh H, Harano T, Yatabe Y, Nagino M, Nimura Y, et al: Reduced expression of the let-7 microRNAs in human lung cancers in association with shortened postoperative survival. Cancer Res 64: 3753-3756, 2004.

120. Shi XB, Tepper CG and deVere White RW: Cancerous miRNAs and their regulation. Cell Cycle 7: 1529-1538, 2008

121. Johnson SM, Grosshans H, Shingara J, Byrom M, Jarvis R, Cheng A, Labourier E, Reinert KL, Brown D and Slack FJ: RAS is regulated by the let-7 microRNA family. Cell 120: 635-647, 2005 .

122.Zheng L, Qi T, Yang D, Qi M, Li D, Xiang X, Huang K and Tong Q: microRNA-9 suppresses the proliferation, invasion and metastasis of gastric cancer cells through targeting cyclin D1 and Ets1. PLoS One 8: e55719, 2013.

123. Aqeilan RI, Calin GA and Croce CM: miR-15a and miR-16-1 in cancer: Discovery, function and future perspectives. Cell Death Differ 17: 215-220, 2010

124. Calin GA, Dumitru CD, Shimizu M, Bichi R, Zupo S, Noch E, Aldler H, Rattan S, Keating M, Rai K, et al: Frequent deletions and down-regulation of micro-RNA genes miR 15 and miR 16 at $13 q 14$ in chronic lymphocytic leukemia. Proc Natl Acad Sci USA 99: 15524-15529, 2002.

125.Pekarsky Y and Croce CM: Role of miR-15/16 in CLL. Cell Death Differ 22: 6-11, 2015.

126. Bonci D, Coppola V, Musumeci M, Addario A, Giuffrida R Memeo L, D'Urso L, Pagliuca A, Biffoni M, Labbaye C, et al: The miR-15a-miR-16-1 cluster controls prostate cancer by targeting multiple oncogenic activities. Nat Med 14: 1271-1277, 2008

127.Kang W, Tong JH, Lung RW, Dong Y, Zhao J, Liang Q, Zhang L, Pan Y, Yang W, Pang JC, et al: Targeting of YAP1 by microRNA-15a and microRNA-16-1 exerts tumor suppressor function in gastric adenocarcinoma. Mol Cancer 14: 52, 2015

128. Chen F, Chen L, He H, Huang W, Zhang R, Li P, et al: Up-regulation of microRNA-16 in glioblastoma inhibits the function of endothelial cells and tumor angiogenesis by targeting Bmi-1. Anticancer Agents Med Chem, 2015.

129. Humphreys KJ, McKinnon RA and Michael MZ: miR-18a inhibits CDC42 and plays a tumour suppressor role in colorectal cancer cells. PLoS One 9: e112288, 2014.

130.Zoni E, van der Horst G, van de Merbel AF, Chen L, Rane JK, Pelger RC, Collins AT, Visakorpi T, Snaar-Jagalska BE, Maitland NJ, et al: miR-25 modulates invasiveness and dissemination of human prostate cancer cells via regulation of $\alpha \mathrm{v}$ - and a6 integrin expression. Cancer Res 75: 2326-2336, 2015.

131. Sengupta S, den Boon JA, Chen IH, Newton MA, Stanhope SA, Cheng YJ, Chen CJ, Hildesheim A, Sugden B and Ahlquist P: MicroRNA 29c is down-regulated in nasopharyngeal carcinomas, up-regulating mRNAs encoding extracellular matrix proteins. Proc Natl Acad Sci USA 105: 5874-5878, 2008.

132. Ugalde AP, Ramsay AJ, de la Rosa J, Varela I, Mariño G, Cadiñanos J, Lu J, Freije JM and López-Otín C: Aging and chronic DNA damage response activate a regulatory pathway involving miR-29 and p53. EMBO J 30: 2219-2232, 2011.

133. Garzon R, Heaphy CE, Havelange V, Fabbri M, Volinia S, Tsao T, Zanesi N, Kornblau SM, Marcucci G, Calin GA, et al: MicroRNA 29b functions in acute myeloid leukemia. Blood 114: 5331-5341, 2009a.

134. Garzon R, Liu S, Fabbri M, Liu Z, Heaphy CE, Callegari E, Schwind S, Pang J, Yu J, Muthusamy N, et al: MicroRNA-29b induces global DNA hypomethylation and tumor suppressor gene reexpression in acute myeloid leukemia by targeting directly DNMT3A and 3B and indirectly DNMT1. Blood 113. 6411-6418, 2009b.

135. Kapinas K, Kessler CB and Delany AM: miR-29 suppression of osteonectin in osteoblasts: Regulation during differentiation and by canonical Wnt signaling. J Cell Biochem 108: 216-224, 2009.

136. Mott JL, Kobayashi S, Bronk SF and Gores GJ: miR-29 regulates Mcl-1 protein expression and apoptosis. Oncogene 26: 6133-6140, 2007.
137. Fabbri M, Garzon R, Cimmino A, Liu Z, Zanesi N, Callegari E, Liu S, Alder H, Costinean S, Fernandez-Cymering C, et al: MicroRNA-29 family reverts aberrant methylation in lung cancer by targeting DNA methyltransferases $3 \mathrm{~A}$ and $3 \mathrm{~B}$. Proc Natl Acad Sci USA 104: 15805-15810, 2007.

138. Xiong Y, Fang JH, Yun JP, Yang J, Zhang Y, Jia WH and Zhuang SM: Effects of microRNA-29 on apoptosis, tumorigenicity, and prognosis of hepatocellular carcinoma. Hepatology 51: 836-845, 2010.

139. Filkowski JN, Ilnytskyy Y, Tamminga J, Koturbash I, Golubov A, Bagnyukova T, Pogribny IP and Kovalchuk O: Hypomethylation and genome instability in the germline of exposed parents and their progeny is associated with altered miRNA expression. Carcinogenesis 31: 1110-1115, 2010 .

140. Wang Y, Zhang X, Li H, Yu J and Ren X: The role of miRNA-29 family in cancer. Eur J Cell Biol 92: 123-128, 2013.

141. Hu W, Dooley J, Chung SS, Chandramohan D, Cimmino L, Mukherjee S, Mason CE, de Strooper B, Liston A and Park CY: miR-29a maintains mouse hematopoietic stem cell self-renewal by regulating Dnmt3a. Blood 125: 2206-2216, 2015

142. Li L and Wang B: Overexpression of microRNA-30b improves adenovirus-mediated p53 cancer gene therapy for laryngeal carcinoma. Int J Mol Sci 15: 19729-19740, 2014.

143. Hou C, Sun B, Jiang Y, Zheng J, Yang N, Ji C, Liang Z, Shi J, Zhang R, Liu Y, et al: MicroRNA-31 inhibits lung adenocarcinoma stem-like cells via down-regulation of MET-PI3K-Akt signaling pathway. Anticancer Agents Med Chem 16: 501-518, 2016.

144. Valastyan S, Reinhardt F, Benaich N, Calogrias D, Szász AM, Wang ZC, Brock JE, Richardson AL and Weinberg RA: A pleiotropically acting microRNA, miR-31, inhibits breast cancer metastasis. Cell 137: 1032-1046, 2009.

145. Sossey-Alaoui K, Downs-Kelly E, Das M, Izem L, Tubbs R and Plow EF: WAVE3, an actin remodeling protein, is regulated by the metastasis suppressor microRNA, miR-31, during the invasion-metastasis cascade. Int J Cancer 129: 1331-1343, 2011.

146. Lin Y, Liu AY, Fan C, Zheng H, Li Y, Zhang C, Wu S, Yu D, Huang Z, Liu F, et al: MicroRNA-33b inhibits breast cancer metastasis by targeting HMGA2, SALL4 and Twist1. Sci Rep 5: 9995, 2015.

147. Xu N,LiZ, Yu Z, Yan F, Liu Y, Lu X and Yang W: MicroRNA-33b suppresses migration and invasion by targeting c-Myc in osteosarcoma cells. PLoS One 9: e115300, 2014.

148. He L, He X, Lim LP, de Stanchina E, Xuan Z, Liang Y, Xue W, Zender L, Magnus J, Ridzon D, et al: A microRNA component of the p53 tumour suppressor network. Nature 447: 1130-1134, 2007.

149. Bommer GT, Gerin I, Feng Y, Kaczorowski AJ, Kuick R, Love RE, Zhai Y, Giordano TJ, Qin ZS, Moore BB, et al: p53-mediated activation of miRNA34 candidate tumorsuppressor genes. Curr Biol 17: 1298-1307, 2007.

150. Fujita Y, Kojima K, Hamada N, Ohhashi R, Akao Y, Nozawa Y, Deguchi $\mathrm{T}$ and Ito $\mathrm{M}$ : Effects of miR-34a on cell growth and chemoresistance in prostate cancer PC 3 cells. Biochem Biophys Res Commun 377: 114-119, 2008.

151.Leucci E, Cocco M, Onnis A, De Falco G, van Cleef P, Bellan C, van Rijk A, Nyagol J, Byakika B, Lazzi S, et al: MYC translocation-negative classical Burkitt lymphoma cases: An alternative pathogenetic mechanism involving miRNA deregulation. J Pathol 216: 440-450, 2008.

152. Saito Y, Nakaoka T and Saito H: microRNA-34a as a therapeutic agent against human cancer. J Clin Med 4: 1951-1959, 2015.

153. Wei JS, Song YK, Durinck S, Chen QR, Cheuk AT, Tsang P, Zhang Q, Thiele CJ, Slack A, Shohet J, et al: The MYCN oncogene is a direct target of miR-34a. Oncogene 27: 5204-5213, 2008.

154. Yamakuchi M, Ferlito M and Lowenstein CJ: miR-34a repression of SIRT1 regulates apoptosis. Proc Natl Acad Sci USA 105: 13421-13426, 2008.

155. Lodygin D, Tarasov V, Epanchintsev A, Berking C, Knyazeva T, Körner H, Knyazev P, Diebold J and Hermeking H: Inactivation of miR-34a by aberrant $\mathrm{CpG}$ methylation in multiple types of cancer. Cell Cycle 7: 2591-2600, 2008.

156. Yang S, Li Y, Gao J, Zhang T, Li S, Luo A, Chen H, Ding F, Wang X and Liu Z: MicroRNA-34 suppresses breast cancer invasion and metastasis by directly targeting Fra-1. Oncogene 32 : 4294-4303, 2013.

157. Yang P, Li QJ, Feng Y, Zhang Y, Markowitz GJ, Ning S, Deng Y, Zhao J, Jiang S, Yuan Y, et al: TGF- $\beta$-miR-34a-CCL22 signaling-induced Treg cell recruitment promotes venous metastases of HBV-positive hepatocellular carcinoma. Cancer Cell 22: 291-303, 2012 
158.Liu C, Kelnar K, Liu B, Chen X, Calhoun-Davis T, Li H, Patrawala L, Yan H, Jeter C, Honorio S, et al: The microRNA miR-34a inhibits prostate cancer stem cells and metastasis by directly repressing CD44. Nat Med 17: 211-215, 2011.

159. Krzeszinski JY, Wei W, Huynh H, Jin Z, Wang X, Chang TC Xie XJ, He L, Mangala LS, Lopez-Berestein G, et al: miR-34a blocks osteoporosis and bone metastasis by inhibiting osteoclastogenesis and Tgif2. Nature 512: 431-435, 2014.

160. Wang LG, Ni Y,Su BH,MuXR, Shen HC and Du JJ:MicroRNA-34b functions as a tumor suppressor and acts as a nodal point in the feedback loop with Met. Int J Oncol 42: 957-962, 2013.

161. Yu Z, Kim J, He L, Creighton CJ, Gunaratne PH, Hawkins SM and Matzuk MM: Functional analysis of miR-34c as a putative tumor suppressor in high-grade serous ovarian cancer. Biol Reprod 91: $113,2014$.

162. Liu XY, Liu ZJ, He H, Zhang C and Wang YL: MicroRNA-101-3p suppresses cell proliferation, invasion and enhances chemotherapeutic sensitivity in salivary gland adenoid cystic carcinoma by targeting Pim-1. Am J Cancer Res 5: 3015-3029, 2015.

163. Tsai WC, Hsu SD, Hsu CS, Lai TC, Chen SJ, Shen R, Huang Y, Chen HC, Lee CH, Tsai TF, et al: MicroRNA-122 plays a critical role in liver homeostasis and hepatocarcinogenesis. J Clin Invest 122: 2884-2897, 2012

164. Taniguchi K, Sugito N, Kumazaki M, Shinohara H, Yamada N, Nakagawa Y, Ito Y, Otsuki Y, Uno B, Uchiyama K, et al: MicroRNA-124 inhibits cancer cell growth through PTB1/PKM1/ PKM2 feedback cascade in colorectal cancer. Cancer Lett 363 : $17-27,2015$.

165.Huang TC, Chang HY, Chen CY, Wu PY, Lee H, Liao YF, Hsu WM, Huang HC and Juan HF: Silencing of miR-124 induces neuroblastoma SK-N-SH cell differentiation, cell cycle arrest and apoptosis through promoting AHR. FEBS Lett 585 3582-3586, 2011.

166. Kato T, Enomoto A, Watanabe T, Haga H, Ishida S, Kondo Y, Furukawa K, Urano T, Mii S, Weng L, et al: TRIM27/MRTF-Bdependent integrin $\beta 1$ expression defines leading cells in cancer cell collectives. Cell Rep 7: 1156-1167, 2014.

167.Zheng F, Liao YJ, Cai MY, Liu YH, Liu TH, Chen SP, Bian XW, Guan XY, Lin MC, Zeng YX, et al: The putative tumour suppressor microRNA-124 modulates hepatocellular carcinoma cell aggressiveness by repressing ROCK 2 and EZH2. Gut 61 : 278-289, 2012

168. Wang X, Wu Q, Xu B, Wang P, Fan W, Cai Y, Gu X and Meng F: miR-124 exerts tumor suppressive functions on the cell proliferation, motility and angiogenesis of bladder cancer by fine-tuning UHRF1. FEBS J 282: 4376-4388, 2015.

169.Zhang C, Hu Y, Wan J and He H: MicroRNA-124 suppresses the migration and invasion of osteosarcoma cells via targeting ROR2-mediated non-canonical Wnt signaling. Oncol Rep 34 2195-2201, 2015.

170.Sun Y, Ai X, Shen S and Lu S: NF-кB-mediated miR-124 suppresses metastasis of non-small-cell lung cancer by targeting MYO10. Oncotarget 6: 8244-8254, 2015a.

171. Sun Y, Luo ZM, Guo XM, Su DF and Liu X: An updated role of microRNA-124 in central nervous system disorders: A review. Front Cell Neurosci 9: 193, 2015b.

172. Chen Z, Liu S, Tian L, Wu M, Ai F, Tang W, Zhao L, Ding J, Zhang L and Tang A: miR-124 and miR-506 inhibit colorectal cancer progression by targeting DNMT3B and DNMT1. Oncotarget 6: 38139-38150, 2015.

173.Zhang Y, Li H, Han J and Zhang Y: Down-regulation of microRNA-124 is correlated with tumor metastasis and poor prognosis in patients with lung cancer. Int J Clin Exp Pathol 8: 1967-1972, 2015.

174. Cowden Dahl KD, Dahl R, Kruichak JN, Hudson LG: The epidermal growth factor receptor responsive miR-125a represses mesenchymal morphology in ovarian cancer cells. Neoplasia 11 $1208-1215,2009$.

175. Fan Z, Cui H, Xu X, Lin Z, Zhang X, Kang L, Han B, Meng J, Yan Z, Yan X, et al: MiR-125a suppresses tumor growth, invasion and metastasis in cervical cancer by targeting STAT3. Oncotarget 6: 25266-25280, 2015.

176. Sun Y, Bai Y, Zhang F, Wang Y, Guo Y and Guo L: miR-126 inhibits non-small cell lung cancer cells proliferation by targeting EGFL7. Biochem Biophys Res Commun 391: 1483-1489, 2010

177.Xiong Y, Kotian S, Zeiger MA, Zhang L and Kebebew E: miR-126-3p inhibits thyroid cancer cell growth and metastasis, and is associated with aggressive thyroid cancer. PLoS One 10: e0130496, 2015
178. Wang CZ, Yuan P and Li Y: MiR-126 regulated breast cancer cell invasion by targeting ADAM9. Int J Clin Exp Pathol 8: 6547-6553, 2015

179. Wen Q, Zhao J, Bai L, Wang T, Zhang H and Ma Q: miR-126 inhibits papillary thyroid carcinoma growth by targeting LRP6. Oncol Rep 34: 2202-2210, 2015.

180. Jiang L, He A, Zhang Q and Tao C: miR-126 inhibits cell growth, invasion, and migration of osteosarcoma cells by downregulating ADAM-9. Tumour Biol 35: 12645-12654, 2014.

181. Du C, Lv Z, Cao L, Ding C, Gyabaah OA, Xie H, Zhou L, Wu J and Zheng S: MiR-126-3p suppresses tumor metastasis and angiogenesis of hepatocellular carcinoma by targeting LRP6 and PIK3R2. J Transl Med 12: 259, 2014

182. Zhang Y, Wang X, Xu B, Wang B, Wang Z, Liang Y, Zhou J, $\mathrm{Hu} \mathrm{J}$ and Jiang B: Epigenetic silencing of miR-126 contributes to tumor invasion and angiogenesis in colorectal cancer. Oncol Rep 30: 1976-1984, 2013

183. Png KJ, Halberg N, Yoshida M and Tavazoie SF: A microRNA regulon that mediates endothelial recruitment and metastasis by cancer cells. Nature 481: 190-194, 2011

184. Shi ZM, Wang J, Yan Z, You YP, Li CY, Qian X, Yin Y, Zhao P, Wang YY, Wang XF, et al: MiR-128 inhibits tumor growth and angiogenesis by targeting p70S6K1. PLoS One 7: e32709, 2012.

185. Wuchty S, Arjona D, Li A, Kotliarov Y, Walling J, Ahn S, Zhang A, Maric D, Anolik R, Zenklusen JC, et al: Prediction of associations between microRNAs and gene expression in glioma biology. PLoS One 6: e14681, 2011.

186. Zhang Y, Chao T, Li R, Liu W, Chen Y, Yan X, Gong Y, Yin B, Liu W, Qiang B, et al: MicroRNA-128 inhibits glioma cells proliferation by targeting transcription factor E2F3a. J Mol Med Berl 87: 43-51, 2009.

187. Huang CY, Huang XP, Zhu JY, Chen ZG, Li XJ, Zhang XH, Huang S, He JB, Lian F, Zhao YN, et al: miR-128-3p suppresses hepatocellular carcinoma proliferation by regulating PIK3R and is correlated with the prognosis of HCC patients. Oncol Rep 33: 2889-2898, 2015.

188. Kano M, Seki N, Kikkawa N, Fujimura L, Hoshino I, Akutsu Y, Chiyomaru T, Enokida H, Nakagawa $M$ and Matsubara $\mathrm{H}$ : miR-145, miR-133a and miR-133b: Tumor-suppressive miRNAs target FSCN1 in esophageal squamous cell carcinoma. Int J Cancer 127: 2804-2814, 2010 .

189. Kroiss A, Vincent S, Decaussin-Petrucci M, Meugnier E, Viallet J, Ruffion A, Chalmel F, Samarut J and Allioli N: Androgen-regulated microRNA-135a decreases prostate cancer cell migration and invasion through downregulating ROCK1 and ROCK2. Oncogene 34: 2846-2855, 2015.

190. Liang L, Li X, Zhang X, Lv Z, He G, Zhao W, Ren X, Li Y, Bian X, Liao W, et al: MicroRNA-137, an HMGA1 target, suppresses colorectal cancer cell invasion and metastasis in mice by directly targeting FMNL2. Gastroenterology 144: 624-635.e4, 2013.

191.Xia H, Sun S, Wang B, Wang T, Liang C, Li G, Huang C, Qi D and Chu X: miR-143 inhibits NSCLC cell growth and metastasis by targeting Limk1. Int J Mol Sci 15: 11973-11983, 2014.

192. Gao P, Xing AY, Zhou GY, Zhang TG, Zhang JP, Gao C, Li H and Shi DB: The molecular mechanism of microRNA-145 to suppress invasion-metastasis cascade in gastric cancer. Oncogene 32: 491-501, 2013.

193.Zhang H, Pu J, Qi T, Qi M, Yang C, Li S, Huang K, Zheng L and Tong Q: MicroRNA-145 inhibits the growth, invasion, metastasis and angiogenesis of neuroblastoma cells through targeting hypoxia-inducible factor 2 alpha. Oncogene 33: 387-397, 2014.

194. Bhaumik D, Scott GK, Schokrpur S, Patil CK, Campisi J and Benz CC: Expression of microRNA-146 suppresses NF-kappaB activity with reduction of metastatic potential in breast cancer cells. Oncogene 27: 5643-5647, 2008

195. Lin SL, Chiang A, Chang D and Ying SY: Loss of miR-146a function in hormone-refractory prostate cancer. RNA 14: 417-424, 2008 .

196.Zhang JP, Zeng C, Xu L, Gong J, Fang JH and Zhuang SM: MicroRNA-148a suppresses the epithelial-mesenchymal transition and metastasis of hepatoma cells by targeting Met/Snail signaling. Oncogene 33: 4069-4076, 2014.

197. Cimino D, De Pittà C, Orso F, Zampini M, Casara S, Penna E, Quaglino E, Forni M, Damasco C, Pinatel E, et al: miR148b is a major coordinator of breast cancer progression in a relapseassociated microRNA signature by targeting ITGA5, ROCK1, PIK3CA, NRAS, and CSF1. FASEB J 27: 1223-1235, 2013

198. Bischoff A, Huck B, Keller B, Strotbek M, Schmid S, Boerries M, Busch H, Müller D and Olayioye MA: miR149 functions as a tumor suppressor by controlling breast epithelial cell migration and invasion. Cancer Res 74: 5256-5265, 2014 
199. Visone R, Veronese A, Rassenti LZ, Balatti V, Pearl DK, Acunzo M, Volinia S, Taccioli C, Kipps TJ and Croce CM: miR-181b is a biomarker of disease progression in chronic lymphocytic leukemia. Blood 118: 3072-3079, 2011.

200. Kouri FM, Hurley LA, Daniel WL, Day ES, Hua Y, Hao L, Peng CY, Merkel TJ, Queisser MA, Ritner C, et al: miR-182 integrates apoptosis, growth, and differentiation programs in glioblastoma. Genes Dev 29: 732-745, 2015.

201.Leivonen SK, Rokka A, Ostling P, Kohonen P, Corthals GL, Kallioniemi O and Perälä M: Identification of miR-193b targets in breast cancer cells and systems biological analysis of their functional impact. Mol Cell Proteomics 10: M110.005322, 2011.

202. Yang H, Liu P, Zhang J, Peng X, Lu Z, Yu S, Meng Y, Tong WM and Chen J: Long noncoding RNA MIR31HG exhibits oncogenic property in pancreatic ductal adenocarcinoma and is negatively regulated by miR-193b. Oncogene: Nov 9, 2015 (Epub ahead of print).

203. Tan S,Li R, Ding K, Lobie PE and Zhu T: miR-198 inhibits migration and invasion of hepatocellular carcinoma cells by targeting the HGF/c-MET pathway. FEBS Lett 585: 2229-2234, 2011

204. Bao W, Wang HH, Tian FJ, He XY, Qiu MT, Wang JY, Zhang HJ, Wang LH and Wan XP: A TrkB-STAT3-miR-204-5p regulatory circuitry controls proliferation and invasion of endometrial carcinoma cells. Mol Cancer 12: 155, 2013.

205.Xia Z, Liu F, Zhang J and Liu L: Decreased expression of MiRNA-204-5p contributes to glioma progression and promotes glioma cell growth, migration and invasion. PLoS One 10: e0132399, 2015.

206. Gandellini P, Folini M, Longoni N, Pennati M, Binda M, Colecchia M, Salvioni R, Supino R, Moretti R, Limonta P, et al: miR-205 exerts tumor-suppressive functions in human prostate through down-regulation of protein kinase Cepsilon. Cancer Res 69: 2287-2295, 2009.

207. Chen QY, Jiao DM, Yan L, Wu YQ, Hu HZ, Song J, Yan J, Wu LJ, Xu LQ and Shi JG: Comprehensive gene and microRNA expression profiling reveals miR-206 inhibits MET in lung cancer metastasis. Mol Biosyst 11: 2290-2302, 2015.

208. Chen DL, Wang ZQ, Zeng ZL, Wu WJ, Zhang DS, Luo HY, Wang F, Qiu MZ, Wang DS, Ren C, et al: Identification of microRNA-214 as a negative regulator of colorectal cancer liver metastasis by way of regulation of fibroblast growth factor receptor 1 expression. Hepatology 60: 598-609, 2014

209. Tie J, Pan Y, Zhao L, Wu K, Liu J, Sun S, Guo X, Wang B, Gang Y,Zhang Y, et al: MiR-218 inhibits invasion and metastasis of gastric cancer by targeting the Robol receptor. PLoS Genet 6: e1000879, 2010

210. Wei JJ, Wu X, Peng Y, Shi G, Basturk O, Yang X, Daniels G, Osman I, Ouyang J, Hernando E, et al: Regulation of HMGA1 expression by microRNA-296 affects prostate cancer growth and invasion. Clin Cancer Res 17: 1297-1305, 2011

211. Wang L, Yao J, Shi X, Hu L, Li Z, Song T and Huang C: MicroRNA-302b suppresses cell proliferation by targeting EGFR in human hepatocellular carcinoma SMMC-7721 cells. BMC Cancer 13: 448, 2013.

212. Tavazoie SF, Alarcón C, Oskarsson T, Padua D, Wang Q, Bos PD, Gerald WL and Massagué J: Endogenous human microRNAs that suppress breast cancer metastasis. Nature 451: 147-152, 2008.

213.Hurst DR, Edmonds MD and Welch DR: Metastamir: The field of metastasis-regulatory microRNA is spreading. Cancer Res 69: 7495-7498, 2009

214. Li KK, Pang JC, Lau KM, Zhou L, Mao Y, Wang Y, Poon WS and Ng HK: MiR-383 is downregulated in medulloblastoma and targets peroxiredoxin 3 (PRDX3). Brain Pathol 23: 413-425, 2013.

215. Bou Kheir T, Futoma-Kazmierczak E, Jacobsen A, Krogh A, Bardram L, Hother C, Grønbæk K, Federspiel B, Lund AH and Friis-Hansen L: miR-449 inhibits cell proliferation and is down-regulated in gastric cancer. Mol Cancer 10: 29, 2011.

216.Luo W, Huang B, Li Z, Li H, Sun L, Zhang Q, Qiu X and Wang E: MicroRNA-449a is downregulated in non-small cell lung cancer and inhibits migration and invasion by targeting c-Met. PLoS One 8: e64759, 2013.

217. Okamoto K, Ishiguro T, Midorikawa Y, Ohata H, Izumiya M, Tsuchiya N, Sato A, Sakai H and Nakagama H: miR-493 induction during carcinogenesis blocks metastatic settlement of colon cancer cells in liver. EMBO J 31: 1752-1763, 2012.

218. Gu Y, Cheng Y, Song Y, Zhang Z, Deng M, Wang C, Zheng G and He Z: MicroRNA-493 suppresses tumor growth, invasion and metastasis of lung cancer by regulating E2F1. PLoS One 9: e102602, 2014.
219. Sakai H1, Sato A, Aihara Y, Ikarashi Y, Midorikawa Y, Kracht M, Nakagama $\mathrm{H}$ and Okamoto K: MKK7 mediates miR-493-dependent suppression of liver metastasis of colon cancer cells. Cancer Sci 105: 425-430, 2014.

220. Kikkawa N, Kinoshita T, Nohata N, Hanazawa T, Yamamoto N, Fukumoto I, Chiyomaru T, Enokida H, Nakagawa M, Okamoto Y, et al: microRNA-504 inhibits cancer cell proliferation via targeting CDK6 in hypopharyngeal squamous cell carcinoma. Int J Oncol 44: 2085-2092, 2014.

221. Keklikoglou I, Koerner C, Schmidt C, Zhang JD, Heckmann D, Shavinskaya A, Allgayer H, Gückel B, Fehm T, Schneeweiss A, et al: MicroRNA-520/373 family functions as a tumor suppressor in estrogen receptor negative breast cancer by targeting NF- $\kappa \mathrm{B}$ and TGF- $\beta$ signaling pathways. Oncogene 31: 4150-4163, 2012.

222. Song B, Ji W, Guo S, Liu A, Jing W, Shao C, Li G and Jin G: miR-545 inhibited pancreatic ductal adenocarcinoma growth by targeting RIG-I. FEBS Lett 588: 4375-4381, 2014.

223. Bowen D, Zhe W, Xin Z, Shipeng F, Guoxin W, Jianxing H and Zhang B: MicroRNA-545 suppresses cell proliferation by targeting cyclin D1 and CDK4 in lung cancer cells. PLoS 9: 88022, 2014

224. Calin GA, Ferracin M, Cimmino A, Di Leva G, Shimizu M, Wojcik SE, Iorio MV, Visone R, Sever NI, Fabbri M, et al: A MicroRNA signature associated with prognosis and progression in chronic lymphocytic leukemia. N Engl J Med 353: 1793-1801, 2005.

225. Esquela-Kerscher A and Slack FJ: Oncomirs - microRNAs with a role in cancer. Nat Rev Cancer 6: 259-269, 2006.

226. Iorio MV, Ferracin M, Liu CG, Veronese A, Spizzo R, Sabbioni S, Magri E, Pedriali M, Fabbri M, Campiglio M, et al: MicroRNA gene expression deregulation in human breast cancer. Cancer Res 65: 7065-7070, 2005.

227. Iorio MV, Visone R, Di Leva G, Donati V, Petrocca F, Casalini P, Taccioli C, Volinia S, Liu CG, Alder H, et al: MicroRNA signatures in human ovarian cancer. Cancer Res 67: 8699-8707, 2007.

228. Porkka KP, Pfeiffer MJ, Waltering KK, Vessella RL, Tammela TL and Visakorpi T: MicroRNA expression profiling in prostate cancer. Cancer Res 67: 6130-6135, 2007.

229. Meng F, Henson R, Wehbe-Janek H, Ghoshal K, Jacob ST and Patel T: MicroRNA-21 regulates expression of the PTEN tumor suppressor gene in human hepatocellular cancer. Gastroenterology 133: 647-658, 2007.

230.Zhu S, Si ML, Wu H and Mo YY: MicroRNA-21 targets the tumor suppressor gene tropomyosin 1 (TPM1). J Biol Chem 282: 14328-14336, 2007

231. Frankel LB, Christoffersen NR, Jacobsen A, Lindow M, Krogh A and Lund AH: Programmed cell death 4 (PDCD4) is an important functional target of the microRNA miR-21 in breast cancer cells. J Biol Chem 283: 1026-1033, 2008.

232. Garzon R, Volinia S, Liu CG, Fernandez-Cymering C, Palumbo T, Pichiorri F, Fabbri M, Coombes K, Alder H, Nakamura T, et al: MicroRNA signatures associated with cytogenetics and prognosis in acute myeloid leukemia. Blood 111: 3183-3189, 2008.

233. Volinia S, Calin GA, Liu CG, Ambs S, Cimmino A, Petrocca F, Visone R, Iorio M, Roldo C, Ferracin M, et al: A microRNA expression signature of human solid tumors defines cancer gene targets. Proc Natl Acad Sci USA 103: 2257-2261, 2006.

234. White NM, Fatoohi E, Metias M, Jung K, Stephan C and Yousef GM: Metastamirs: A stepping stone towards improved cancer management. Nat Rev Clin Oncol 8: 75-84, 2011.

235. Zhou L, Liu F, Wang X and Ouyang G: The roles of microRNAs in the regulation of tumor metastasis. Cell Biosci 5: 32, 2015.

236. Wang XH, Cai P, Wang MH and Wang Z: microRNA 25 promotes osteosarcoma cell proliferation by targeting the cell cycle inhibitor p27. Mol Med Rep 10: 855-859, 2014.

237. Siu MK, Tsai YC, Chang YS, Yin JJ, Suau F, Chen WY and Liu YN: Transforming growth factor- $\beta$ promotes prostate bone metastasis through induction of microRNA-96 and activation of the mTOR pathway. Oncogene 34: 4767-4776, 2015.

238. Xia X, Li Y, Wang W, Tang F, Tan J, Sun L, Li Q, Sun L, Tang B and He S: MicroRNA-1908 functions as a glioblastoma oncogene by suppressing PTEN tumor suppressor pathway. Mol Cancer 14: 154, 2015.

239. Sachdeva M, Mito JK, Lee CL, Zhang M, Li Z, Dodd RD, Cason D, Luo L, Ma Y, Van Mater D, et al: MicroRNA-182 drives metastasis of primary sarcomas by targeting multiple genes. J Clin Invest 124: 4305-4319, 2014. 
240. Tian Y, Luo A, Cai Y, Su Q, Ding F, Chen H and Liu Z: MicroRNA-10b promotes migration and invasion through KLF4 in human esophageal cancer cell lines. J Biol Chem 285: 7986-7994, 2010.

241. Wang YY, Ye ZY, Zhao ZS, Li L, Wang YX, Tao HQ, Wang HJ and $\mathrm{He} \mathrm{XJ}$ : Clinicopathologic significance of miR-10b expression in gastric carcinoma. Hum Pathol 44: 1278-1285, 2013.

242. Chan JA, Krichevsky AM and Kosik KS: MicroRNA-21 is an antiapoptotic factor in human glioblastoma cells. Cancer Res 65: 6029-6033, 2005.

243.Liu W, Zabirnyk O, Wang H, Shiao YH, Nickerson ML, Khalil S, Anderson LM, Perantoni AO and Phang JM: miR-23b targets proline oxidase, a novel tumor suppressor protein in renal cancer. Oncogene 29: 4914-4924, 2010.

244. Fletcher CE, Dart DA, Sita-Lumsden A, Cheng H, Rennie PS and Bevan CL: Androgen-regulated processing of the oncomir miR-27a, which targets Prohibitin in prostate cancer. Hum Mol Genet 21: 3112-3127, 2012.

245. Ng WL, Yan D, Zhang X, Mo YY and Wang Y: Over-expression of miR-100 is responsible for the low-expression of ATM in the human glioma cell line: M059J. DNA Repair (Amst) 9: 1170-1175, 2010

246.Zheng YS, Zhang H, Zhang XJ, Feng DD, Luo XQ, Zeng CW, Lin KY, Zhou H, Qu LH, Zhang P, et al: MiR-100 regulates cel differentiation and survival by targeting RBSP3, a phosphataselike tumor suppressor in acute myeloid leukemia. Oncogene 31 $80-92,2012$

247. Knackmuss U, Lindner SE, Aneichyk T, Kotkamp B, Knust Z, Villunger A and Herzog S: MAP3K11 is a tumor suppressor targeted by the oncomiR miR-125b in early B cells. Cell Death Differ 23: 242-252, 2016.

248.Park JK, Henry JC, Jiang J, Esau C, Gusev Y, Lerner MR Postier RG, Brackett DJ and Schmittgen TD: miR-132 and miR-212 are increased in pancreatic cancer and target the retinoblastoma tumor suppressor. Biochem Biophys Res Commun 406: 518-523, 2011.

249. Kong W, He L, Coppola M, Guo J, Esposito NN, Coppola D and Cheng JQ: MicroRNA-155 regulates cell survival, growth, and chemosensitivity by targeting FOXO3a in breast cancer. J Biol Chem 285: 17869-17879, 2010.

250. Jiang S, Zhang HW, Lu MH, He XH, Li Y, Gu H, Liu MF and Wang ED: MicroRNA-155 functions as an OncomiR in breas cancer by targeting the suppressor of cytokine signaling 1 gene. Cancer Res 70: 3119-3127, 2010.

251.Czyzyk-Krzeska MF and Zhang X: MiR-155 at the heart of oncogenic pathways. Oncogene 33: 677-678, 2014.

252. Wang $\mathrm{J}$ and $\mathrm{Wu} \mathrm{J}$ : Role of miR-155 in breast cancer. Front Biosci (Landmark Ed) 17: 2350-2355, 2012.

253.Ling N, Gu J, Lei Z, Li M, Zhao J, Zhang HT and Li X: microRNA-155 regulates cell proliferation and invasion by targeting FOXO3a in glioma. Oncol Rep 30: 2111-2118, 2013.

254. Musilova K and Mraz M: MicroRNAs in B-cell lymphomas: How a complex biology gets more complex. Leukemia 29 : 1004-1017, 2015.

255. Fontana L, Fiori ME, Albini S, Cifaldi L, Giovinazzi S, Forloni M, Boldrini R, Donfrancesco A, Federici V, Giacomini P, et al: AntagomiR-17-5p abolishes the growth of therapy-resistant neuroblastoma through p21 and BIM.PLoS One 3: e2236, 2008.

256. Segura MF, Hanniford D, Menendez S, Reavie L, Zou X, Alvarez-Diaz S, Zakrzewski J, Blochin E, Rose A, Bogunovic D, et al: Aberrant miR-182 expression promotes melanoma metastasis by repressing FOXO3 and microphthalmia-associated transcription factor. Proc Natl Acad Sci USA 106: 1814-1819, 2009.

257. Yang H, Kong W, He L, Zhao JJ, O'Donnell JD, Wang J, Wenham RM, Coppola D, Kruk PA, Nicosia SV, et al: MicroRNA expression profiling in human ovarian cancer: miR-214 induces cell survival and cisplatin resistance by targeting PTEN. Cancer Res 68: 425-433, 2008

258.Zhang CZ, Zhang JX, Zhang AL, Shi ZD, Han L, Jia ZF, Yang WD, Wang GX, Jiang T, You YP, et al: MiR-221 and miR-222 target PUMA to induce cell survival in glioblastoma. Mol Cancer 9: 229, 2010.

259. Garofalo M,Quintavalle C, Romano G,Croce CM and Condorelli G: miR221/222 in cancer: Their role in tumor progression and response to therapy. Curr Mol Med 12: 27-33, 2012.

260. Quintavalle C, Garofalo M, Zanca C, Romano G, Iaboni M, del Basso De Caro M, Martinez-Montero JC, Incoronato M, Nuovo G, Croce CM, et al: miR-221/222 overexpession in human glioblastoma increases invasiveness by targeting the protein phosphate $\mathrm{PTP} \mu$. Oncogene 31: 858-868, 2012.
261. Chen WX, Hu Q, Qiu MT, Zhong SL, Xu JJ, Tang JH and Zhao JH: miR-221/222: Promising biomarkers for breast cancer. Tumour Biol 34: 1361-1370, 2013.

262. Matsuzaki J and Suzuki H: Role of MicroRNAs-221/222 in digestive systems. J Clin Med 4: 1566-1577, 2015.

263. Würdinger T, Tannous BA, Saydam O, Skog J, Grau S, Soutschek J, Weissleder R, Breakefield XO and Krichevsky AM: miR-296 regulates growth factor receptor overexpression in angiogenic endothelial cells. Cancer Cell 14: 382-393, 2008

264. Shi W, Gerster K, Alajez NM, Tsang J, Waldron L, Pintilie M, Hui AB, Sykes J, P'ng C, Miller N, et al: MicroRNA-301 mediates proliferation and invasion in human breast cancer. Cancer Res 71: 2926-2937, 2011.

265. Voorhoeve PM, le Sage C, Schrier M, Gillis AJ, Stoop H, Nagel R, Liu YP, van Duijse J, Drost J, Griekspoor A, et al: A genetic screen implicates miRNA-372 and miRNA-373 as oncogenes in testicular germ cell tumors. Adv Exp Med Biol 604: 17-46, 2007.

266. Xu Y, Jin J, Liu Y, Huang Z, Deng Y, You T, Zhou T, Si J and Zhuo W: Snail-regulated MiR-375 inhibits migration and invasion of gastric cancer cells by targeting JAK2. PLoS One 9: e99516, 2014.

267.Lee DY, Deng Z, Wang CH and Yang BB: MicroRNA-378 promotes cell survival, tumor growth, and angiogenesis by targeting SuFu and Fus-1 expression. Proc Natl Acad Sci USA 104: 20350-20355, 2007.

268. Tu K, Liu Z, Yao B, Han S and Yang W: MicroRNA-519a promotes tumor growth by targeting PTEN/PI3K/AKT signaling in hepatocellular carcinoma. Int J Oncol 48: 965-974, 2016.

269. Shao J, Cao J, Liu Y, Mei H, Zhang Y and Xu W: MicroRNA-519a promotes proliferation and inhibits apoptosis of hepatocellular carcinoma cells by targeting FOXF2. FEBS Open Bio 5: 893-899, 2015

270. Ward A, Shukla K, Balwierz A, Soons Z, König R, Sahin O and Wiemann S: MicroRNA-519a is a novel oncomir conferring tamoxifen resistance by targeting a network of tumoursuppressor genes in $\mathrm{ER}^{+}$breast cancer. J Pathol 233: 368-379, 2014.

271. Tsang WP, Ng EK, Ng SS, Jin H, Yu J, Sung JJ and Kwok TT: Oncofetal H19-derived miR-675 regulates tumor suppressor RB in human colorectal cancer. Carcinogenesis 31: 350-358, 2010.

272. Ma L, Young J, Prabhala H, Pan E, Mestdagh P, Muth D, Teruya-Feldstein J, Reinhardt F, Onder TT, Valastyan S, et al: $\mathrm{miR}-9$, a MYC/MYCN-activated microRNA, regulates E-cadherin and cancer metastasis. Nat Cell Biol 12: 247-256, 2010.

273. Chen D, Sun Y, Wei Y, Zhang P, Rezaeian AH, TeruyaFeldstein J, Gupta S, Liang H, Lin HK, Hung MC, et al: LIFR is a breast cancer metastasis suppressor upstream of the Hippo-YAP pathway and a prognostic marker. Nat Med 18: 1511-1517, 2012

274. White RA, Neiman JM, Reddi A, Han G, Birlea S, Mitra D, Dionne L, Fernandez P, Murao K, Bian L, et al: Epithelial stem cell mutations that promote squamous cell carcinoma metastasis. J Clin Invest 123: 4390-4404, 2013.

275. Ma L, Teruya-Feldstein J and Weinberg RA: Tumour invasion and metastasis initiated by microRNA-10b in breast cancer. Nature 449: 682-688, 2007.

276. Lin J, Teo S, Lam DH, Jeyaseelan K and Wang S: MicroRNA-10b pleiotropically regulates invasion, angiogenicity and apoptosis of tumor cells resembling mesenchymal subtype of glioblastoma multiforme. Cell Death Dis 3: e398, 2012.

277. Zhang WL, Zhang JH, Wu XZ, Yan T and Lv W: miR-15b promotes epithelial-mesenchymal transition by inhibiting SMURF2 in pancreatic cancer. Int J Oncol 47: 1043-1053, 2015.

278. Wu Q, Yang Z, An Y, Hu H, Yin J, Zhang P, Nie Y, Wu K, Shi Y and Fan D: MiR-19a/b modulate the metastasis of gastric cancer cells by targeting the tumour suppressor MXD1. Cell Death Dis 5: e1144, 2014.

279. Chang Y, Liu C, Yang J, Liu G, Feng F, Tang J, Hu L, Li L, Jiang F, Chen C, et al: MiR-20a triggers metastasis of gallbladder carcinoma. J Hepatol 59: 518-527, 2013.

280. Zhao S, Yao D, Chen J, Ding N and Ren F: MiR-20a promotes cervical cancer proliferation and metastasis in vitro and in vivo. PLoS One 10: e0120905, 2015.

281. Dean ZS, Riahi R and Wong PK: Spatiotemporal dynamics of microRNA during epithelial collective cell migration. Biomaterials 37: 156-163, 2015.

282. Peacock O, Lee AC, Cameron F, Tarbox R, Vafadar-Isfahani N, Tufarelli $\mathrm{C}$ and Lund JN: Inflammation and MiR-21 pathways functionally interact to downregulate PDCD4 in colorectal cancer. PLoS One 9: e110267, 2014. 
283.Xu J, Zhang W, Lv Q and Zhu D: Overexpression of miR-21 promotes the proliferation and migration of cervical cancer cells via the inhibition of PTEN. Oncol Rep 33: 3108-3116, 2015.

284. Asangani IA, Rasheed SA, Nikolova DA, Leupold JH, Colburn NH, Post S and Allgayer H: MicroRNA-21 (miR-21) post-transcriptionally downregulates tumor suppressor Pded4 and stimulates invasion, intravasation and metastasis in colorectal cancer. Oncogene 27: 2128-2136, 2008.

285. Melnik BC: MiR-21: An environmental driver of malignant melanoma? J Transl Med 13: 202, 2015.

286.Zhou W, Fong MY, Min Y, Somlo G, Liu L, Palomares MR, Yu Y, Chow A, O'Connor ST, Chin AR, et al: Cancer-secreted miR-105 destroys vascular endothelial barriers to promote metastasis. Cancer Cell 25: 501-515, 2014.

287. Fong MY, Zhou W, Liu L, Alontaga AY, Chandra M, Ashby J, Chow A, O'Connor ST, Li S, Chin AR, et al: Breastcancer-secreted miR-122 reprograms glucose metabolism in premetastatic niche to promote metastasis. Nat Cell Biol 17: 183-194, 2015

288. Lin CW, Chang YL, Chang YC, Lin JC, Chen CC, Pan SH, Wu CT, Chen HY, Yang SC, Hong TM, et al: MicroRNA-135b promotes lung cancer metastasis by regulating multiple targets in the Hippo pathway and LZTS1. Nat Commun 4: 1877, 2013.

289. Taylor MA, Sossey-Alaoui K, Thompson CL, Danielpour D and Schiemann WP: TGF- $\beta$ upregulates miR-181a expression to promote breast cancer metastasis. J Clin Invest 123: 150-163, 2013.

290. Qiu Y, Luo X, Kan T, Zhang Y, Yu W, Wei Y, Shen N, Yi B and Jiang X: TGF- $\beta$ upregulates miR-182 expression to promote gallbladder cancer metastasis by targeting CADM1. Mol Biosyst 10: 679-685, 2014.

291. Ren LH, Chen WX, Li S, He XY, Zhang ZM, Li M, Cao RS, Hao B, Zhang HJ, Qiu HQ, et al: MicroRNA-183 promotes proliferation and invasion in oesophageal squamous cell carcinoma by targeting programmed cell death 4. Br J Cancer 111: 2003-2013, 2014.

292. Korpal M, Lee ES, Hu G and Kang Y: The miR-200 family inhibits epithelial-mesenchymal transition and cancer cell migration by direct targeting of E-cadherin transcriptional repressors ZEB1 and ZEB2. J Biol Chem 283: 14910-14914, 2008.

293. Korpal M, Ell BJ, Buffa FM, Ibrahim T, Blanco MA, Celià-Terrassa T, Mercatali L, Khan Z, Goodarzi H, Hua Y, et al: Direct targeting of Sec23a by miR-200s influences cancer cell secretome and promotes metastatic colonization. Nat Med 17: 1101-1108, 2011.

294.Park SM, Gaur AB, Lengyel E and Peter ME: The miR-200 family determines the epithelial phenotype of cancer cells by targeting the E-cadherin repressors ZEB1 and ZEB2. Genes Dev 22: 894-907, 2008.

295. Gregory PA, Bert AG, Paterson EL, Barry SC, Tsykin A, Farshid G, Vadas MA, Khew-Goodall Y and Goodall GJ: The miR-200 family and miR-205 regulate epithelial to mesenchymal transition by targeting ZEB1 and SIP1. Nat Cell Biol 10 593-601, 2008.

296. Penna E, Orso F, Cimino D, Tenaglia E, Lembo A, Quaglino E Poliseno L, Haimovic A, Osella-Abate S, De Pittà C, et al microRNA-214 contributes to melanoma tumour progression through suppression of TFAP2C. EMBO J 30: 1990-2007, 2011

297. Penna E, Orso F, Cimino D, Vercellino I, Grassi E, Quaglino E, Turco E and Taverna D: miR-214 coordinates melanoma progression by upregulating ALCAM through TFAP2 and miR-148b downmodulation. Cancer Res 73: 4098-4111, 2013.

298. Long H, Wang Z, Chen J, Xiang T, Li Q, Diao X and Zhu B microRNA-214 promotes epithelial-mesenchymal transition and metastasis in lung adenocarcinoma by targeting the suppressorof-fused protein (Sufu). Oncotarget 6: 38705-38718, 2015.

299. Liu X, Chen Q, Yan J, Wang Y, Zhu C, Chen C, Zhao X, Xu M, Sun Q, Deng R, et al: MiRNA-296-3p-ICAM-1 axis promotes metastasis of prostate cancer by possible enhancing survival of natural killer cell-resistant circulating tumour cells. Cell Death Dis 4: e928, 2013

300. Vaira V, Faversani A, Martin NM, Garlick DS, Ferrero S, Nosotti M, Kissil JL, Bosari S and Altieri DC: Regulation of lung cancer metastasis by Klf4-Numb-like signaling. Cancer Res 73: 2695-2705, 2013

301. Ni F, Zhao H, Cui H, Wu Z, Chen L, Hu Z, Guo C, Liu Y, Chen Z, Wang X, et al: MicroRNA-362-5p promotes tumor growth and metastasis by targeting CYLD in hepatocellular carcinoma. Cancer Lett 356: 809-818, 2015
302. Chen D, Dang BL, Huang JZ, Chen M, Wu D, Xu ML, Li R and Yan GR: MiR-373 drives the epithelial-to-mesenchymal transition and metastasis via the miR-373-TXNIP-HIF1 $\alpha$-TWIST signaling axis in breast cancer. Oncotarget 6: 32701-32712, 2015.

303. Lu S, Zhu Q, Zhang Y, Song W, Wilson MJ and Liu P: Dual-functions of miR-373 and miR-520c by differently regulating the activities of MMP2 and MMP9. J Cell Physiol 230: 1862-1870, 2015.

304. Glover AR, Zhao JT, Gill AJ, Weiss J, Mugridge N, Kim E, Feeney AL, Ip JC, Reid G, Clarke S, et al: MicroRNA-7 as a tumor suppressor and novel therapeutic for adrenocortical carcinoma. Oncotarget 6: 36675-36688, 2015.

305. Babae N, Bourajiaj M, Liu Y, Van Beijnum JR, Cerisoli F, Scaria PV, Verheul M, Van Berkel MP, Pieters EH, Van Haastert RJ, et al: Systemic miRNA-7 delivery inhibits tumor angiogenesis and growth in murine xenograft glioblastoma. Oncotarget 5: 6687-6700, 2014.

306. Wang W, Dai LX, Zhang S, Yang Y, Yan N, Fan P, Dai L, Tian HW, Cheng L, Zhang XM, et al: Regulation of epidermal growth factor receptor signaling by plasmid-based microRNA-7 inhibits human malignant gliomas growth and metastasis in vivo. Neoplasma 60: 274-283, 2013.

307. Cortez MA, Valdecanas D, Zhang X, Zhan Y, Bhardwaj V, Calin GA, Komaki R, Giri DK, Quini CC, Wolfe T, et al: Therapeutic delivery of miR-200c enhances radiosensitivity in lung cancer. Mol Ther 22: 1494-1503, 2014.

308. Wu X, Liu T, Fang O, Dong W, Zhang F, Leach L, Hu X and Luo Z: MicroRNA-708-5p acts as a therapeutic agent against metastatic lung cancer. Oncotarget 7: 2417-2432, 2016.

309. Ge YF, Sun J, Jin CJ, Cao BQ, Jiang ZF and Shao JF: AntagomiR-27a targets FOXO3a in glioblastoma and suppresses U87 cell growth in vitro and in vivo. Asian Pac J Cancer Prev 14: 963-968, 2013

310. Shu M, Zheng X, Wu S, Lu H, Leng T, Zhu W, Zhou Y, Ou Y, Lin X, Lin Y, et al: Targeting oncogenic miR-335 inhibits growth and invasion of malignant astrocytoma cells. Mol Cancer 10: 59, 2011.

311. Rather MI, Nagashri MN, Swamy SS, Gopinath KS and Kumar A: Oncogenic microRNA-155 down-regulates tumor suppressor CDC73 and promotes oral squamous cell carcinoma cell proliferation: Implications for cancer therapeutics. J Biol Chem 288: 608-618, 2013.

312. Haug BH, Henriksen JR, Buechner J, Geerts D, Tømte E, Kogner P, Martinsson T, Flægstad T, Sveinbjørnsson B and Einvik C: MYCN-regulated miRNA-92 inhibits secretion of the tumor suppressor DICKKOPF-3 (DKK3) in neuroblastoma. Carcinogenesis 32: 1005-1012, 2011.

313. Tang H, Liu X, Wang Z, She X, Zeng X, Deng M, Liao Q, Guo X, Wang R, Li X, et al: Interaction of hsa-miR-381 and glioma suppressor LRRC4 is involved in glioma growth. Brain Res 1390: 21-32, 2011.

314. Ma L, Reinhardt F, Pan E, Soutschek J, Bhat B, Marcusson EG, Teruya-Feldstein J, Bell GW and Weinberg RA: Therapeutic silencing of miR-10b inhibits metastasis in a mouse mammary tumor model. Nat Biotechnol 28: 341-347, 2010.

315. Mercatelli N, Coppola V, Bonci D, Miele F, Costantini A, Guadagnoli M, Bonanno E, Muto G, Frajese GV, De Maria R, et al: The inhibition of the highly expressed miR-221 and miR-222 impairs the growth of prostate carcinoma xenografts in mice. PLoS One 3: e4029, 2008.

316.Zhao Y, Zhao L, Ischenko I, Bao Q, Schwarz B, Nieß H, Wang Y, Renner A, Mysliwietz J, Jauch KW, et al: Antisense inhibition of microRNA-21 and microRNA-221 in tumorinitiating stem-like cells modulates tumorigenesis, metastasis, and chemotherapy resistance in pancreatic cancer. Target Oncol 10: 535-548, 2015

317. Wagenaar TR, Zabludoff S, Ahn SM, Allerson C, Arlt H, Baffa R, Cao H, Davis S, Garcia-Echeverria C, Gaur R, et al: Anti-miR-21 suppresses hepatocellular carcinoma growth via broad transcriptional network deregulation. Mol Cancer Res 13: 1009-1021, 2015.

318. Fabani MM, Abreu-Goodger C, Williams D, Lyons PA, Torres AG, Smith KG, Enright AJ, Gait MJ and Vigorito E: Efficient inhibition of miR-155 function in vivo by peptide nucleic acids. Nucleic Acids Res 38: 4466-4475, 2010.

319. Brognara E, Fabbri E, Aimi F, Manicardi A, Bianchi N, Finotti A, Breveglieri G, Borgatti M, Corradini R, Marchelli R, et al: Peptide nucleic acids targeting miR-221 modulate p27 $7^{\mathrm{Kip}}$ expression in breast cancer MDA-MB-231 cells. Int J Oncol 41: 2119-2127, 2012 
320. Yan LX, Wu QN, Zhang Y, Li YY, Liao DZ, Hou JH, Fu J, Zeng MS, Yun JP, Wu QL, et al: Knockdown of miR-21 in human breast cancer cell lines inhibits proliferation, in vitro migration and in vivo tumor growth. Breast Cancer Res 13: R2, 2011.

321.Zhang J and Ma L: MicroRNA control of epithelial-mesenchymal transition and metastasis. Cancer Metastasis Rev 31: 653-662, 2012.

322. Zaravinos A, Radojicic J, Lambrou GI, Volanis D, Delakas D, Stathopoulos EN and Spandidos DA: Expression of miRNAs involved in angiogenesis, tumor cell proliferation, tumor suppressor inhibition, epithelial-mesenchymal transition and activation of metastasis in bladder cancer. J Urol 188: 615-623, 2012.

323. Kiesslich T, Pichler M and Neureiter D: Epigenetic control of epithelial-mesenchymal-transition in human cancer. Mol Clin Oncol 1: 3-11,2013.

324.Lei C, Wang Y, Huang Y, Yu H, Huang Y, Wu L and Huang L: Up-regulated miR155 reverses the epithelial-mesenchymal transition induced by EGF and increases chemo-sensitivity to cisplatin in human Caski cervical cancer cells. PLoS One 7: e52310, 2012.

325.Koutsaki M, Spandidos DA and Zaravinos A: Epithelialmesenchymal transition-associated miRNAs in ovarian carcinoma, with highlight on the miR-200 family: Prognostic value and prospective role in ovarian cancer therapeutics. Cancer Lett 351: 173-181, 2014.

326. Gao H, Teng C, Huang W, Peng J and Wang C: SOX2 promotes the epithelial to mesenchymal transition of esophageal squamous cells by modulating Slug expression through the activation of STAT3/HIF- $\alpha$ signaling.

327.Lambertini E, Lolli A, Vezzali F, Penolazzi L, Gambari R and Piva R: Correlation between Slug transcription factor and miR-221 in MDA-MB-231 breast cancer cells. BMC Cancer 12 445, 2012.

328. Qiu G, Lin Y, Zhang $\mathrm{H}$ and Wu D: miR-139-5p inhibits epithelial-mesenchymal transition, migration and invasion of hepatocellular carcinoma cells by targeting ZEB1 and ZEB2 Biochem Biophys Res Commun 463: 315-321, 2015.

329. Bezzerri V, Borgatti M, Finotti A, Tamanini A, Gambari R and Cabrini G: Mapping the transcriptional machinery of the IL-8 gene in human bronchial epithelial cells. J Immunol 187: 6069-6081, 2011.

330. Raychaudhuri B and Vogelbaum MA: IL-8 is a mediator of $\mathrm{NF}-\kappa \mathrm{B}$ induced invasion by gliomas. J Neurooncol 101: 227-235, 2011

331.Xie TX, Xia Z, Zhang N, Gong W and Huang S: Constitutive $\mathrm{NF}-\kappa \mathrm{B}$ activity regulates the expression of VEGF and IL-8 and tumor angiogenesis of human glioblastoma. Oncol Rep 23 725-732, 2010.

332. Sun S, Wang Q, Giang A, Cheng C, Soo C, Wang CY, Liau LM and Chiu R: Knockdown of CypA inhibits interleukin-8 (IL-8) and IL-8-mediated proliferation and tumor growth of glioblastoma cells through down-regulated NF-кB. J Neurooncol 101: 1-14, 2011

333. Gabellini C, Castellini L, Trisciuoglio D, Kracht M, Zupi G and Del Bufalo D: Involvement of nuclear factor-kappa B in bcl-xL-induced interleukin 8 expression in glioblastoma. $\mathrm{J}$ Neurochem 107: 871-882, 2008

334. Yang TQ, Lu XJ, Wu TF, Ding DD, Zhao ZH, Chen GL, Xie XS Li B, Wei YX, Guo LC, et al: MicroRNA-16 inhibits glioma cell growth and invasion through suppression of BCL2 and the nuclear factor-кB1/MMP9 signaling pathway. Cancer Sci 105: 265-271, 2014

335. Fang L, Deng Z, Shatseva T, Yang J, Peng C, Du WW, Yee AJ, Ang LC, He C, Shan SW, et al: MicroRNA miR-93 promotes tumor growth and angiogenesis by targeting integrin- $\beta 8$. Oncogene 30: 806-821, 2011.

336. Magge SN, Malik SZ, Royo NC, Chen HI, Yu L, Snyder EY, O'Rourke DM and Watson DJ: Role of monocyte chemoattractant protein-1 (MCP-1/CCL2) in migration of neural progenitor cells toward glial tumors. J Neurosci Res 87: 1547-1555, 2009.

337. Nazarenko I, Hede SM, He X, Hedrén A, Thompson J, Lindström MS and Nistér M: PDGF and PDGF receptors in glioma. Ups J Med Sci 117: 99-112, 2012.

338. Cai JJ, Qi ZX, Chen LC, Yao Y and Gong Y and Mao Y: miR-124 suppresses the migration and invasion of glioma cells in vitro via Capn4. Oncol Rep 35: 284-290, 2015.

339. Cheng Y, Li Y, Nian Y, Liu D, Dai F and Zhang J: STAT3 is involved in miR-124-mediated suppressive effects on esophageal cancer cells. BMC Cancer 15: 306, 2015.
340. Dong LL, Chen LM, Wang WM, Zhang LM: Decreased expression of microRNA-124 is an independent unfavorable prognostic factor for patients with breast cancer. Diagn Pathol 10: 45, 2015

341.Long QZ, Du YF, Liu XG, Li X and He DL: miR-124 represses FZD5 to attenuate P-glycoprotein-mediated chemo-resistance in renal cell carcinoma. Tumour Biol 36: 7017-7026, 2015.

342. Lu SH, Jiang XJ, Xiao GL, Liu DY and Yuan XR: miR-124a restoration inhibits glioma cell proliferation and invasion by suppressing IQGAP1 and $\beta$-catenin. Oncol Rep 32: 2104-2110, 2014.

343. Chen SM, Chou WC, Hu LY, Hsiung CN, Chu HW, Huang YL, Hsu HM, Yu JC and Shen CY: The Effect of MicroRNA-124 overexpression on anti-tumor drug sensitivity. PLoS One 10: e0128472, 2015

344. Fabbri E, Brognara E, Montagner G, Ghimenton C, Eccher A, Cantù C, Khalil S, Bezzerri V, Provezza L, Bianchi N, et al: Regulation of IL-8 gene expression in gliomas by microRNA miR-93. BMC Cancer 15: 661, 2015.

345. Fabbri E, Montagner G, Bianchi N, Finotti A, Borgatti M, Lampronti I, Cabrini G and Gambari R: MicroRNA miR-93-5p regulates expression of IL-8 and VEGF in neuroblastoma SK-N-AS cells. Oncol Rep 35: 2866-2872, 2016.

346. Galardi S, Mercatelli N, Giorda E, Massalini S, Frajese GV, Ciafrè SA and Farace MG: miR-221 and miR-222 expression affects the proliferation potential of human prostate carcinoma cell lines by targeting p27 ${ }^{\text {Kip1 }}$. J Biol Chem 282: 23716-23724, 2007.

347. Lu X, Zhao P, Zhang C, Fu Z, Chen Y, Lu A, Liu N, You Y, Pu P and Kang C: Analysis of miR-221 and p27 expression in human gliomas. Mol Med Rep 2: 651-656, 2009.

348. Gillies JK and Lorimer IA: Regulation of $\mathrm{p} 27^{\mathrm{Kipl}}$ by miRNA 221/222 in glioblastoma. Cell Cycle 6: 2005-2009, 2007.

349. Wang Y, Wang X, Zhang J, Sun G, Luo H, Kang C, Pu P, Jiang T, Liu N and You Y: MicroRNAs involved in the EGFR/PTEN/ AKT pathway in gliomas. J Neurooncol 106: 217-224, 2012.

350. Ueda R,Kohanbash G, Sasaki K,Fujita M,Zhu X, KastenhuberER, McDonald HA, Potter DM, Hamilton RL, Lotze MT, et al: Dicerregulated microRNAs 222 and 339 promote resistance of cancer cells to cytotoxic T-lymphocytes by down-regulation of ICAM-1. Proc Natl Acad Sci USA 106: 10746-10751, 2009.

351.Zhang J, Han L, Ge Y, Zhou X, Zhang A, Zhang C, Zhong Y, You Y, Pu P and Kang C: miR-221/222 promote malignant progression of glioma through activation of the Akt pathway. Int J Oncol 36: 913-920, 2010

352.Zhang C, Jiang T, Wang J, Cheng J, Pu P and Kang C: MiR-221/222 promote the growth of malignant glioma cells by regulating its target genes, molecular targets of CNS tumors. Dr Miklos Garami (Ed). ISBN: 978-953-307-736-9. InTech, pp461-482, 2011.

353. Sarkar S, Dubaybo H, Ali S, Goncalves P, Kollepara SL, Sethi S, Philip PA and Li Y: Down-regulation of miR-221 inhibits proliferation of pancreatic cancer cells through up-regulation of PTEN, p27(kip1), p57(kip2), and PUMA. Am J Cancer Res 3: 465-477, 2013

354.Zhang C, Kang C, You Y, Pu P, Yang W, Zhao P, Wang G, Zhang A, Jia Z, Han L, et al: Co-suppression of miR-221/222 cluster suppresses human glioma cell growth by targeting $\mathrm{p} 27^{\mathrm{Kip} 1}$ in vitro and in vivo. Int J Oncol 34: 1653-1660, 2009.

355. Zhang R, Pang B, Xin T, Guo H, Xing Y, Xu S, Feng B, Liu B and Pang Q: Plasma miR-221/222 family as novel descriptive and prognostic biomarkers for glioma. Mol Neurobiol 53: 1452-1460, 2016.

356. Yang Y, Li F, Saha MN, Abdi J, Qiu L and Chang H: miR-137/197 induce apoptosis and suppress tumorigenicity by targeting MCL-1 in multiple myeloma. Clin Cancer Res 21: 2399-2411, 2015.

357. Lee SH, Jung YD, Choi YS and Lee YM: Targeting of RUNX3 by miR-130a and miR-495 cooperatively increases cell proliferation and tumor angiogenesis in gastric cancer cells. Oncotarget 6: 33269-33278, 2015.

358. Brognara E, Fabbri E, Montagner G, Gasparello J, Manicardi A, Corradini R, Bianchi N, Finotti A, Breveglieri G, Borgatti M, et al: High levels of apoptosis are induced in human glioma cell lines by co-administration of peptide nucleic acids targeting miR-221 and miR-222. Int J Oncol 48: 1029-1038, 2016.

359. GiuntiL, da Ros M, Vinci S, Gelmini S, Iorio AL, Buccoliero AM, Cardellicchio S, Castiglione F, Genitori L, de Martino M, et al: Anti-miR21 oligonucleotide enhances chemosensitivity of T98G cell line to doxorubicin by inducing apoptosis. Am J Cancer Res 5: 231-242, 2014 
360. Gao C, Peng FH and Peng LK: MiR-200c sensitizes clear-cell renal cell carcinoma cells to sorafenib and imatinib by targeting heme oxygenase-1. Neoplasma 61: 680-689, 2014.

361.Pogribny IP, Filkowski JN, Tryndyak VP, Golubov A, Shpyleva SI and Kovalchuk O: Alterations of microRNAs and their targets are associated with acquired resistance of MCF-7 breast cancer cells to cisplatin. Int J Cancer 127: 1785-1794, 2010.

362. Suto T, Yokobori T, Yajima R, Morita H, Fujii T, Yamaguchi S, Altan B, Tsutsumi S, Asao T and Kuwano H: MicroRNA-7 expression in colorectal cancer is associated with poor prognosis and regulates cetuximab sensitivity via EGFR regulation. Carcinogenesis 36: 338-345, 2015.

363. Liu R, Liu X, Zheng Y, Gu J, Xiong S, Jiang P, Jiang X, Huang E, Yang Y, Ge D, et al: MicroRNA-7 sensitizes non-small cell lung cancer cells to paclitaxel. Oncol Lett 8: 2193-2200, 2014.

364. Gomes SE, Simões AE, Pereira DM, Castro RE, Rodrigues CM and Borralho PM: miR-143 or miR-145 overexpression increases cetuximab-mediated antibody-dependent cellular cytotoxicity in human colon cancer cells. Oncotarget: Jan 25, 2016 (Epub ahead of print).

365. Costa PM, Cardoso AL, Nóbrega C, Pereira de Almeida LF, Bruce JN, Canoll P and Pedroso de Lima MC: MicroRNA-21 silencing enhances the cytotoxic effect of the antiangiogenic drug sunitinib in glioblastoma. Hum Mol Genet 22: 904-918, 2013.

366. Qian X, Ren Y, Shi Z, Long L, Pu P, Sheng J, Yuan X and Kang C: Sequence-dependent synergistic inhibition of human glioma cell lines by combined temozolomide and miR-21 inhibitor gene therapy. Mol Pharm 9: 2636-2645, 2012.
367. Zhang S, Han L, Wei J, Shi Z, Pu P, Zhang J, Yuan X and Kang C: Combination treatment with doxorubicin and microRNA-21 inhibitor synergistically augments anticancer activity through upregulation of tumor suppressing genes. Int J Oncol 46: 1589-1600, 2015.

368. Zhang Q, Ran R, Zhang L, Liu Y, Mei L, Zhang Z, Gao H and He Q: Simultaneous delivery of therapeutic antagomirs with paclitaxel for the management of metastatic tumors by a $\mathrm{pH}$-responsive anti-microbial peptide-mediated liposomal delivery system. J Control Release 197: 208-218, 2015.

369. Fan L, Yang Q, Tan J, Qiao Y, Wang Q, He J, Wu H and Zhang Y: Dual loading miR-218 mimics and Temozolomide using $\mathrm{AuCOOH}{ }^{\circledR} \mathrm{FA}-\mathrm{CS}$ drug delivery system: Promising targeted anti-tumor drug delivery system with sequential release functions. J Exp Clin Cancer Res 34: 106, 2015.

370. Xue W, Dahlman JE, Tammela T, Khan OF, Sood S, Dave A, Cai W, Chirino LM, Yang GR, Bronson R, et al: Small RNA combination therapy for lung cancer. Proc Natl Acad Sci USA 111: E3553-E3561, 2014.

371. Nishimura M, Jung EJ, Shah MY, Lu C, Spizzo R, Shimizu M, Han HD, Ivan C, Rossi S, Zhang X, et al: Therapeutic synergy between microRNA and SiRNA in ovarian cancer treatment. Cancer Discov 3: 1302-1315, 2013.

372. Hu X, Li W, Liu G, Wu H, Gao Y, Chen S, He D and Zhang Y: The effect of Bcl-2 siRNA combined with miR-15a oligonucleotides on the growth of Raji cells. Med Oncol 30: 430, 2013. 